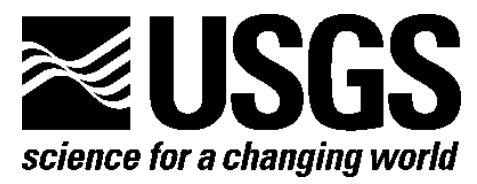

In cooperation with the Oregon Department of Forestry, Elliott State Forest; Oregon Department of Geology and Mineral Industries; and Colorado School of Mines

\title{
Hydrologic Monitoring of a Landslide-Prone Hillslope in the Elliott State Forest, Southern Coast Range, Oregon, 2009-2012
}

By Joel B. Smith, Jonathan W. Godt, Rex L. Baum, Jeffrey A. Coe, William J. Burns, Ning Lu, Michael M. Morse, Basak Sener-Kaya, and Murat Kaya

Open-File Report 2013-1283

U.S. Department of the Interior

U.S. Geological Survey 


\section{U.S. Department of the Interior \\ SALLY JEWELL, Secretary}

\section{U.S. Geological Survey \\ Suzette Kimball, Acting Director}

U.S. Geological Survey, Reston, Virginia: 2014

For more information on the USGS-the Federal source for science about the Earth, its natural and living resources, natural hazards, and the environment-visit http://www.usgs.gov or call 1-888-ASK-USGS

For an overview of USGS information products, including maps, imagery, and publications, visit $h$ ttp://www.usgs.gov/pubprod

To order this and other USGS information products, visit $h$ ttp://store.usgs.gov

Suggested citation:

Smith, J.B., Godt, J.W., Baum, R.L., Coe, J.A., Burns, W.J., Lu, N., Morse, M.M., Sener-Kaya, B., and Kaya, M., 2014, Hydrologic monitoring of a landslide-prone hillslope in the Elliott State Forest, Southern Coast Range, Oregon, 2009-2012: U.S. Geological Survey Open-File Report, 2013-1283, 61 p., http://dx.doi.org/10.3133/ofr20131283.

ISSN 2331-1258 (online)

Any use of trade, product, or firm names is for descriptive purposes only and does not imply endorsement by the U.S. Government.

Although this report is in the public domain, permission must be secured from the individual copyright owners to reproduce any copyrighted material contained within this report. 


\section{Contents}

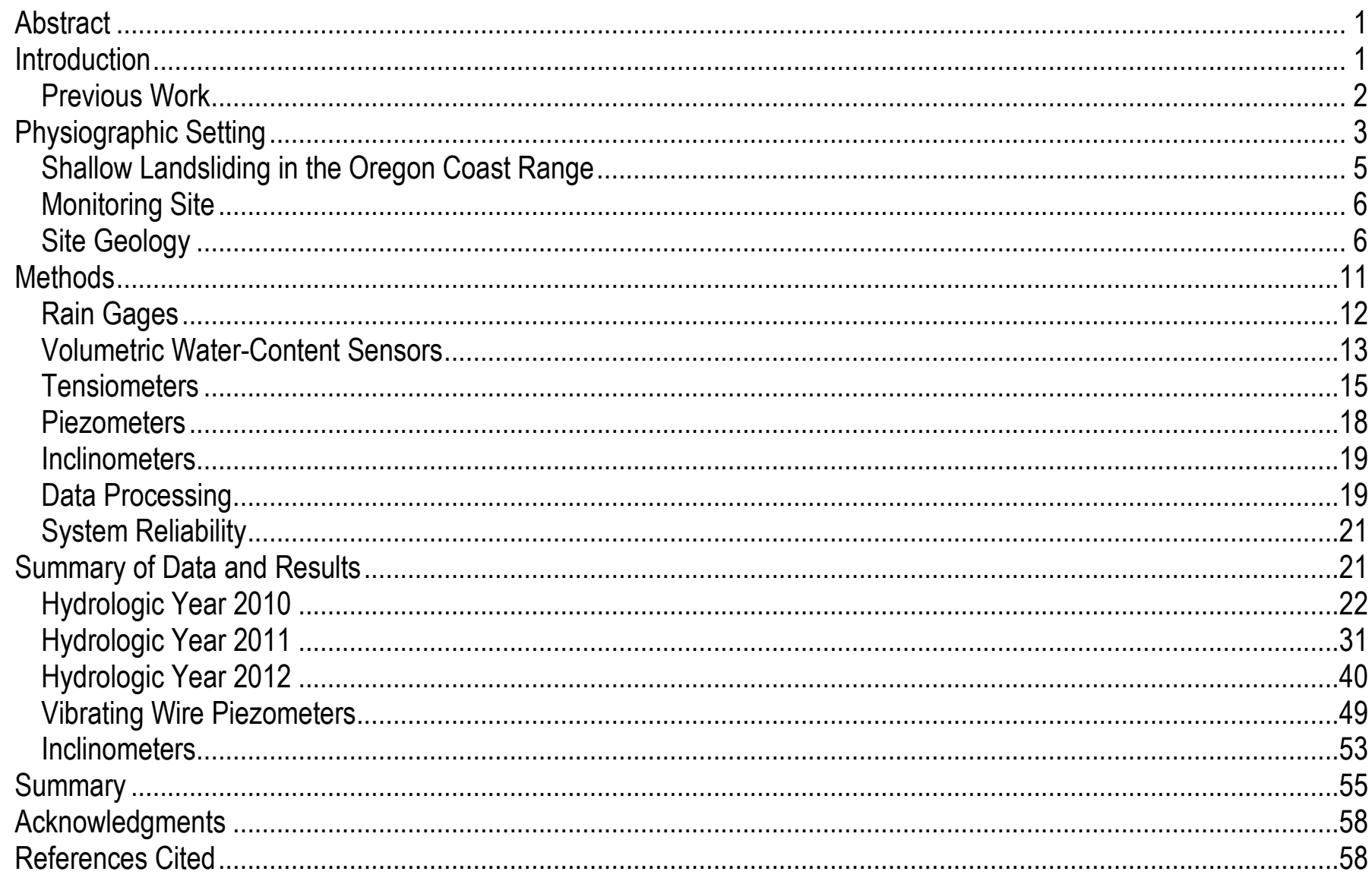

\section{Figures}

Figure 1. Regional map of study area in the Elliott State Forest, Oregon ........................................................ 2

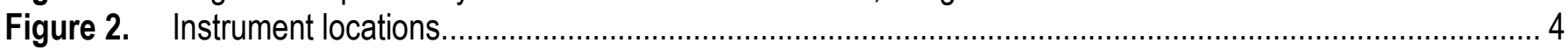

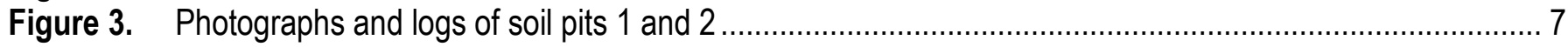

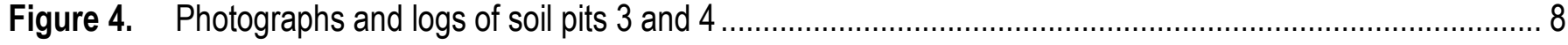

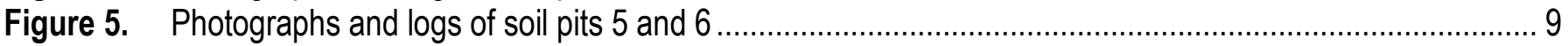

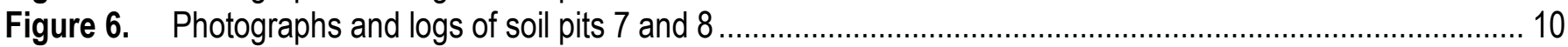

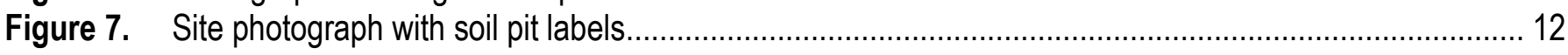

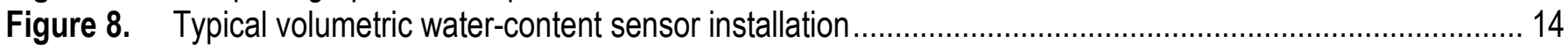

Figure 9. Photograph of typical sensor nest configuration and tensiometer housings. ........................................ 16

Figure 10. Tensiometer installation geometry (protective housing not shown) .............................................. 17

Figure 11. Hourly rainfall $A$, volumetric water content $B$, and pore pressure $C$ at Soil Pit 1 for HY2010 ............. 23

Figure 12. Hourly rainfall $A$, volumetric water content $B$, and pore pressure $C$ at Soil Pit 2 for HY2010 .............. 24

Figure 13. Hourly rainfall $A$, volumetric water content $B$, and pore pressure $C$ at Soil Pit 3 for HY2010 .............. 25

Figure 14. Hourly rainfall $A$, volumetric water content $B$, and pore pressure $C$ at Soil Pit 4 for HY2010 .............. 26

Figure 15. Hourly rainfall $A$, volumetric water content $B$, and pore pressure $C$ at Soil Pit 5 for HY2010 ............. 27

Figure 16. Hourly rainfall $A$, volumetric water content $B$, and pore pressure $C$ at Soil Pit 6 for HY2010 .............. 28

Figure 17. Hourly rainfall $A$, volumetric water content $B$, and pore pressure $C$ at Soil Pit 7 for HY2010 .............. 29

Figure 18. Hourly rainfall $A$, volumetric water content $B$, and pore pressure $C$ at Soil Pit 8 for HY2010 .............. 30

Figure 19. Hourly rainfall $A$, volumetric water content $B$, and pore pressure $C$ at Soil Pit 1 for HY2011 .............. 32 
Figure 20. Hourly rainfall $A$, volumetric water content $B$, and pore pressure $C$ at Soil Pit 2 for HY2011 .............. 33

Figure 21. Hourly rainfall $A$, volumetric water content $B$, and pore pressure $C$ at Soil Pit 3 for HY2011 .............. 34

Figure 22. Hourly rainfall $A$, volumetric water content $B$, and pore pressure $C$ at Soil Pit 4 for HY2011 .............. 35

Figure 23. Hourly rainfall $A$, volumetric water content $B$, and pore pressure $C$ at Soil Pit 5 for HY2011 .............. 36

Figure 24. Hourly rainfall $A$, volumetric water content $B$, and pore pressure $C$ at Soil Pit 6 for HY2011 .............. 37

Figure 25. Hourly rainfall $A$, volumetric water content $B$, and pore pressure $C$ at Soil Pit 7 for HY2011 .............. 38

Figure 26. Hourly rainfall $A$, volumetric water content $B$, and pore pressure $C$ at Soil Pit 8 for HY2011 .............. 39

Figure 27. Hourly rainfall $A$, volumetric water content $B$, and pore pressure $C$ at Soil Pit 1 for HY2012 ….......... 41

Figure 28. Hourly rainfall $A$, volumetric water content $B$, and pore pressure $C$ at Soil Pit 2 for HY2012 ….......... 42

Figure 29. Hourly rainfall $A$, volumetric water content $B$, and pore pressure $C$ at Soil Pit 3 for HY2012 ............. 43

Figure 30. Hourly rainfall $A$, volumetric water content $B$, and pore pressure $C$ at Soil Pit 4 for HY2012 .............. 44

Figure 31. Hourly rainfall $A$, volumetric water content $B$, and pore pressure $C$ at Soil Pit 5 for HY2012 ............. 45

Figure 32. Hourly rainfall $A$, volumetric water content $B$, and pore pressure $C$ at Soil Pit 6 for HY2012 …......... 46

Figure 33. Hourly rainfall $A$, volumetric water content $B$, and pore pressure $C$ at Soil Pit 7 for HY2012 ….......... 47

Figure 34. Hourly rainfall $A$, volumetric water content $B$, and pore pressure $C$ at Soil Pit 8 for HY2012 …......... 48

Figure 35. Hourly rainfall and pore pressure along basin axis for HY2010 …………………........................ 50

Figure 36. Hourly rainfall and pore pressure along basin axis for HY2011 .................................................... 51

Figure 37. Hourly rainfall and pore pressure along basin axis for HY2012 …............................................. 52

Figure 38. Inclinometer tilt measurement plots from A, SP1; B, SP2; and C, SP7 ....................................... 54

Figure 39. Boxplots showing seasonal and topographic variation in pore pressure/soil suction measurements... 56

Figure 40. Boxplots showing seasonal and topographic volumetric water content variation................................57

\section{Tables}

Table 1. Locations and depths of volumetric water content sensors.............................................................. 15

Table 2. Tensiometer installation information. See figure 10 for installation geometry ....................................... 18

Table 3. Table showing location and depth of vibrating-wire piezometers ...................................................... 19

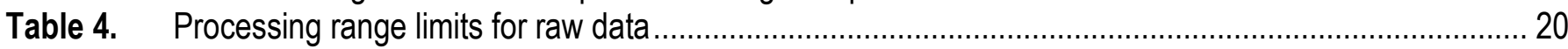




\section{Conversion Factors}

Vertical coordinates are heights above mean sea level (meters) in the North American Vertical Datum of 1988 (NAVD 88). Horizontal coordinates are Universal Transverse Mercator, Zone 10, meters.

SI to Inch/Pound

\begin{tabular}{lcl}
\hline \multicolumn{1}{c}{ Multiply } & By & \multicolumn{1}{l}{ To obtain } \\
\hline centimeter $(\mathrm{cm})$ & 0.3937 & inch (in.) \\
millimeter $(\mathrm{mm})$ & 0.03937 & inch (in.) \\
meter $(\mathrm{m})$ & 3.281 & foot $(\mathrm{ft})$ \\
kilometer $(\mathrm{km})$ & 0.5400 & mile, nautical $(\mathrm{nmi})$ \\
\hline & Area & \\
\hline square meter $\left(\mathrm{m}^{2}\right)$ & 0.0002471 & acre \\
square kilometer $\left(\mathrm{km}^{2}\right)$ & 247.1 & acre \\
square meter $\left(\mathrm{m}^{2}\right)$ & 10.76 & square foot $\left(\mathrm{ft}^{2}\right)$ \\
square centimeter $\left(\mathrm{cm}^{2}\right)$ & 0.1550 & square inch $\left(\mathrm{ft}^{2}\right)$ \\
square kilometer $\left(\mathrm{km}^{2}\right)$ & 0.3861 & square mile $\left(\mathrm{mi}{ }^{2}\right)$ \\
\hline kilometer $(\mathrm{km})$ & 0.6214 & mile $($ mi) \\
\hline & Pressure & \\
\hline kilopascal $(\mathrm{kPa})$ & 0.009869 & atmosphere, standard $(\mathrm{atm})$ \\
kilopascal $(\mathrm{kPa})$ & 0.01 & bar \\
kilopascal $(\mathrm{kPa})$ & 0.2961 & inch of mercury at $60^{\circ} \mathrm{F}(\mathrm{in} \mathrm{Hg})$ \\
kilopascal $(\mathrm{kPa})$ & 0.1450 & pound-force per inch $(\mathrm{lbf} / \mathrm{in})$ \\
kilopascal $(\mathrm{kPa})$ & 20.88 & pound per square foot $\left(\mathrm{lb} / \mathrm{ft}^{2}\right)$ \\
kilopascal $(\mathrm{kPa})$ & 0.1450 & pound per square inch $\left(\mathrm{lb} / \mathrm{ft}^{2}\right)$ \\
\hline & Hydraulic conductivity & \\
\hline centimeter per hour $\left(\mathrm{cm}^{2} / \mathrm{hr}\right)$ & 0.03281 & foot per hour $(\mathrm{ft} / \mathrm{hr})$ \\
\hline
\end{tabular}

Temperature in degrees Celsius $\left({ }^{\circ} \mathrm{C}\right)$ may be converted to degrees Fahrenheit $\left({ }^{\circ} \mathrm{F}\right)$ as follows:

${ }^{\circ} \mathrm{F}=\left(1.8 \times{ }^{\circ} \mathrm{C}\right)+32$ 


\title{
Hydrologic Monitoring of Landslide-Prone Hillslopes in the Elliott State Forest, Southern Coast Range, Oregon, 2009-2012
}

By Joel B. Smith, Jonathan W. Godt, Rex L. Baum, Jeffrey A. Coe, William J. Burns, Ning Lu, Michael M. Morse, Basak Sener-Kaya, and Murat Kaya

\begin{abstract}
The Oregon Coast Range is dissected by numerous unchanneled headwater basins, which can generate shallow landslides and debris flows during heavy or prolonged rainfall. An automated monitoring system was installed in an unchanneled headwater basin to measure rainfall, volumetric water content, groundwater temperature, and pore pressures at 15-minute intervals. The purpose of this report is to describe and present the methods used for the monitoring as well as the preliminary data collected during the period from 2009 to 2012. Observations show a pronounced seasonal variation in volumetric water content and pore pressures. Increases in pore pressures and volumetric water content from dry-season values begin with the onset of the rainy season in the fall (typically early to mid October). High water contents and pore pressures tend to persist throughout the rainy season, which typically ends in May. Heavy or prolonged rainfall during the wet season that falls on already moist soils often generates positive pore pressures that are observed in the deeper instruments. These data provide a record of the basin's hydrologic response to rainfall and provide a foundation for understanding the conditions that lead to landslide and debris-flow occurrence.
\end{abstract}

\section{Introduction}

The steep hillslopes and heavy wet-season precipitation of the Oregon Coast Range (OCR) make it an ideal location for monitoring hydrologic conditions that trigger shallow landslides. The periodic removal of trees in areas managed for industrial forestry also tends to promote slope instability (for example, Schmidt and others, 2001; Roering and others, 2003). In addition, the interplay between tectonic uplift and erosion (Reneau and Dietrich, 1991; Personius, 1995; Kelsey and others, 1996; Heimsath and others, 2001) has made the area a focus of landslide study.

During July 2009, the U.S. Geological Survey (USGS), in cooperation with the Oregon Department of Forestry, Oregon Department of Geology and Mineral Industries (DOGAMI), and the Colorado School of Mines, began installation of a system to monitor precipitation and shallow hillslope hydrologic conditions at a small basin in the Elliott State Forest (fig. 1) to improve our understanding of the conditions that initiate shallow landslides. Quantification of these conditions should help to clarify the roles of antecedent soil moisture conditions and rainfall intensity and duration on landslide initiation and provide observations to test regional and site-specific hydrologic and slope-stability models. 


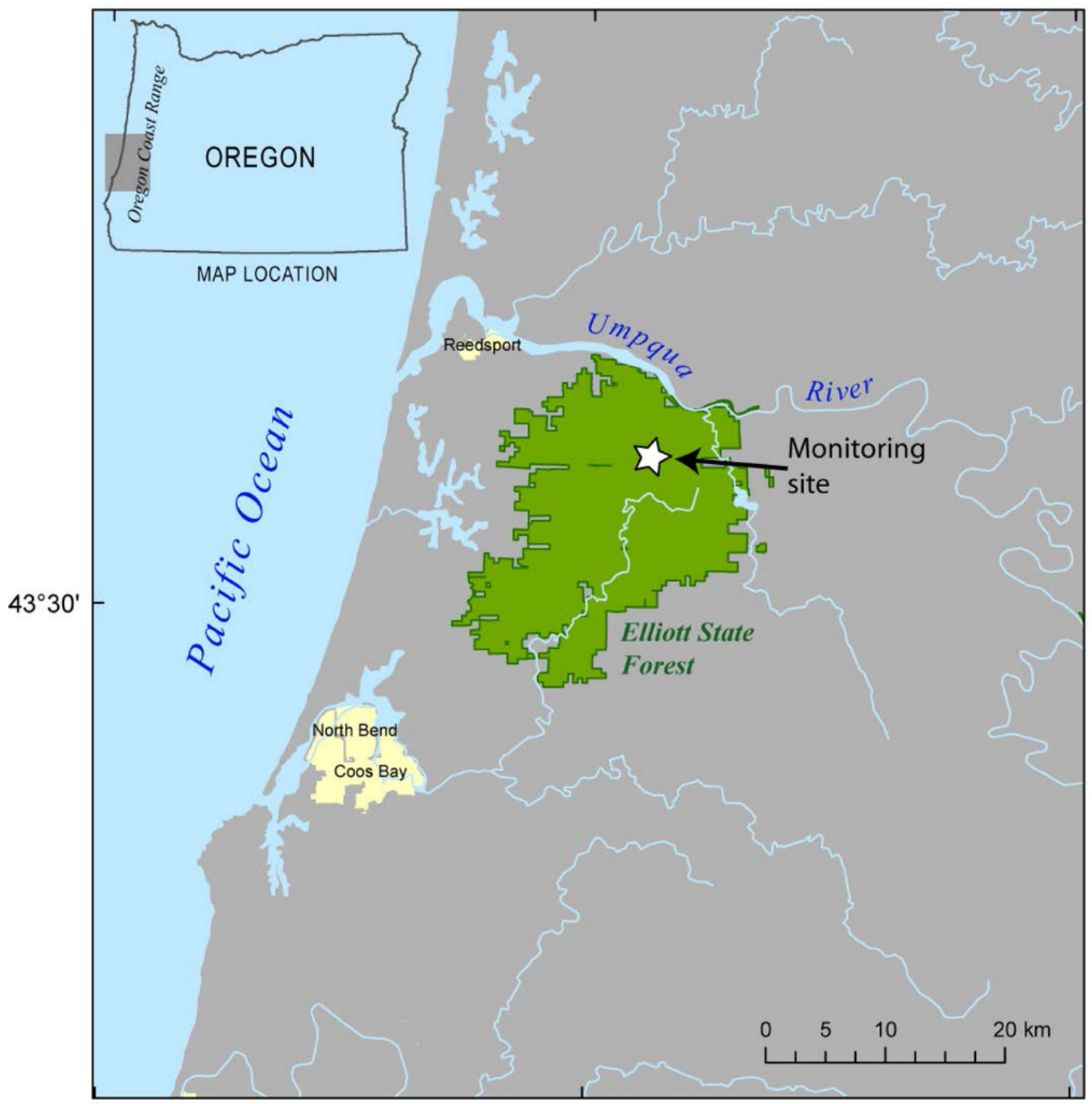

Figure 1. Regional map of study area in the Elliott State Forest, Oregon.

\section{Previous Work}

Monitoring the hydrological response to natural and artificial rainfall has provided valuable insight into the water content and pore-pressure conditions that lead to shallow landslide occurrence (for example, Reid and others, 2008). Pierson (1980) monitored piezometric head within three unchanneled 
headwater basins located in the Perkins Creek watershed in the Northern OCR in order to isolate the factors controlling pore-pressure variation during and following rainstorms. Pierson concluded that while pressure variation was predominantly controlled by rainfall duration and intensity, catchment area, and antecedent soil-moisture conditions, measurements of these factors alone were insufficient to correlate pore-pressure response between different catchments under similar conditions.

Torres and others (1998) conducted field experiments at an irrigated, unchanneled headwater basin in the OCR in order to investigate pore-water propagation through unsaturated soil. They concluded that the basin's hydrologic response to precipitation was dictated by unsaturated zone dynamics and the unsaturated hydrologic properties of the basin materials. Torres and others found that once a soil profile reached a homogeneous near-zero pressure head driven by persistent light rain, a sudden increase in rainfall intensity created large changes in hydraulic conductivity (while maintaining a near constant pressure head), which released large quantities of water stored in the soil into the underlying saturated zone. A report of a debris flow that was initiated during experiments at the catchment can be found in Montgomery and others (2009). They attributed the initiation of the shallow landslide to water that exfiltrated from the fractured bedrock into the overlying soil.

Baum and others (2005) monitored shallow subsurface hydrologic conditions at two coastal bluffs along the Puget Sound in the Seattle, Washington, area. Their monitoring recorded the hydrologic conditions leading up to a shallow landslide in January, 2006. Using these data, Godt and others (2009) showed that shallow landslide initiation on the steep $\left(45^{\circ}\right)$ hillslope at one of the sites occurred without the recorded development of positive pore pressures.

In this report, we describe the geologic and climatic setting of the monitored basin, the types of instruments that were installed, and the data collected from 2009 to 2012 . Throughout the remainder of this report, we refer to the monitored basin as the Knife Ridge Basin because of its proximity to a prominent north-south trending ridge called Knife Ridge.

\section{Physiographic Setting}

The OCR trends north-south along the west part of the state of Oregon for approximately 320 $\mathrm{km}$ and is approximately 50-65 kilometers $(\mathrm{km})$ wide. The climate of the OCR is strongly influenced by the Pacific Ocean. The resultant weather consists of generally mild temperatures with a rainy period that extends from October to May and a drier period from June through September. The annual precipitation in the Elliott State Forest ranges from 1,500 millimeters ( $\mathrm{mm}$ ) to 3,000 mm, depending on elevation, with greater precipitation generally occurring at higher elevations (Andrus and others, 2003).

The OCR is geographically split into northern, central, and southern segments by rivers that flow into the Pacific Ocean. The northern segment is bounded on the north and south by the Columbia and Salmon Rivers, respectively, the central segment by the Salmon River in the north and Umpqua River in the south, and the southern segment by the Umpqua River in the north and Coquille River to the south. The Elliott State Forest is located in the southern OCR.

The OCR is located in the forearc region of the Cascadia subduction zone where the North American plate overlies the subducting Juan de Fuca plate. The OCR is an accretionary wedge created by marine sediments scraped off the subducting Juan de Fuca plate and by sediments deposited within forearc basins created by deformation of the accretionary wedge (Beaulieu and Hughes, 1975; Heller and Dickinson, 1985). Reneau and Dietrich (1991) suggest that the range formation is in equilibrium; that is, the rate of tectonic uplift is approximately the same as the rate of lowering driven by erosion, barring land disturbance.

The characteristic hillslope geometry in the OCR can be described as a sequence of convex and concave parabolic shapes. A set of two convex curves joined by a concavity, projected perpendicularly 
downward from the ridgeline, constitutes a basin. The basin contains three distinct features: nose slopes (shared with adjacent basins), side slopes, and axis. In general, the nose slope has a convex shape in both the downslope and cross-slope orientation. The nose slope's cross-slope convexity results in divergent flow and slope wash. The side slope between the nose slope and the basin axis has a planar shape that is oriented roughly tangent to the radii formed by the convex nose slope and concave basin axis (fig. 2). The basin axis, between nose slopes, generally has a concave shape in cross-slope and downslope (accompanied by buried vertical steps) orientations. This concave shape results in an effective drainageway where runoff and sediment from adjacent nose and side slopes converge, causing sediments to accumulate. The slope concavities along the basin axis are otherwise known as unchanneled (or channeled in the event of a landslide or debris flow) headwater basins, bedrock hollows (Dietrich and Dunne, 1978), or zero-order basins (Tsukamoto and others, 1982), and these locations are generally regarded as the primary source area for shallow landslides and debris flows (Hack and Goodlett, 1960; Swanston, 1970; Pierson, 1980).

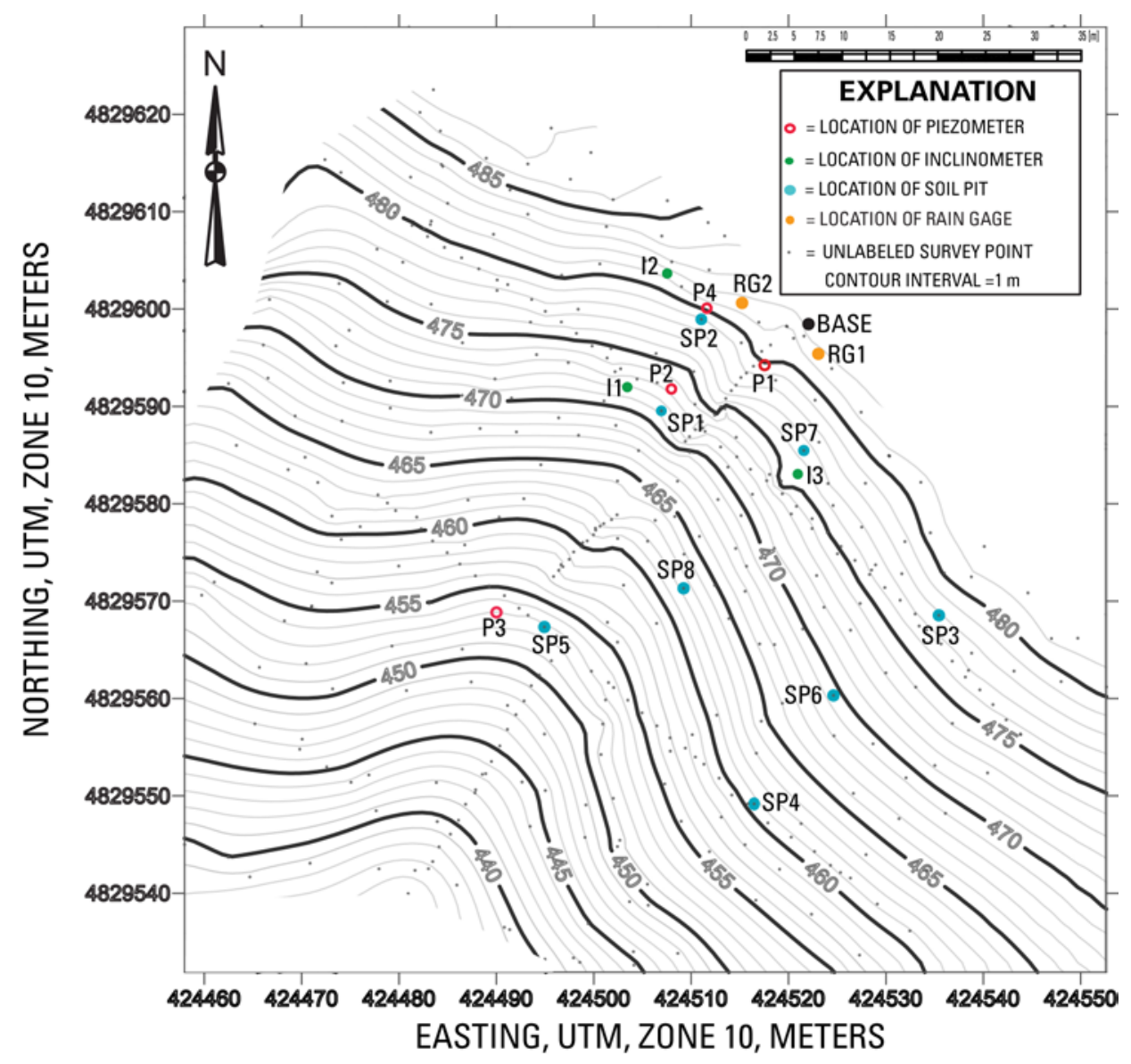

Figure 2. Instrument locations (UTM, Universal Transverse Mercator; m, meters).

In the OCR, two distinct gravitational transport processes move sediment to basin axes where it accumulates, locally increasing the probability of shallow landslides and debris flows. Processes that contribute material to basin axes are either discrete slope failures (landslides), or so-called diffusive processes (Roering and others, 1999). Slope failure processes, such as landslides, generally increase in frequency at greater slope angles. Diffusive processes are those that continuously move soil downslope 
and include rainsplash, soil creep, tree throw, frost heave, and bioturbation due to animal burrowing, notably the prevalent Aplodontia rufa (Coast Range mountain beaver) (Beier, 1989; Heimsath and others, 2001). Roering and others (1999) state that diffusive sediment transport has a proportional, nonlinear relationship to slope angle.

Most of the downslope movement of Coast Range soil is attributed to these gravitational processes (Lane, 1987), as opposed to erosion. The average soil transport rate for a forearc range such as the OCR has been estimated at values ranging from of $0.5 \mathrm{~mm}$ per year $\left(\mathrm{yr}^{-1}\right.$ ) to $2.0 \mathrm{~mm} \mathrm{yr}^{-1}$ (Young and Saunders, 1986; Roering and others, 1999). These diffusive processes create a spatial distribution of soil depth that is thinnest at the nose slope and becomes progressively thicker downslope where it collects in basin axes.

\section{Shallow Landsliding in the Oregon Coast Range}

Previous research shows that high-intensity-long-duration rainfall seems to control initiation of landslides in the OCR (for example, Wiley, 2000; Montgomery and others, 2009). Patric and Swanston (1968) suggested that although topography, geology, and soil factors predispose certain locations to landslides, slide timing is directly linked to rainfall. For example, the storms of 1996 (in February and November) with mean rainfall intensities of $4.9 \mathrm{~mm} /$ hour (hr) $(71 \mathrm{hr}$ duration) and $3.4 \mathrm{~mm} / \mathrm{hr}(39 \mathrm{hr}$ duration), respectively, initiated numerous landslides and debris flows in the region (Robison and others, 1999; Wiley, 2000; Montgomery and others, 2009; Coe and others, 2011).

Wiley (2000) identified three measures useful for identifying rainfall conditions that initiate shallow landslides: (1) mean December rainfall, (2) mean annual precipitation, and (3) rainy-day normal precipitation. These values empirically quantify the amount of water hillslopes are capable of holding before failure, in which each value represents a maxima (threshold) above which the likelihood of landslides and debris flows are much greater. Before the threshold of moisture can be met antecedent conditions must be satisfied, that is the soil must be moistened to a point that any additional water will result in gravitational drainage (Wiley, 2000). A strong indication of threshold exceedance is a rise in groundwater level (positive pore pressure) after the storage capacity of the soil has been reached. Soil water capacity in western Oregon is typically 1 to $12 \mathrm{~mm}$ of water per 2.5 centimeters $(\mathrm{cm})$ of soil (Johnson and others, 1994).

Substantial effort has been expended to understand the effects of forest timber harvest on slope stability, especially from a watershed-management perspective (for example, Brown and Krygier, 1971; Beschta, 1978). Swanson and others (1981) estimated that erosion by debris flows in clear-cut areas is greater by a factor of four over that in undisturbed areas. In addition, Swanson and others (1981) estimated that road construction for timber access can increase debris-flow erosion by as much as a factor of 120 over that of an undisturbed area.

Efforts to quantify the effects of timber harvest on slope stability have focused on two topics: (1) the effects of the death and decay of tree roots on the material strength of the soil-tree root composite (for example, Burroughs and Thomas, 1977; Schmidt and others, 2001; Roering and others, 2003), and (2) the influence of the removal of the tree canopy on the intensity and amount of rainfall reaching the ground and the resultant effects on infiltration and groundwater response (Keim and Skaugset, 2003). Both effects tend to increase the susceptibility of slopes to landslides. As tree roots decay their tensile strength is reduced. Schmidt and others (2001) found that this "root cohesion" can reach up to approximately 100 kilopascals $(\mathrm{kPa})$ in natural areas and is reduced to approximately $10 \mathrm{kPa}$ in clear-cut areas. This reduction in tensile strength, which occurs over the course of several years as the tree roots decay, reduces the overall strength of the tree root-soil composite. The reduction of root-soil-composite strength leads to greater landslide potential in clear-cut areas. Harvesting trees also removes the 
attenuating effects of the tree canopy on rainfall infiltration. Rainfall readily infiltrates into the soil in clear-cut areas, in contrast to forested areas where rainfall intensities at ground level are damped by 2152 percent in young stands and 31-83 percent in mature stands. Keim and Skaugset (2003) also found that the delay to peak rainfall intensity beneath the tree canopy was up to 2 minutes (min) in young stands and up to 4 min in old-growth stands.

\section{Monitoring Site}

The Knife Ridge monitoring site is located in the Elliott State Forest in the southern segment of the Coast Range. The site is located in a southwest-facing unchanneled headwater basin about $29 \mathrm{~km}$ southeast of the city of Reedsport (fig. 1). The total area of the basin (Knife Ridge to Knife River between nose slopes surrounding the unchanneled basin) is about 18,000 square meters $\left(\mathrm{m}^{2}\right)$. The monitored area of the basin is about $4,350 \mathrm{~m}^{2}$. This basin was chosen for this study because it had been recently logged, the hillslopes are steep (greater than $30^{\circ}$ ) - but not so steep as to make instrument installation impossible - and vehicle access to the upper catchment divide is available. A prototype monitoring system was installed in 2006, but the data from this system were inconsistently acquired and, therefore, not included in this report.

Founded in 1930, the Elliott State Forest covers a land area of 376.4 square kilometers and was Oregon's first State Forest. The Forest is owned by the State Land Board and 91 percent of its land area is Common School Fund lands. Common School Fund lands are managed for timber harvest and profits are used to support the state's K-12 public education system.

The basin and surrounding area was clear-cut logged around 2005 and replanted shortly thereafter. As of 2012, understory vegetation and woody debris from logging operations covered the ground surface. The replanted Douglas fir (Pseudotsuga menzeisii) trees, standing 2-3 meters (m) tall, had not yet shaded the Pacific rhododendron (Rhododendron macrophyllum), sword fern (Polystichum munitum), and vine maple (acer circinatum) understory vegetation.

\section{Site Geology}

The monitored basin is underlain by the middle Eocene Tyee Formation (Baldwin, 1961; Heller and Dickinson, 1985; Molenaar, 1985; Wells and others, 2000). The Tyee Formation comprises marine sandstone (around 1,200-1,500 m thick) with interbedded layers (average $13.5 \mathrm{~m}$ thick) of siltstone (Niem and Niem, 1990).

Most of the bedrock in the Knife Ridge Basin is obscured by colluvial and residual soils (Lane, 1987). The soil is a gravel to clay loam mixture of the Preacher-Bohannon-Blachly complex derived from sandstone colluvium (Johnson and others, 1994; Soil Survey Staff, 2013) and is well-drained, with low density and non-plastic fines. The average soil depth for the Preacher-Bohannon-Blachly complex is $0.9 \mathrm{~m}$ to $2.1 \mathrm{~m}$. Similar soils have an internal friction angle of approximately $31^{\circ}$ under drainedsaturated conditions; the internal friction angle increases to $40.5^{\circ}$ when soils are dry (Harr and Yee, 1975; Bransom, 1990). The soil's saturated hydraulic conductivity is moderately high to high, ranging from $1.5-15 \mathrm{~cm} / \mathrm{hr}$ (Soil Survey Staff, 2013).

A general soil profile of the Knife Ridge site consists of an organic layer composed of forest litter or duff that is at most a few tens of centimeters thick underlain by a dark-colored sandy soil that may extend about a meter below the ground surface. Below this layer typically lies a horizon that is typically lighter in color and contains an increasingly large fraction of cobbles and pebbles derived from the underlying bedrock. At greater depths (roughly $0.6 \mathrm{~m}$ to more than $2.0 \mathrm{~m}$ ) a tan to reddish-tan weathered sandstone is found. Figures 2 through 6 provide locations, photographs, and descriptions of 
the eight soil pits that were dug by hand for the emplacement of volumetric water-content sensors described in the following sections.
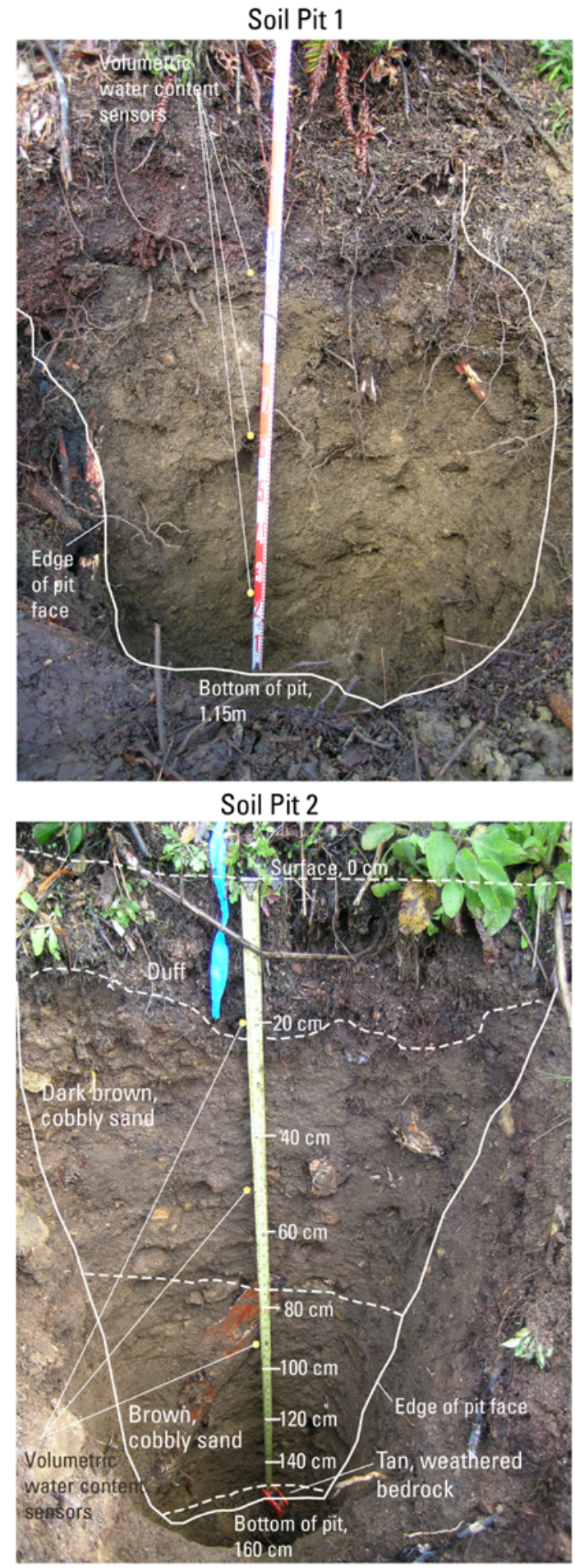

\section{$0-23 \mathrm{~cm}$ Duff}

23-115 $\mathrm{cm}$, brown cobbly sand, slightly sticky, dry = loose friable, forms a ribbon, but doesn't deform, ribbon forms easier using sample from bottom of pit suggesting possible increase in fines downward, roots extend to bottom of pit, but decrease in size and abundance downward from visual estimation, mean root diameter $=2 \mathrm{~mm}$, max. root diameter $=12 \mathrm{~mm}$, wet Munsell color $=$ 75YR 3/3-3/2, mean clast size $=5 \mathrm{~cm}$, max. clast size $=20 \mathrm{~cm}, 15 \%$ clasts

Volumetric water content sensors installed at 20,50, and $125 \mathrm{~cm}$.

$0-23 \mathrm{~cm}$, black duff

23-75 $\mathrm{cm}$, dark brown to black cobbly sand, $\sim 10 \%$ tan clasts, roots up to $5 \mathrm{~cm}$ diameter

$75-155 \mathrm{~cm}$, brown cobbly sand, $40 \%$ tan sandstone clasts, distinct color contrast with overlying unit, possibly more fines than overlying unit as soil is slightly sticky

$155-160 \mathrm{~cm}$, tan weathered sandstone

Volumetric water content sensors installed at 20,50, and $93 \mathrm{~cm}$.

Figure 3. Photographs and logs of soil pits 1 and 2. Some soil description nomenclature from Birkeland (1999). (cm, centimeters; $\mathrm{m}$, meters; $\mathrm{mm}$, millimeters) 


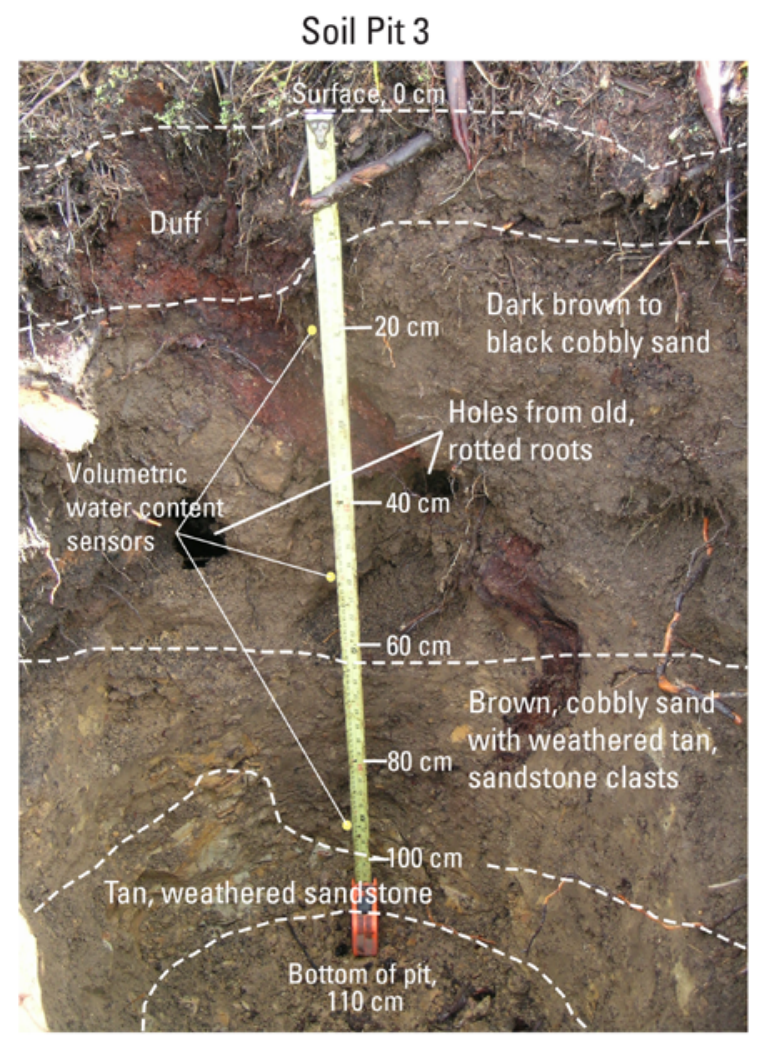

Soil Pit 4

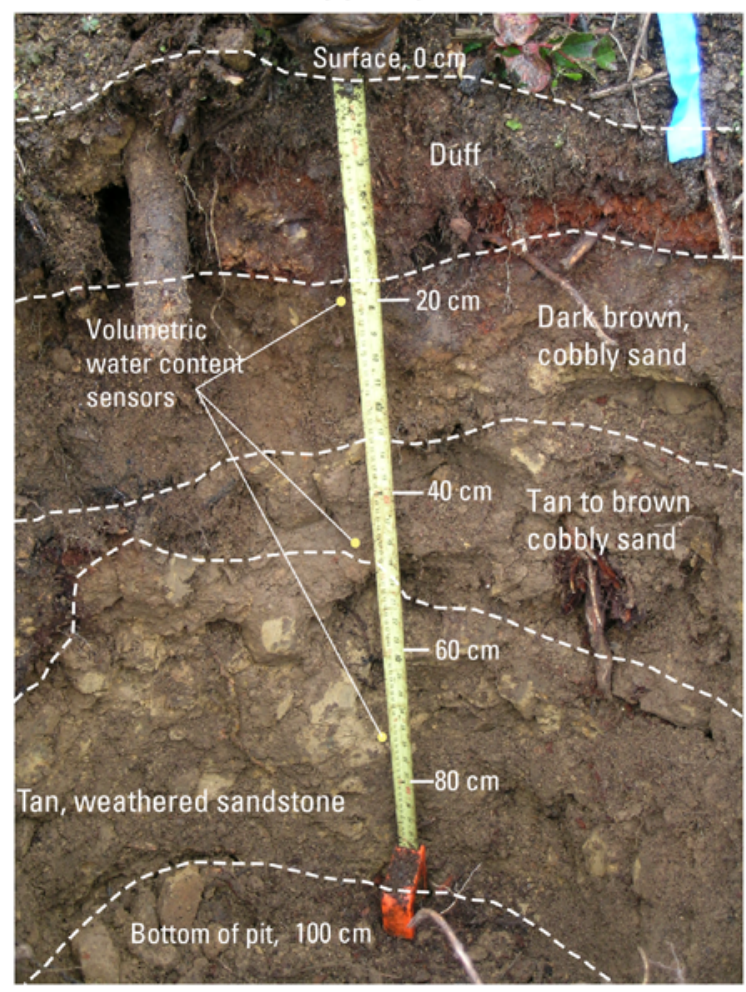

0-10 cm, black duff, with roots

10-62 cm, dark brown to black cobbly sand, $\sim 5 \%$ tan clasts, $5 \mathrm{~cm}$ diameter macro pore, rotting and modern roots

$62-100 \mathrm{~cm}$, brown cobbly sand with $\sim 30 \%$ weathered clasts, slightly sticky

100-110 cm, tan weathered sandstone, some reddish tan color

Volumetric water content sensors installed at 20,50, and $94 \mathrm{~cm}$.

$0-17 \mathrm{~cm}$, duff with $5 \mathrm{~cm}$ diameter dead root

$17-33 \mathrm{~cm}$, dark brown, cobbly sand, $\sim 10 \%$ clasts, modern small roots

$33-50 \mathrm{~cm}$, tan to brown cobbly sand, $\sim 50 \%$ clasts

50-100 cm, tan weathered sandstone

Volumetric water content sensors installed at 20,50, and $75 \mathrm{~cm}$.

Figure 4. Photographs and logs of soil pits 3 and 4. Some soil description nomenclature from Birkeland (1999). (cm, centimeters; $\mathrm{m}$, meters; $\mathrm{mm}$, millimeters) 

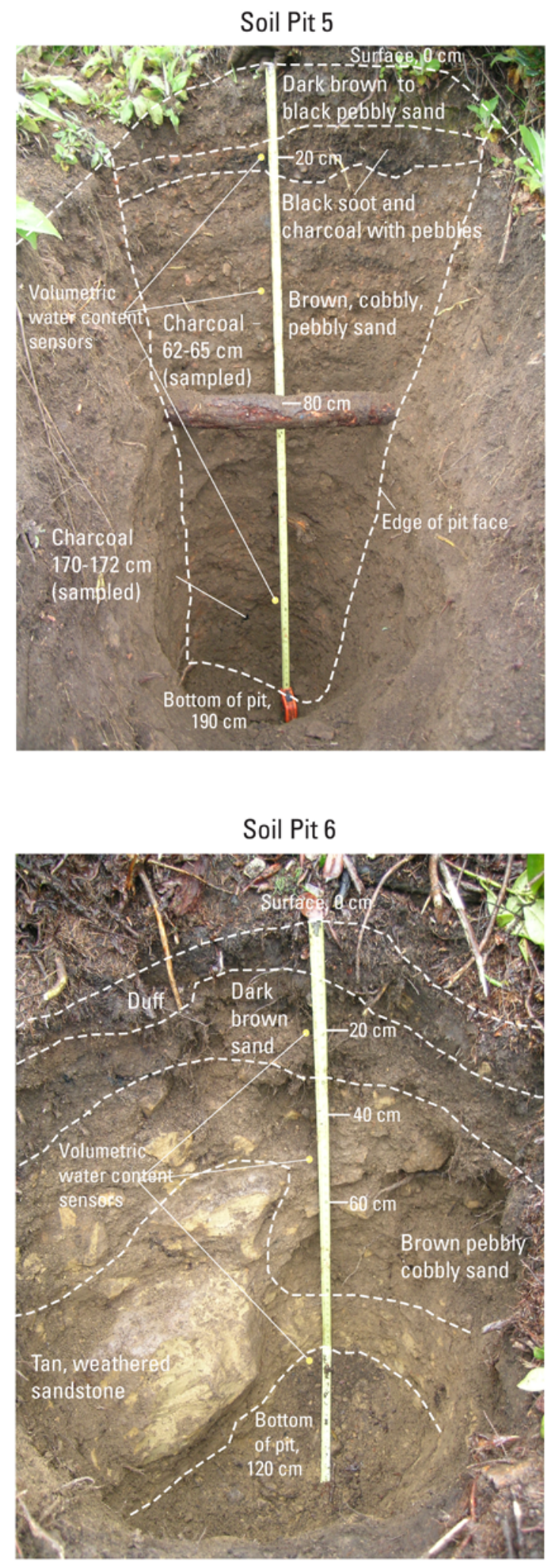

0-15 cm, dark brown to black pebbly sand

$15-25 \mathrm{~cm}$, black charcoal and soot layer with pebbles

$25-120 \mathrm{~cm}$, brown cobbly pebbly sand, $40 \%$ tan to red sandstone clasts, charcoal present, uniform texture with randomly oriented clasts

$120-190 \mathrm{~cm}$, same as unit above except $60 \%$ clasts and large charcoal chucks are present

Volumetric water content sensors installed at 20,50, and $160 \mathrm{~cm}$.
$0-10 \mathrm{~cm}$, duff

10-30 cm, dark brown sand, organic rich, 5\% sandstone clasts

30-90 cm, brown pebbly cobbly sand, $\sim 40 \%$ cobbles, $5 \%$ pebbles, tan sandstone clasts

$90-120 \mathrm{~cm}$, tan weathered sandstone

Volumetric water content sensors installed at 20, 50, and $90 \mathrm{~cm}$.

Figure 5. Photographs and logs of soil pits 5 and 6 . Some soil description nomenclature from Birkeland (1999). (cm, centimeters; $\mathrm{m}$, meters; $\mathrm{mm}$, millimeters) 


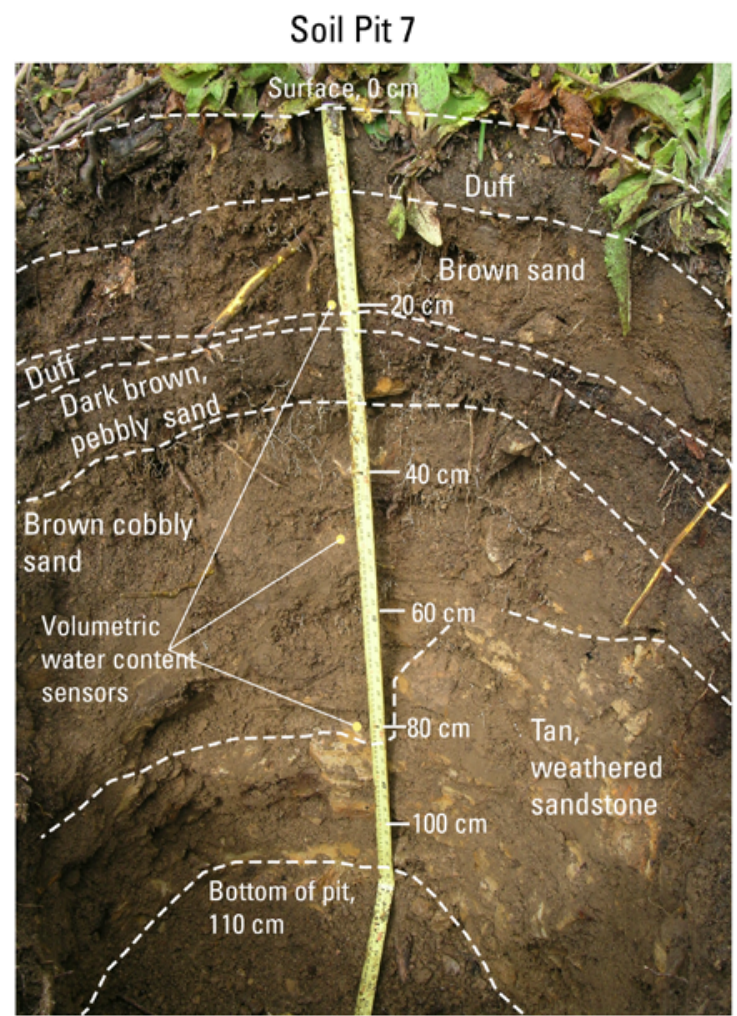

Soil Pit 8

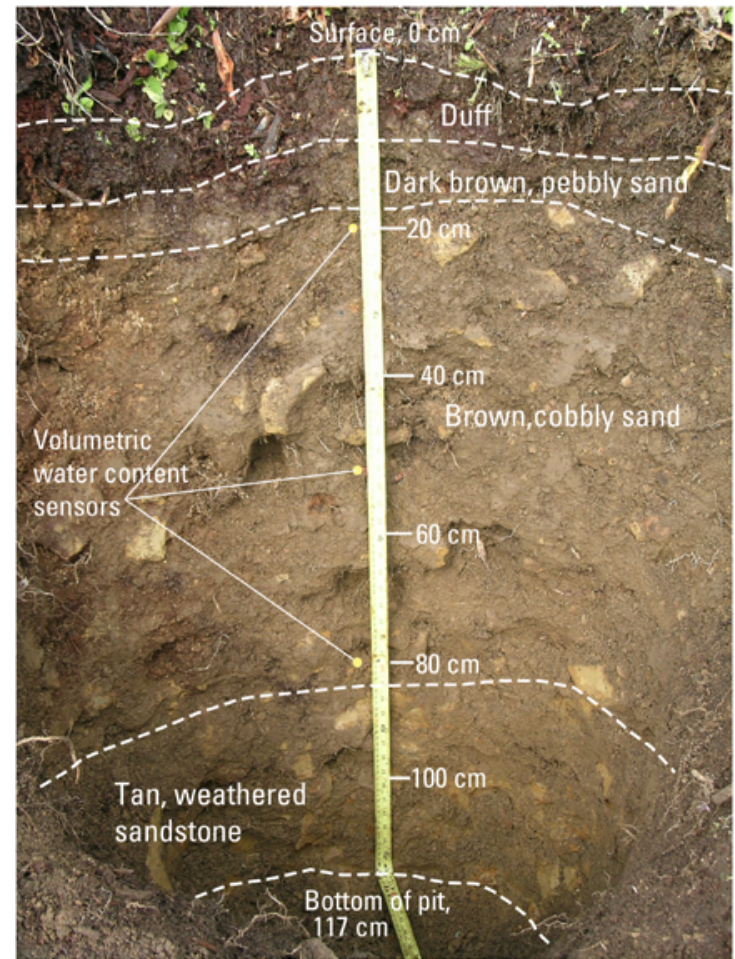

$0-8 \mathrm{~cm}$, duff

8-21 cm, brown sand, $\sim 5 \%$ clasts

21-22 cm, duff, may represent a buried surface

22-31 cm dark brown, pebbly sand, organic rich

$31-80 \mathrm{~cm}$, brown cobbly sand, $\sim 30 \%$ tan cobbles

80 to $110 \mathrm{~cm}$, tan weathered sandstone

Volumetric water content sensors installed at 20,50, and $80 \mathrm{~cm}$.
0-10 cm, duff

10-17 cm, dark brown pebbly sand

17-85 cm, brown cobbly sand, slightly sticky, $\sim 30 \%$ tan to reddish brown cobbles, modern roots up to $1 \mathrm{~cm}$ diameter

$85-117 \mathrm{~cm}$, tan weathered sandstone

Volumetric water content sensors installed at 20,50, and $80 \mathrm{~cm}$.

Figure 6. Photographs and logs of soil pits 7 and 8 . Some soil description nomenclature from Birkeland (1999). $(\mathrm{cm}$, centimeters; $\mathrm{m}$, meters; $\mathrm{mm}$, millimeters) 


\section{Methods}

The data-collection system installed at the Knife Ridge site is designed to collect and deliver data in near-real time and consists primarily of geotechnical and hydrologic monitoring instrumentation controlled by a central data logger (Campbell Scientific, Inc. CR1000). The site is powered using a 48watt solar panel, two 100-amp-hour deep-cycle batteries, and a 15-amp solar charge controller (Morningstar ProStar-15). The system reads and records sensor data every $15 \mathrm{~min}$, and the data are telemetered using a VHF Meteor Burst radio (Meteor Communications Corporation MCC-545B Packet Data Radio). The radio transmits data to a SNOwpack TELemety (SNOTEL) (Schaefer, 1990) master station near Boise, Idaho, operated by the United States Department of Agriculture's National Resources Conservation Service (NRCS). Data are made available via an NRCS FTP site-once the data are online, automated computers in the USGS offices in Golden, Colorado (Colo.) download, sort, archive, and graph the data. Finally, data plots are copied to the USGS Landslide Hazards web site for access by the general public.

The monitoring system consists of rain gages located near the ground surface and instruments to measure soil-water conditions buried in and around eight soil pits (figs. 2-7). The eight soil pits (SP\#) are distributed in three topographically based zones on the slope. Three pits are located along the basin axis (SP2, SP1, and SP5), three pits are located on the basin's eastern nose slope (SP3, SP6, and SP4), and two pits are located on the basin's eastern side slope (SP7, SP8). Each soil pit contains three volumetric water-content sensors in a vertical profile. Three tensiometers (shallow, mid, deep) are located in boreholes that were advanced near the soil pits. The boreholes were oriented slope normal and the porous stones (sensing tips) of the tensiometers were placed at depths to form an approximately vertical array. 


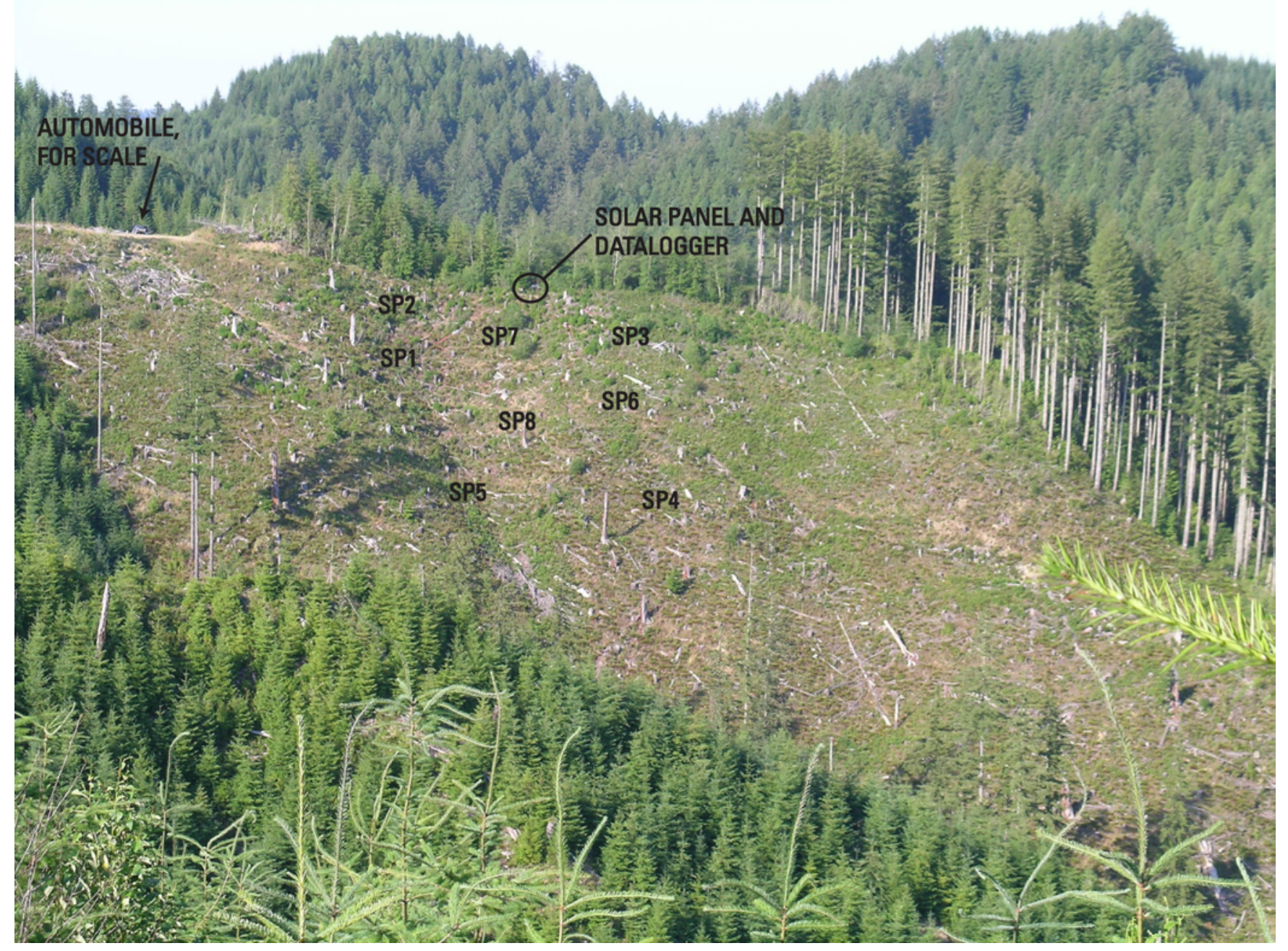

Figure 7. Site photograph with soil pit labels.

Three piezometers were installed in boreholes cased with PVC tubing near each of the soil pits along the axis of the basin (P1, P2, and P3, fig. 2). An additional piezometer (P4, fig. 2) was located about one meter above the ground surface in an enclosure open to the atmosphere to measure barometric pressure. Three inclinometers (I1, I2, I3, fig. 2) were installed in cased boreholes near SP1, SP2, and SP7.

\section{Rain Gages}

The site is equipped with two "tipping bucket" rain gages (Hydrological Services Pty. Ltd. model TB4, fig 2: RG1, RG2). The gages are mounted approximately $1 \mathrm{~m}$ above the ground surface on tree stumps. The gage has a $200 \mathrm{~mm}$ (7.87 inch [in]) primary catch orifice that funnels precipitation to one of two internal buckets that, when filled with rainfall, tip to activate a reed switch. Each switch closure is recorded by the data logger and signifies $0.254 \mathrm{~mm}(0.01 \mathrm{in})$ of rainfall or snowmelt. The dual precipitation gage arrangement provides redundancy in case of gage failure. Dense vegetation nearby necessitates regular cleaning of the catch orifices. 


\section{Volumetric Water-Content Sensors}

The volumetric water-content sensors (Decagon Devices EC-5, figs. 8 and 9) use a capacitance/frequency domain technology to measure the dielectric constant of the soil over a volume of about 0.18 liters (L). These dielectric measurements are related to volumetric water content using an empirical calibration curve (Kizito and others, 2008) that provides about 2 percent error in a range of mineral soils. Figure 8 shows a typical installation in which the sensors were placed in a vertical profile at varying depths, in the uphill face of a 1-m deep pit. The sensors were installed in the uphill face to minimize any disturbance caused by the backfilled soil. Furthermore, the sensors were installed with their widest dimension oriented vertically, to minimize the possibility of water collecting on its surface. The volumetric water-content sensor depths for each soil pit are shown in table 1. 


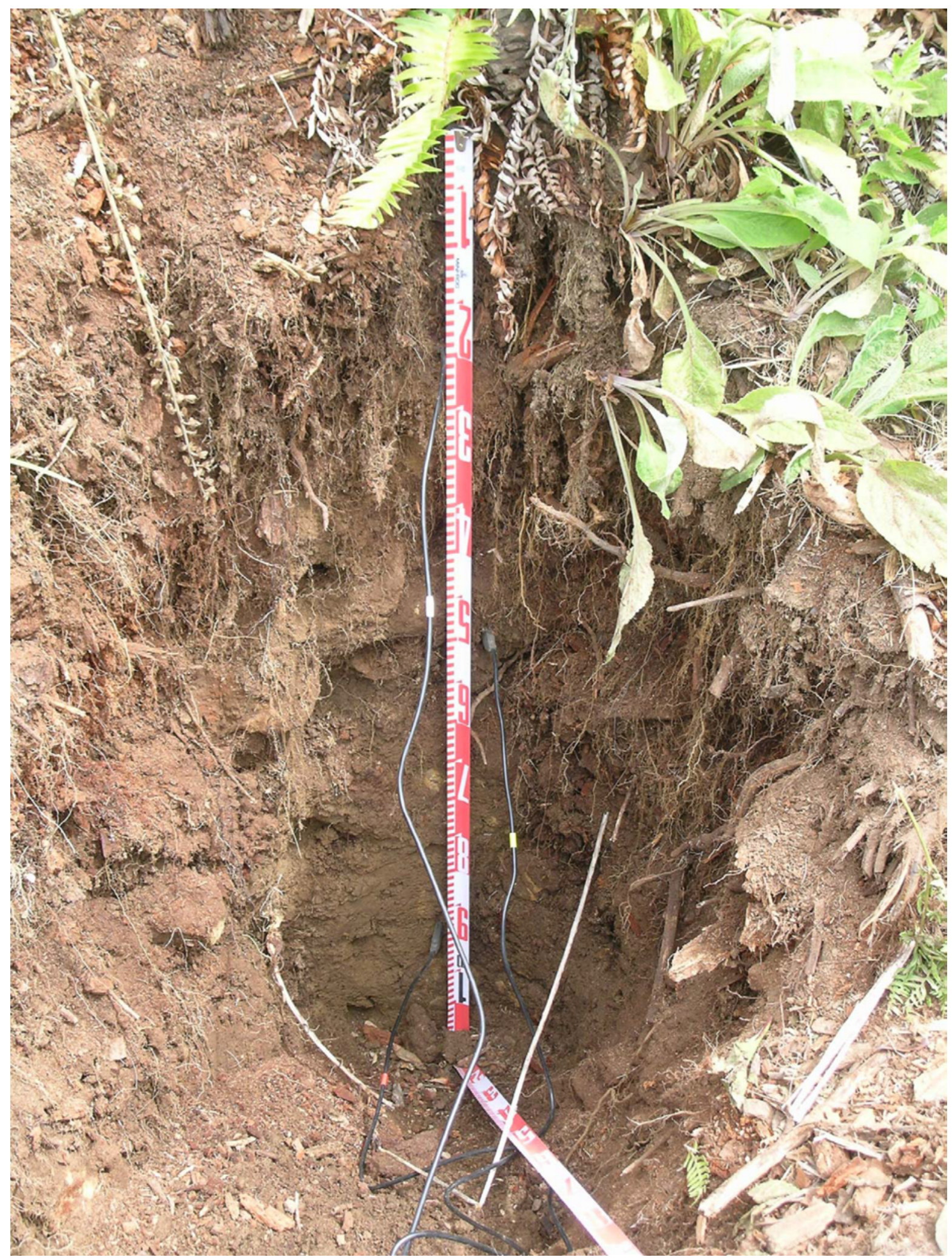

Figure 8. Typical volumetric water content-sensor installation. Scale is inverted to show depth beneath ground surface. 
Table 1. Locations and depths of volumetric water-content sensors. (cm, centimeters)

\begin{tabular}{|cccc|}
\hline Location & \multicolumn{3}{c|}{ Sensor Depth, cm } \\
\hline SP-1 & 20 & 50 & 93 \\
SP-2 & 20 & 50 & 125 \\
SP-3 & 20 & 50 & 94 \\
SP-4 & 20 & 50 & 75 \\
SP-5 & 20 & 50 & 160 \\
SP-6 & 20 & 50 & 90 \\
SP-7 & 20 & 50 & 80 \\
SP-8 & 20 & 50 & 80 \\
\hline
\end{tabular}

\section{Tensiometers}

Tensiometers allow a direct measurement of both positive and negative pore pressures in soil. The tensiometers installed at the site (Umwelt-Monitoring-Systeme [UMS] T8 external refilling field tensiometer) are designed for field applications. They are refillable, porous ceramic cup sensors with an integrated thermistor and a cable-mounted atmospheric pressure reference membrane. The tensiometers have a published measurement range of $-85 \mathrm{kPa}$ (soil suction) to $100 \mathrm{kPa}$ (positive pore pressure) and an accuracy of plus or minus $0.5 \mathrm{kPa}$. Because the porous ceramic cup of the tensiometer is in contact with the soil, long periods of dry soil conditions with pressures less than about $-85 \mathrm{kPa}$ cause the water in the instrument to cavitate and ultimately lose vacuum. At this point the readings no longer reflect the pore pressures in the soil, and the instrument's reading approaches atmospheric pressure over a period of weeks. At the Knife Ridge site, the tensiometers are refilled in late September or October in order to obtain accurate pressure measurements during the wet season when infiltrating rainfall elevates pore pressures above the cavitation pressure.

The tensiometers were placed in hand-augered boreholes approximately normal to the ground surface within about $1 \mathrm{~m}$ of the soil pits where the volumetric water-content sensors are located (figs. 6 and 9). This installation procedure places the porous ceramic cup vertically below undisturbed soil (fig. 10) and allows for complete refilling of the tensiometer without removal of the instrument. The vertical depth, $\mathrm{D}$, was determined by measuring the slope normal depth, $\mathrm{L}$, the local slope, $\delta$, and the instrument inclination, $\alpha$ (fig. 10, table 2). Protective housings, constructed of 2-in plastic pipe and fittings, cover the aboveground part of each tensiometer refill tube as shown in the upper left of figure 9 . The protective housings were initially black ABS pipe and fittings and were changed to white PVC in May 2012. The change to white PVC was made to decrease the diurnal, thermally driven (apparent) pressure changes discussed in the "Data Processing" section. 


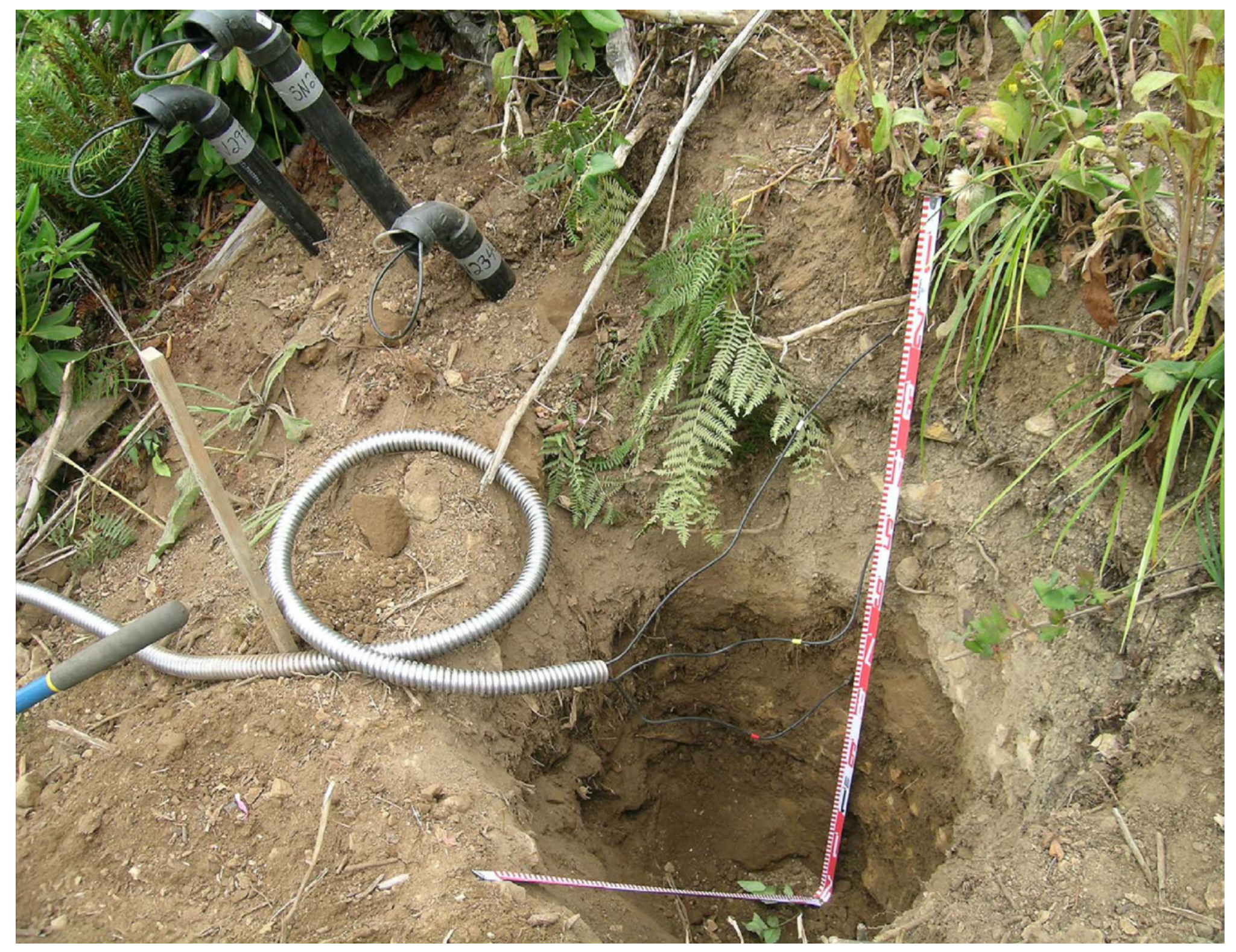

Figure 9. Photograph of typical sensor nest configuration and tensiometer housings. 


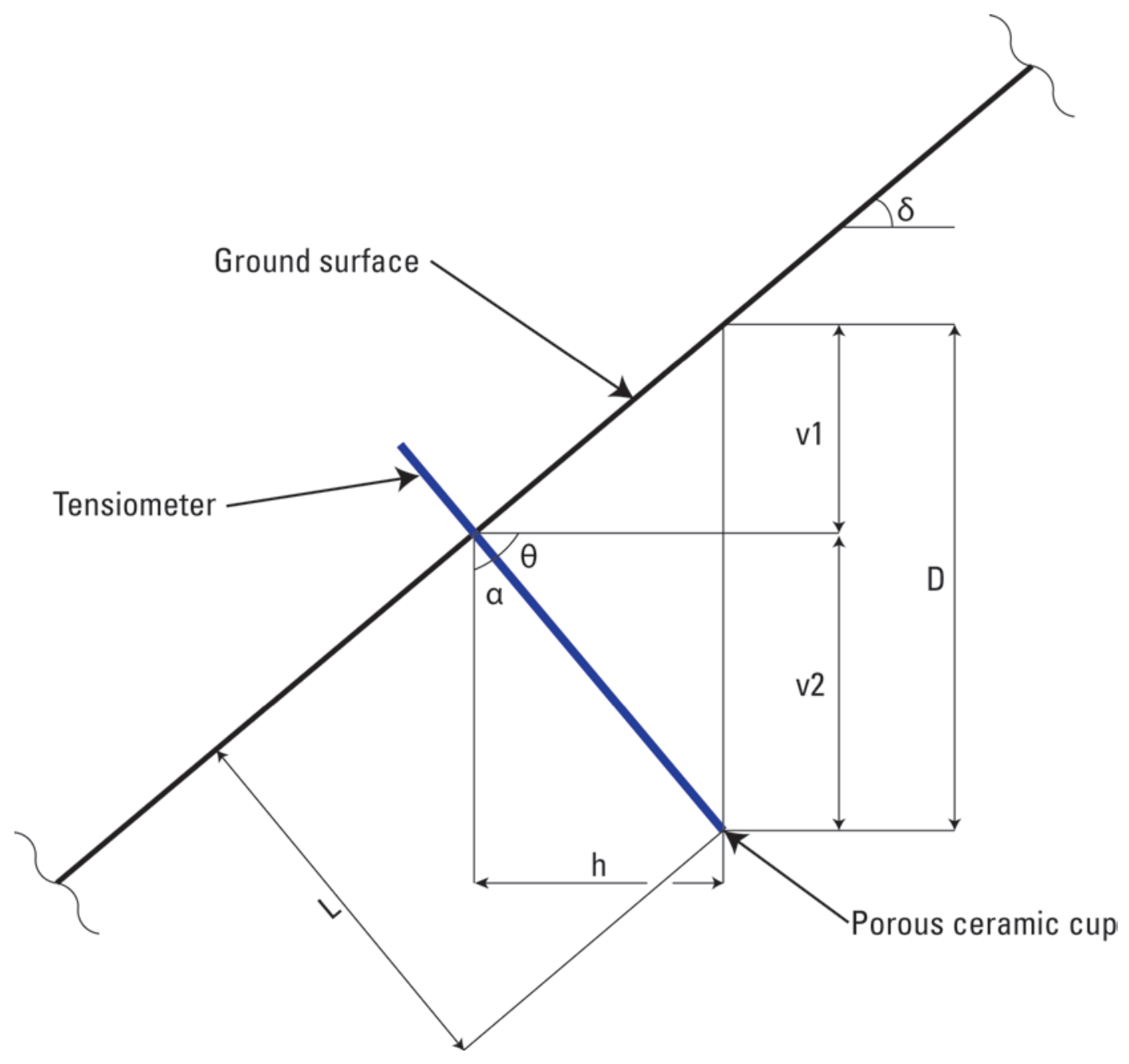

Figure 10. Tensiometer installation geometry (protective housing not shown). Depths, $D$, for each tensiometer are listed in table 2. $(\delta$, local slope; $L$, slope normal depth of tensiometer; $\theta$, instrument plunge; $a$, instrument inclination; v1, vertical distance above the intersection of the tensiometer and ground surface to the ground surface above the tensiometer tip; v2, vertical distance below the intersection of the tensiometer and ground surface to the tensiometer tip; $\mathrm{D}$, depth of the tensiometer tip beneath the ground surface) 
Table 2. Tensiometer installation information. See figure 10 for installation geometry. $(\delta$, local slope; $L$, slope normal depth of tensiometer; $\theta$, tensiometer plunge; $\alpha$, tensiometer inclination; $v 1$, vertical distance above the intersection of the tensiometer and ground surface to the ground surface above the tip; v2, vertical distance below the intersection of the tensiometer and ground surface to the tensiometer tip; D, depth of the tensiometer tip beneath the ground surface)

\begin{tabular}{|c|c|c|c|c|c|c|c|c|}
\hline $\begin{array}{l}\text { Site } \\
\text { name }\end{array}$ & $\begin{array}{c}\text { Local slope } \delta \\
\text { (degrees) }\end{array}$ & $\begin{array}{l}\text { Tensiometer } \\
\text { depth } \mathrm{L}(\mathrm{cm})\end{array}$ & $\begin{array}{c}\begin{array}{c}\text { Plunge } \theta \\
\text { (degrees) }\end{array}\end{array}$ & $\begin{array}{l}\text { Inclination } \alpha \\
\text { (degrees) }\end{array}$ & v1 (cm) & $\mathrm{h}(\mathrm{cm})$ & v2 $(\mathrm{cm})$ & $\begin{array}{c}\text { Depth D } \\
\text { (cm) }\end{array}$ \\
\hline \multirow[t]{3}{*}{ SP-1 } & 37 & 195 & 52 & 38 & 154 & 120 & 90 & 244 \\
\hline & & 90 & 50 & 40 & 69 & 58 & 44 & 113 \\
\hline & & 50 & 55 & 35 & 41 & 29 & 22 & 63 \\
\hline \multirow[t]{3}{*}{ SP-2 } & 45 & 200 & 46 & 44 & 144 & 139 & 139 & 283 \\
\hline & & 90 & 52 & 38 & 71 & 55 & 55 & 126 \\
\hline & & 50 & 51 & 39 & 39 & 31 & 31 & 70 \\
\hline \multirow[t]{3}{*}{ SP-3 } & 38 & 165 & 53 & 37 & 132 & 99 & 78 & 209 \\
\hline & & 105 & 57 & 33 & 88 & 57 & 45 & 133 \\
\hline & & 50 & 55 & 35 & 41 & 29 & 22 & 63 \\
\hline \multirow[t]{3}{*}{ SP-4 } & 35 & 180 & 57 & 33 & 151 & 98 & 69 & 220 \\
\hline & & 80 & 60 & 30 & 69 & 40 & 28 & 97 \\
\hline & & 50 & 62 & 28 & 44 & 23 & 16 & 61 \\
\hline \multirow[t]{3}{*}{ SP-5 } & 32 & 210 & 61 & 29 & 184 & 102 & 64 & 247 \\
\hline & & 110 & 65 & 25 & 100 & 46 & 29 & 129 \\
\hline & & 50 & 65 & 25 & 45 & 21 & 13 & 59 \\
\hline \multirow[t]{3}{*}{ SP-6 } & 35 & 200 & 57 & 33 & 168 & 109 & 76 & 244 \\
\hline & & 100 & 57 & 33 & 84 & 54 & 38 & 122 \\
\hline & & 50 & 60 & 30 & 43 & 25 & 18 & 61 \\
\hline \multirow[t]{3}{*}{ SP-7 } & 37 & 198 & 49 & 41 & 149 & 130 & 98 & 247 \\
\hline & & 95 & 53 & 37 & 76 & 57 & 43 & 119 \\
\hline & & 50 & 55 & 35 & 41 & 29 & 22 & 63 \\
\hline \multirow[t]{3}{*}{ SP-8 } & 39 & 100 & 52 & 38 & 79 & 62 & 50 & 129 \\
\hline & & 75 & 50 & 40 & 57 & 48 & 39 & 96 \\
\hline & & 50 & 55 & 35 & 41 & 29 & 23 & 64 \\
\hline
\end{tabular}

\section{Piezometers}

Three vibrating wire piezometers (Durham Geo Slope Indicator VW Piezometer, $345 \mathrm{kPa}$ range) were installed in open, cased monitoring wells along the axis of the basin (P1, P2, P3, fig. 2); one near each of the monitoring arrays SP-2, SP-1, and SP-5. An electric jackhammer driving a $63.5 \mathrm{~mm}$ directpush soil sampler was used to bore to bedrock. The borehole was cased using PVC with its lower $25 \mathrm{~cm}$ 
slotted and was backfilled with sand to $25 \mathrm{~cm}$. The outer diameter of the casing was backfilled with native material.

Each vibrating wire piezometer consists of a tensioned steel wire connected to a diaphragm that contracts due to direct hydraulic pressure; therefore, the "at rest" condition of this sensor is at atmospheric pressure (at sea level) where the manufacturer-provided calibration data cause the sensor to output zero (error is within 0.1 percent of full range, or plus or minus $0.35 \mathrm{kPa}$ ). That is, the sensor can only read pressures as low as barometric pressure at any given elevation and, unlike a tensiometer, is not equipped to read soil suction. Movement of the diaphragm causes a change in tension on the wire and, when excited by an electromagnetic coil, causes the wire's fundamental resonating frequency to change. This signal is transmitted to an interface (Campbell Scientific AVW1), which conditions and provides amplification to the signal as it is passed to the datalogger.

Several measures were required to insure reliable data from the piezometers. Initial sensor readings taken before installation were recorded in order to determine pressure offset due to elevation. The piezometer output is temperature dependent, and each instrument has an integrated thermistor (thermal resistor) to provide a temperature correction. An additional piezometer was mounted in a radiation shield (aboveground) in order to provide a barometric correction as the sensor's readings are influenced by atmospheric pressure fluctuation.

Table 3. Table showing location and depth of vibrating-wire piezometers. (cm, centimeters)

\begin{tabular}{|cc|}
\hline Location & Sensor Depth, cm \\
\hline SP-1 & 316 \\
SP-2 & 150 \\
SP-5 & 327 \\
\hline
\end{tabular}

\section{Inclinometers}

Three "in-place inclinometers" (Applied Geomechanics Model 906v-h "Little Dipper") are located in boreholes near the areas assumed to have the greatest slope-failure potential: near SP-1, SP-2, and SP-7 (fig. 2). The inclinometers use an electrolytic tilt transducer made up of a vial that contains five electrodes and a conductive liquid. Tilting causes the conductive liquid to cover and uncover opposing electrodes; thus, the resistance (voltage drop) can be measured along the paths of the internal circuitry. Since the four outer electrodes are located in four quadrants, the clinometer can detect rotational magnitude about two orthogonal axes. The inclinometers are installed approximately one meter below the ground surface in PVC pipe. The sensors provide a range of plus or minus 12 degrees and a resolution of 5 millidegrees, with a published repeatability of 10 millidegrees. The sensor's output is temperature dependent and uses an internal thermistor for temperature correction.

\section{Data Processing}

Preliminary data processing is carried out at USGS offices in Golden, Colo., where the data are archived, displayed on the Internet, and prepared for analysis. The automated processing steps include: file retrieval, scanning for communication errors, sorting, and reformatting of the data from the NRCS 
server. Additionally, data plots are updated every $15 \mathrm{~min}$ and are copied to the USGS website. It should be noted that the graphs found in this report are not those that originally appeared on the USGS website. The archived data was further processed to produce the graphs for this report.

A program was written in Matlab to process and graph the data. The program first scans the data record to identify any data lapses (missing records). Missing records of less than a 3-hr interval are linearly interpolated and those longer than $3 \mathrm{hr}$ are flagged so they can be identified for omission by later plotting functions. Data are converted to engineering units and temperature corrections are applied.

The data are resampled from 15-min data into hourly data. For the rain-gage data, the program sums the four quarter-hourly records. Since some of these records are associated with data lapses, it should be noted that the precipitation record may represent the lower bound of the actual rainfall quantity. All other sensors were translated to hourly data by taking one sample at the hour (for example, sensor reading at 12:00). If these data at the top of an hour were absent, the program looks for data at the subsequent time slots $(12: 15,12: 30,12: 45)$; if no data exist within the hour, the point is either linearly interpolated or flagged as invalid, depending on the overall size of the data gap. The data are then filtered using a band-pass filter to remove data values outside of a reasonable range of values for each type of sensor. The range limits are shown in table 4.

Table 4. Processing range limits for raw data. ( $\mathrm{mm} / \mathrm{hr}$, millimeters per hour; $\mathrm{kPa}$, kilopascals)

\begin{tabular}{|ccc|}
\hline Instrument & Lower Limit & Upper Limit \\
\hline Rain Gage & 0 & $200 \mathrm{~mm} \mathrm{hr}^{-1}$ \\
Tensiometer & $-85 \mathrm{kPa}$ & $50 \mathrm{kPa}$ \\
Water Content & $0 \%$ & $45 \%$ \\
Piezometer & $-10 \mathrm{kPa}$ & $10 \mathrm{kPa}$ \\
\hline
\end{tabular}

The tensiometer and piezometer data streams showed noticeable noise throughout the monitoring period. The tensiometer noise was determined to result from a thermally driven expansion of air within the sensor pressure column. When the tensiometers are completely filled with deaired water the apparent pressure variations due to thermal variation are small, however as air bubbles develop (through cavitation, evaporation, or exfiltration of water across the porous stone) the pressure fluctuations become large. White PVC housings installed at the site, mentioned in the Methods section, apparently reduced some of the temperature increases caused by solar radiation, however, temperature variation continued to cause a noticeable pressure swing in partially filled tensiometers (a pressure change of 5-20 kPa with more extreme fluctuations occurring in sensors under greater suction).

We determined that diurnal signal excursions or noise in the piezometer data was caused by a solar charge controller. Specifically, the Phase Width Modulation (PWM) charging feature of the solar charge controller was determined to be the cause of the noise. As the charge of the battery reached approximately 14 volts, this feature caused the charge delivered to the battery to pulse at $300 \mathrm{~Hz}$ to avoid overvoltage while still providing charging current. This feature was designed to increase battery life but caused electrical and/or mechanical noise. Due to the close proximity of the solar charge controller and the vibrating wire interface, this noise was transferred to the piezometer data stream. In 
October 2011, the PWM feature of the charge controller was turned off by disconnecting a pull-down resistor on the controller's circuit board, after which the data-stream noise was no longer present.

Final processing steps applied an averaging filter to remove noise from the tensiometer and piezometer data stream. This final filtering step consisted of a zero-phase filter (Oppenheim and Schafer, 1989; Gustafsson, 1996) that was used in order to ensure that the event timing of the signal was not transposed. It should be noted that this filter attenuates the signal an amount dependent on the sizing of the averaging parameter, which was 6 hours for both the tensiometer and piezometer data sets. This attenuation can be described as a smoothing of the waveform transients.

\section{System Reliability}

As a whole, the monitoring instruments and data acquisition and transmission have been reliable during the three Hydrologic Years (HY2010, HY2011, and HY2012), however, several sensors malfunctioned at various times. Data taken from sensors identified as malfunctioning have generally been left in unaltered form and included in the data plots (figs. 11-37) unless they are out of plot range. A brief description of affected instruments for each Hydrologic Year (HY) follows.

During HY2010, all three volumetric water-content sensors in SP2 (fig. 12), the volumetric water-content sensor at $75 \mathrm{~cm}$ in SP4 (fig. 14), as well as two tensiometers, at $119 \mathrm{~cm}$ at SP7 (fig. 17), and $209 \mathrm{~cm}$ (fig. 13) at SP3, provided noisy signals. Conversely, the tensiometer at $61 \mathrm{~cm}$ at SP4 (fig. 14) showed a flat signal that varied only slightly from a zero reading regardless of hydrologic activity observed at nearby instruments. As mentioned in the "Data Processing" section, much of the piezometer data was plagued by noise issues. Due to these noise issues, the piezometer data will not be discussed with the general hydrologic data; rather, it will be discussed separately in a subsequent section.

System reliability during HY2011 was very high, in that there were no instrumentation errors aside from those that arose during HY2010. The readings from the volumetric water-content instrument at $20 \mathrm{~cm}$ in SP2 (fig. 20) remained erratic throughout the entire hydrologic year. The sensors at $50 \mathrm{~cm}$ and $125 \mathrm{~cm}$ in the same soil pit were restored to a fully functional status when changes to the datalogger programming were made in October 2010. Tensiometers located at SP7 (119 cm, fig. 25) and SP3 (209 $\mathrm{cm}$, fig. 21) continued to exhibit transient noise while the tensiometer at SP4 at the depth of $61 \mathrm{~cm}$ reads near zero with little deviation throughout the year (fig. 22).

As in HY2011, system reliability during HY2012 was very high. The only problem was a data transfer outage that caused data loss for approximately the first two weeks of October. Fortunately, no further instrument outages beyond those present in HY2010 and HY2011 occurred. The faulty tensiometer located at the depth of $119 \mathrm{~cm}$ at SP7 was replaced in May 2012 (fig. 33).

\section{Summary of Data and Results}

The system installed in the Elliott State Forest provides a means to observe both long and shortterm changes in volumetric water content and pore pressures due to precipitation and infiltration. Figures 11-37 summarize the hydrological data collected at the site from November 2009 to September 2012. Figures 11-18, 19-26, and 27-34 show the pore-water response in each of the volumetric water content and tensiometer arrays (SP1-SP8) for Hydrologic Years 2010, 2011, and 2012, respectively. Figures 35-37 show the readings from the three piezometers. Distinct wet and dry periods do not coincide with the calendar year in the OCR - the wet season typically runs from October through May. Therefore, we plotted our data using the Hydrological Year, which runs from October 1 through September 30. Within a Hydrologic Year, data collected at individual soil pits are shown together along with hourly and cumulative rainfall in millimeters. 


\section{Hydrologic Year 2010}

For illustrative purposes, this section will discuss the data from SP1 (fig. 11). Figure 11 $A$ shows that the total rainfall over HY2010 was about $1,900 \mathrm{~mm}$. The hourly record shows that rainfall was frequent from October to June, but periods of no rainfall generally increased in duration after about the middle of April. Hourly rainfall in excess of $6 \mathrm{~mm}$ was more common in the early part of HY2010 than in the latter part of the year. The water content instruments in SP1 were not operational until about the first of November (fig. 11B). Initially, volumetric water contents at the three depths $(20,50$, and $93 \mathrm{~cm})$ were about 24, 28, and 27 percent, respectively. Water contents increased by a few percent with rainfall during the first few weeks after the instruments became operational, and in early December water contents increased at all three depths to between 31 and 39 percent. Volumetric water contents remained above 32 percent for the remainder of the wet period, which ended about the first of June. After that time, volumetric water contents steadily decreased. Pore-pressure measurements from the tensiometers show a similar pattern (fig. $11 C$ ), but the tensiometers were not operational until the middle part of December. Once the instruments equilibrated with the ambient soil conditions, the tensiometers, located 63,113 , and $244 \mathrm{~cm}$ vertically below the ground surface (table 2), indicated that pore pressures were negative, ranged between about -1 and $-4 \mathrm{kPa}$, and increased with depth. Pore pressures increased during or immediately following periods of rainfall and decreased in periods with no rain. No positive pore pressures were observed from this soil pit's tensiometers during HY2010. Similar to the measurements of volumetric water content (fig. 11B), pore pressures (fig. 11C) decreased with the cessation of rainfall in early June.

In HY2010, the water content instruments and tensiometers in the other soil pits responded similarly to those in SP1. Positive pore pressures were recorded at SP7 at $63 \mathrm{~cm}$ (fig. 17) and SP6 at 244 $\mathrm{cm}$ (fig. 16) following virtually any significant rainfall event.

Soil temperature data (not shown) taken from the tensiometers' built-in thermistors show an annual temperature centered around $8{ }^{\circ} \mathrm{C}$ with minima and maxima occurring in early March and late August, respectively. The only departure from this annual trend is associated with rainfall events where the soil temperature sometimes increased slightly (less than $0.5^{\circ} \mathrm{C}$ ) but returned to its pre-event temperature after moisture content levels approach pre-event conditions. Soil temperature tends to be buffered by soil depth so that a typical sensor's yearly differential can vary by as little as $1{ }^{\circ} \mathrm{C}$, for deep installations, or as much as $3{ }^{\circ} \mathrm{C}$ for shallow installations. 

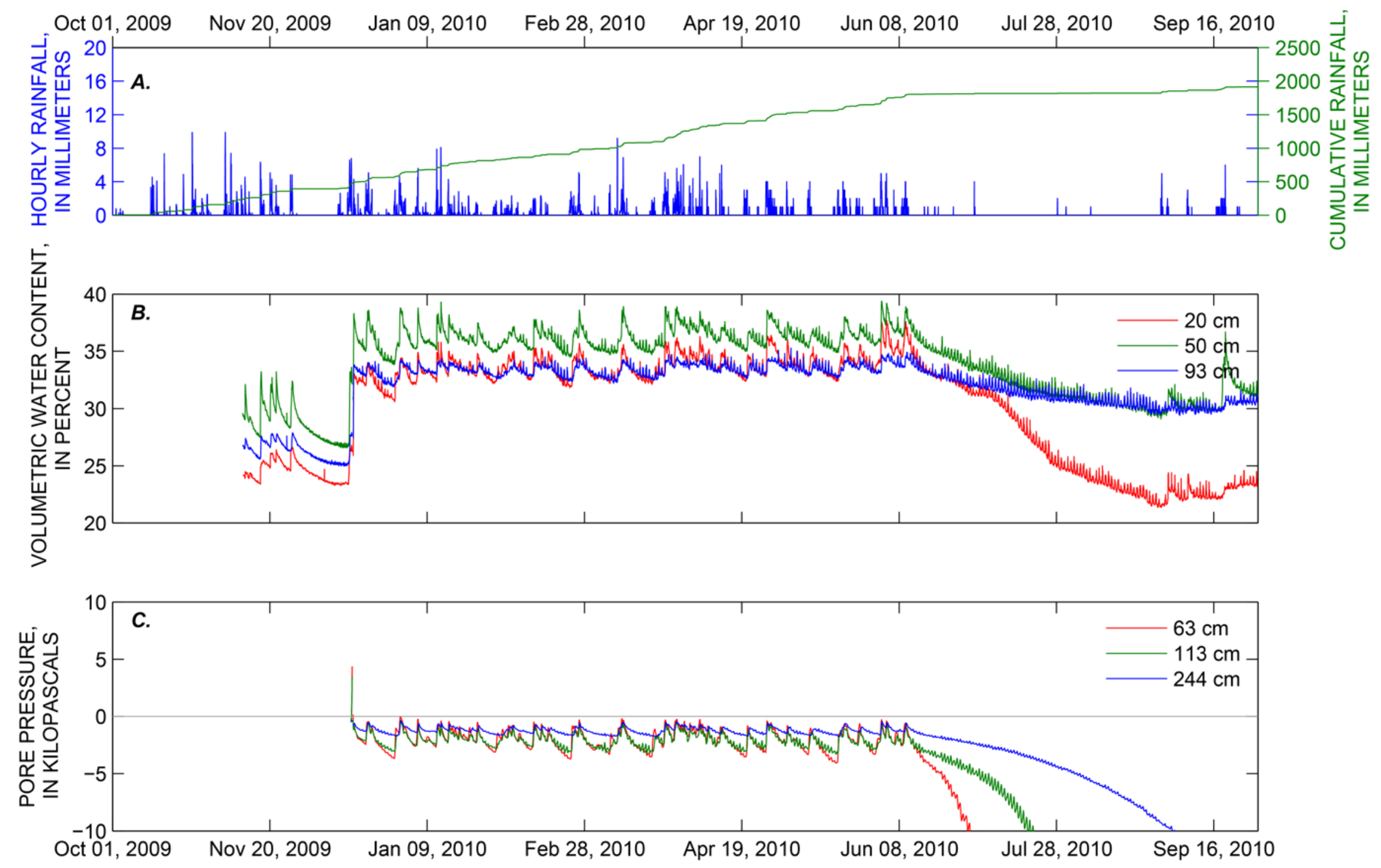

Figure 11. Hourly rainfall $A$, volumetric water content $B$, and pore pressure $C$ at Soil Pit 1 for HY2010. (HY, Hydrologic Year; cm, centimeters) 

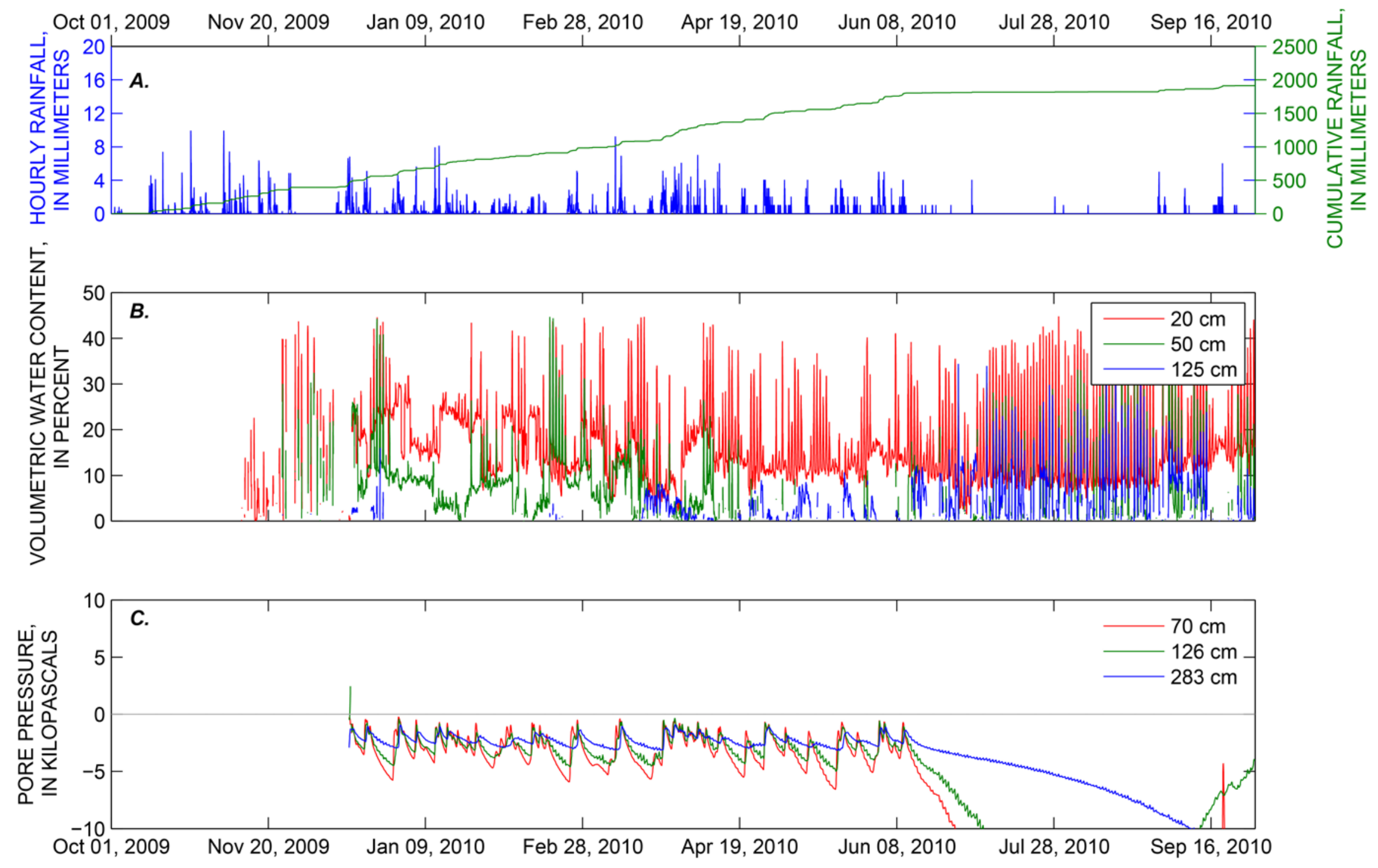

Figure 12. Hourly rainfall $A$, volumetric water content $B$, and pore pressure $C$ at Soil Pit 2 for HY2010. (HY, Hydrologic Year; cm, centimeters) 

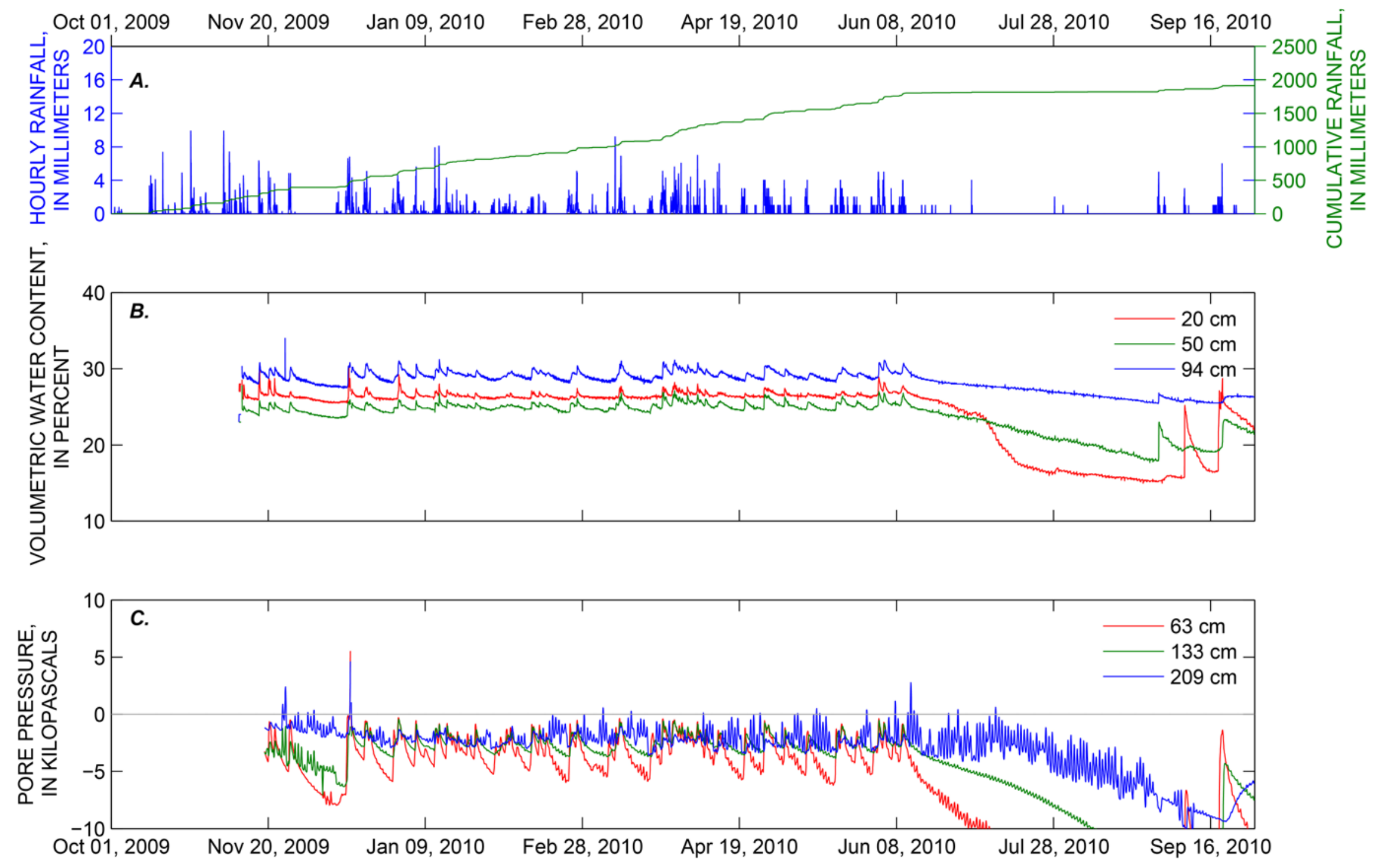

Figure 13. Hourly rainfall $A$, volumetric water content $B$, and pore pressure $C$ at Soil Pit 3 for HY2010. (HY, Hydrologic Year; cm, centimeters) 

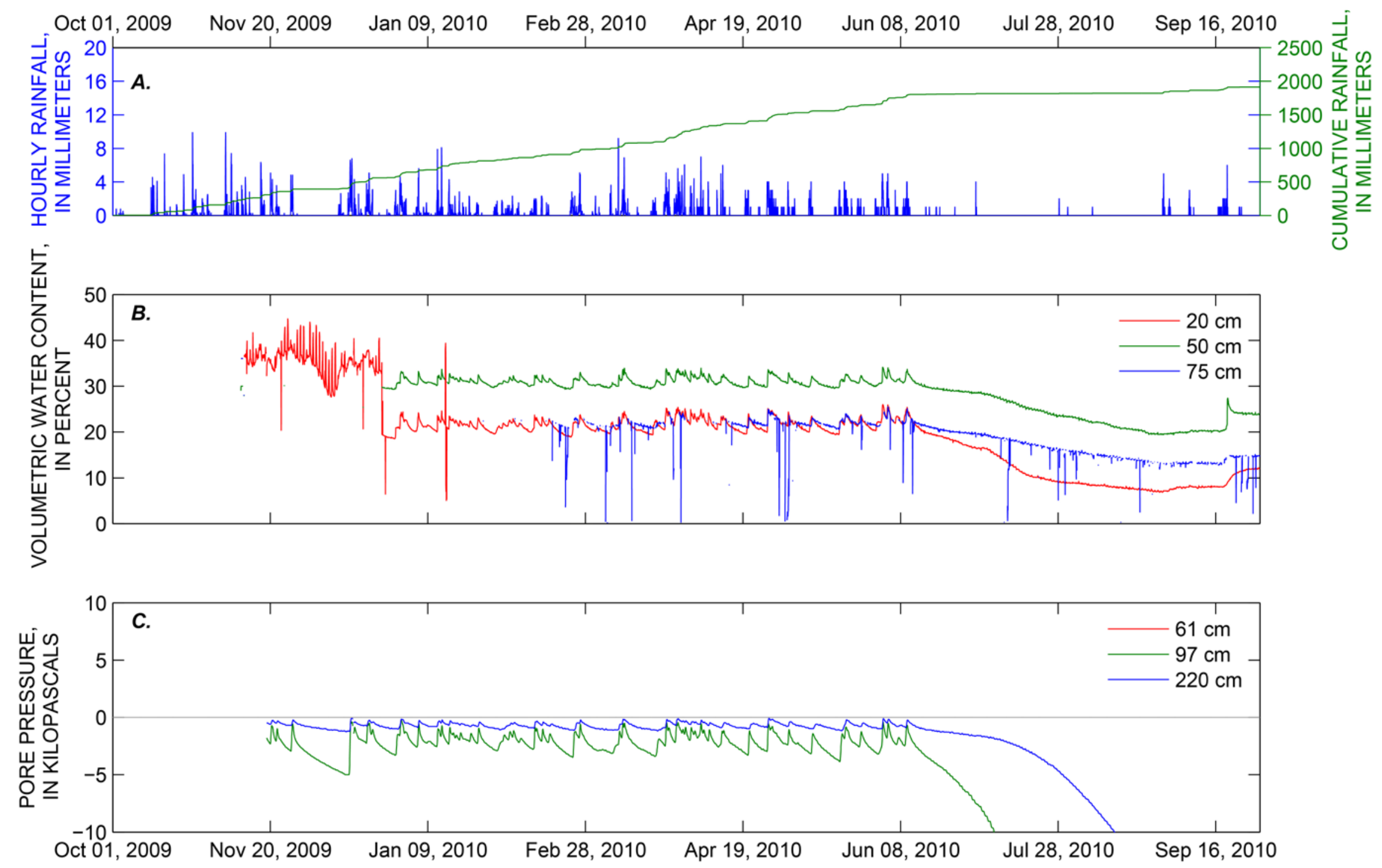

Figure 14. Hourly rainfall $A$, volumetric water content $B$, and pore pressure $C$ at Soil Pit 4 for HY2010. (HY, Hydrologic Year; $\mathrm{cm}$, centimeters) 

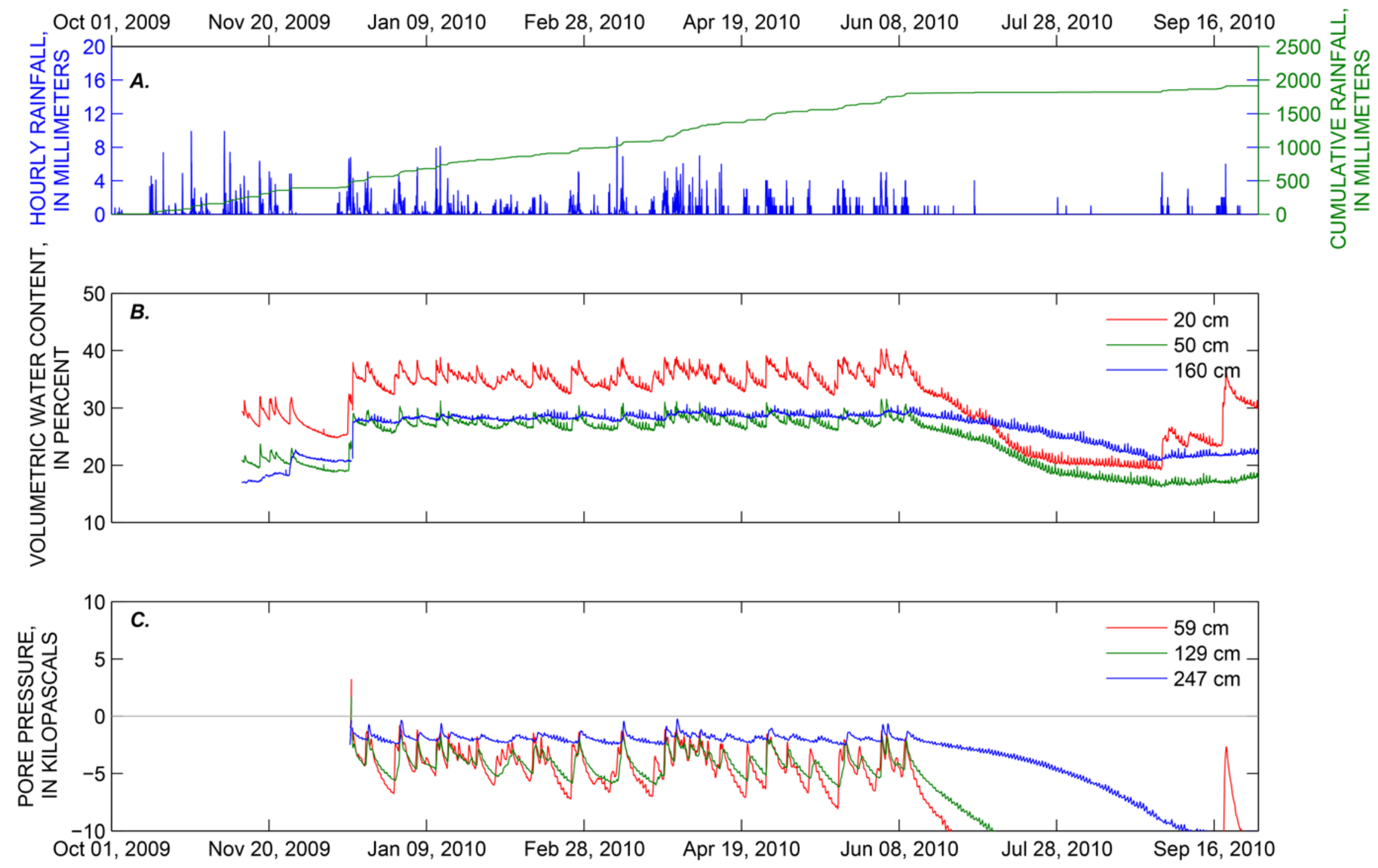

Figure 15. Hourly rainfall $A$, volumetric water content $B$, and pore pressure $C$ at Soil Pit 5 for HY2010. (HY, Hydrologic Year; cm, centimeters) 

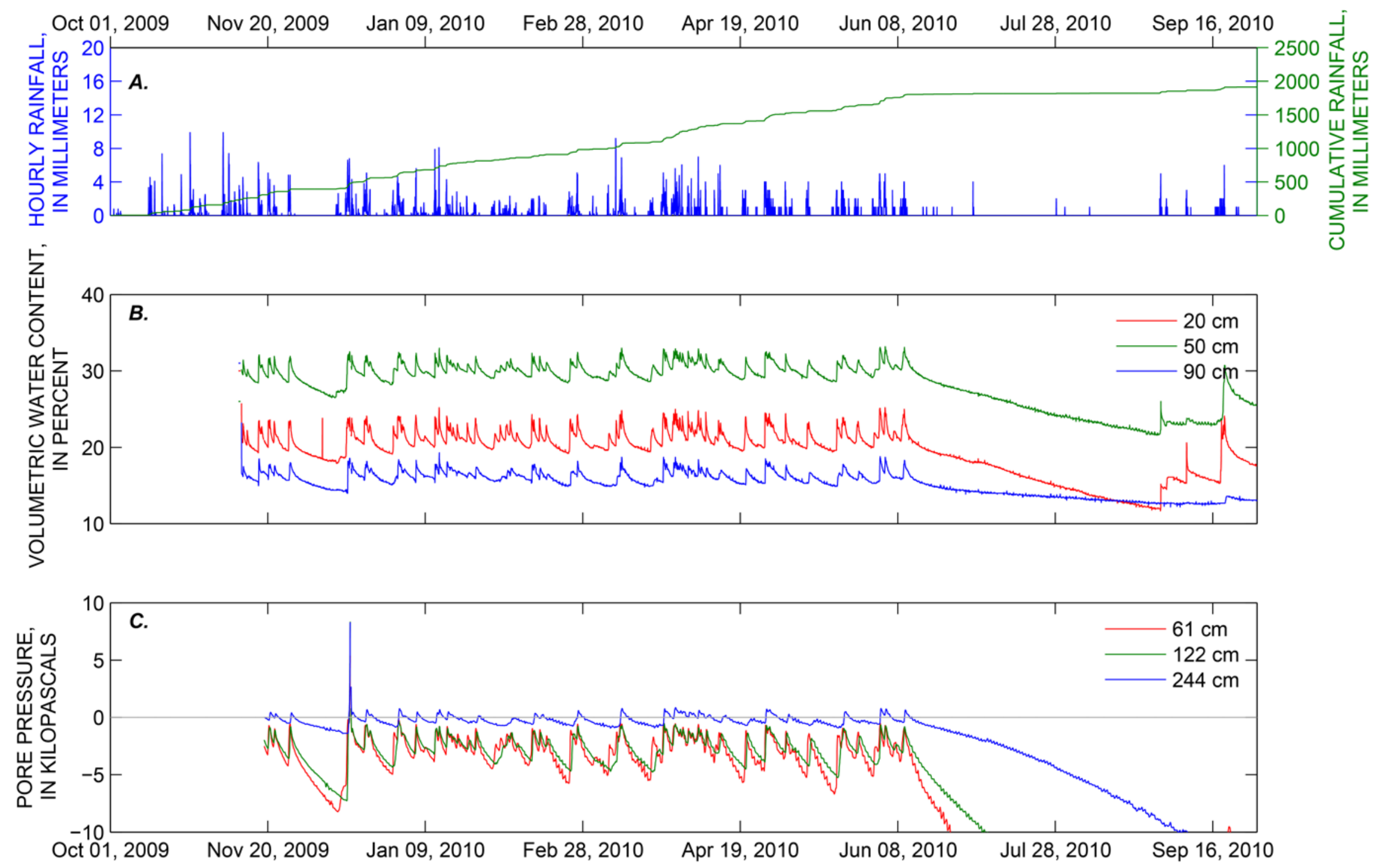

Figure 16. Hourly rainfall $A$, volumetric water content $B$, and pore pressure $C$ at Soil Pit 6 for HY2010. (HY, Hydrologic Year; $\mathrm{cm}$, centimeters) 

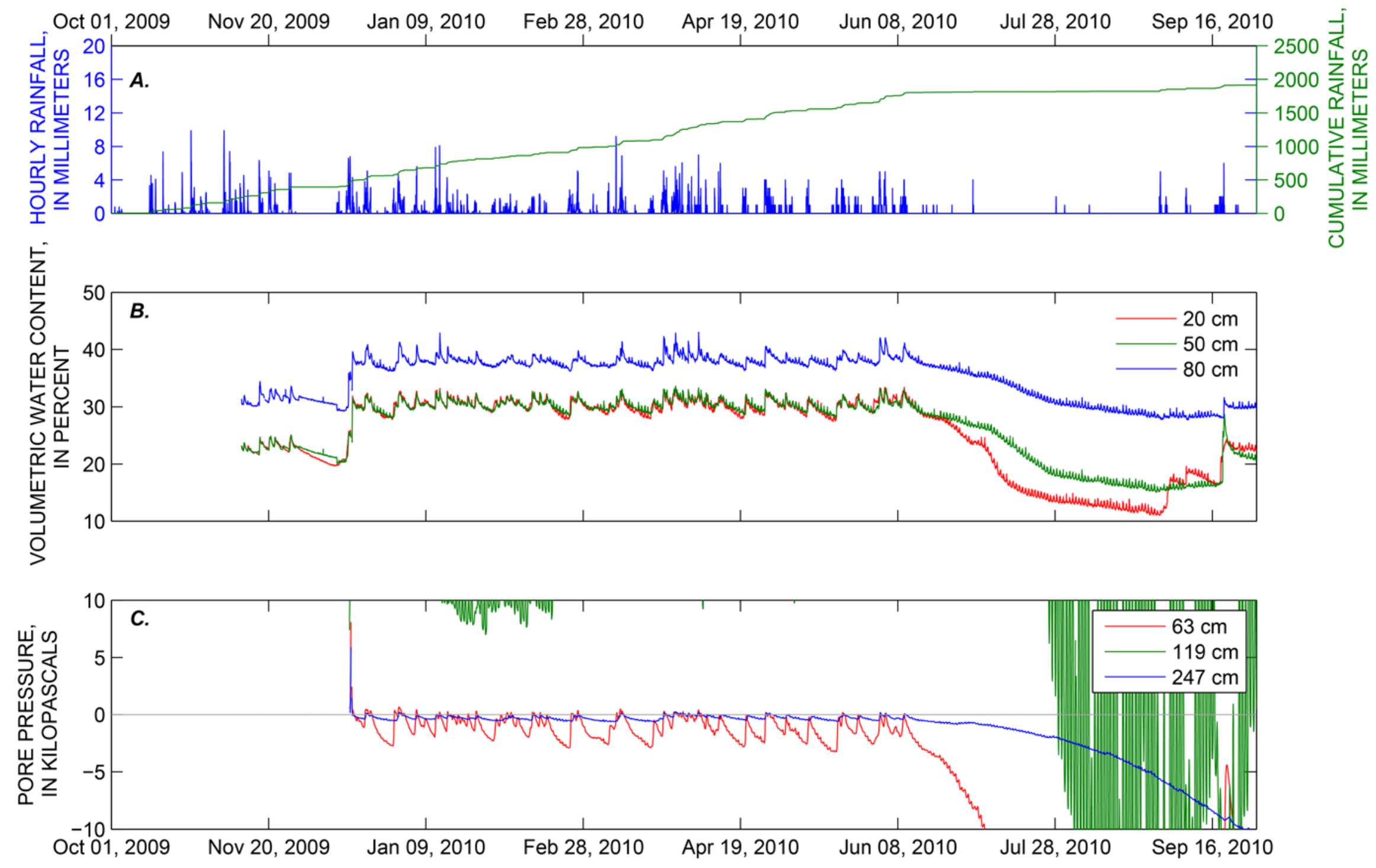

Figure 17. Hourly rainfall $A$, volumetric water content $B$, and pore pressure $C$ at Soil Pit 7 for HY2010. (HY, Hydrologic Year; cm, centimeters) 

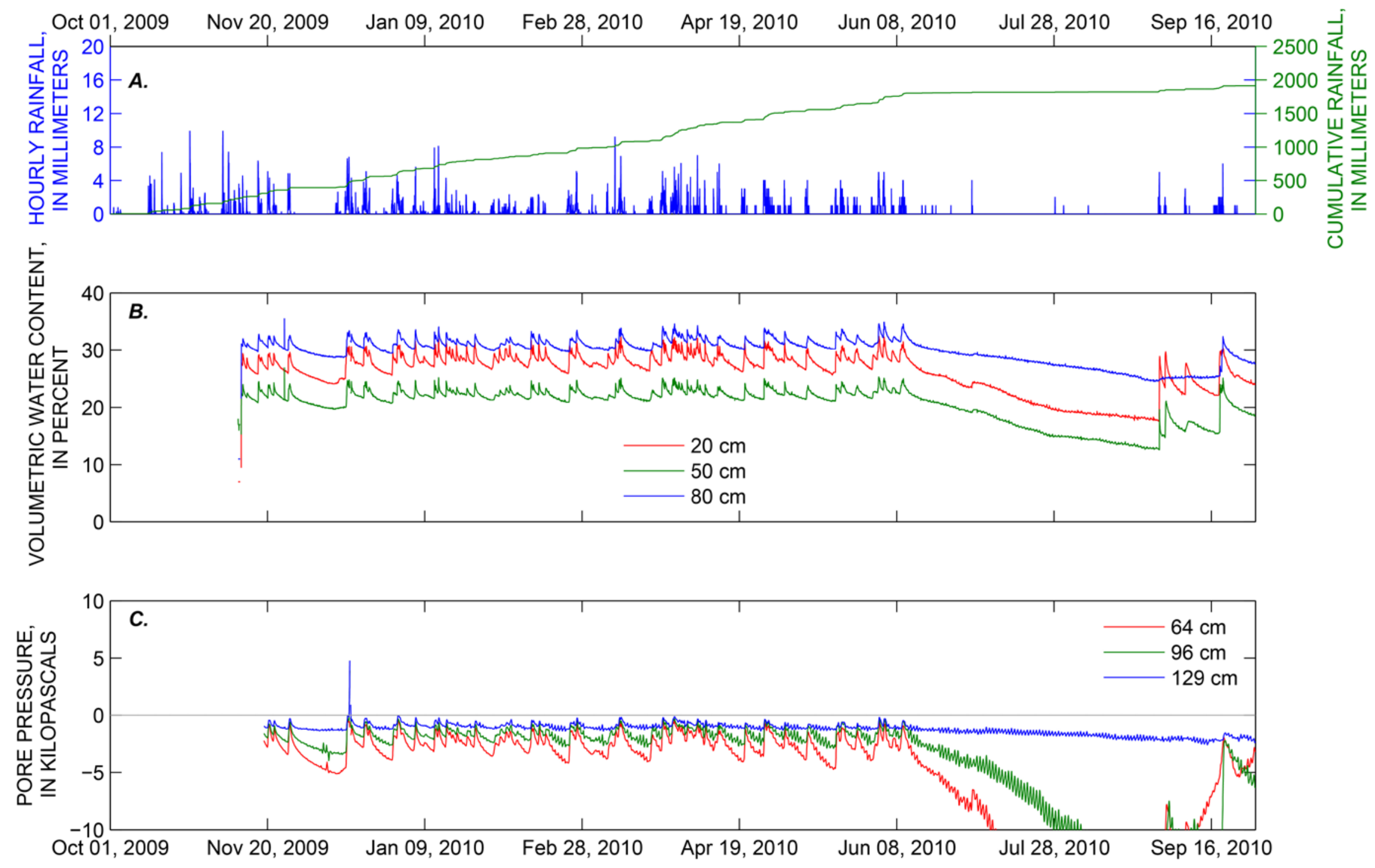

Figure 18. Hourly rainfall $A$, volumetric water content $B$, and pore pressure $C$ at Soil Pit 8 for HY2010. (HY, Hydrologic Year; cm, centimeters 


\section{Hydrologic Year 2011}

As in the previous year, the wet season of HY2011 was marked by an increase in pore pressures during the last weeks of October and by a gradual decline in pore pressure and volumetric water content beginning in June, as shown in figures 19-26. The tensiometer readings for the majority of the year varied between -4 and $-1 \mathrm{kPa}$. However, a rainfall event that occurred between January 13 and January 19 delivered approximately $165 \mathrm{~mm}$ of rain and pushed the pore pressure of SP1's tensiometer at $63 \mathrm{~cm}$ near zero (fig. 19). At this time the pore-pressure reading of SP5's tensiometer at $247 \mathrm{~cm}$ reached and sustained approximately $0.5 \mathrm{kPa}$ for around $8 \mathrm{hr}$ (fig. 23). Positive pore-pressure levels corresponding to this event can also be seen at SP7 (63 cm and $247 \mathrm{~cm}$, fig. 25), SP6 (244 cm, fig. 24), and SP4 (220 cm, fig. 22). Note that SP7's tensiometer at $63 \mathrm{~cm}$ (fig. 25) and SP6's tensiometer at $244 \mathrm{~cm}$ (fig. 24) generally trend towards positive pressures. 

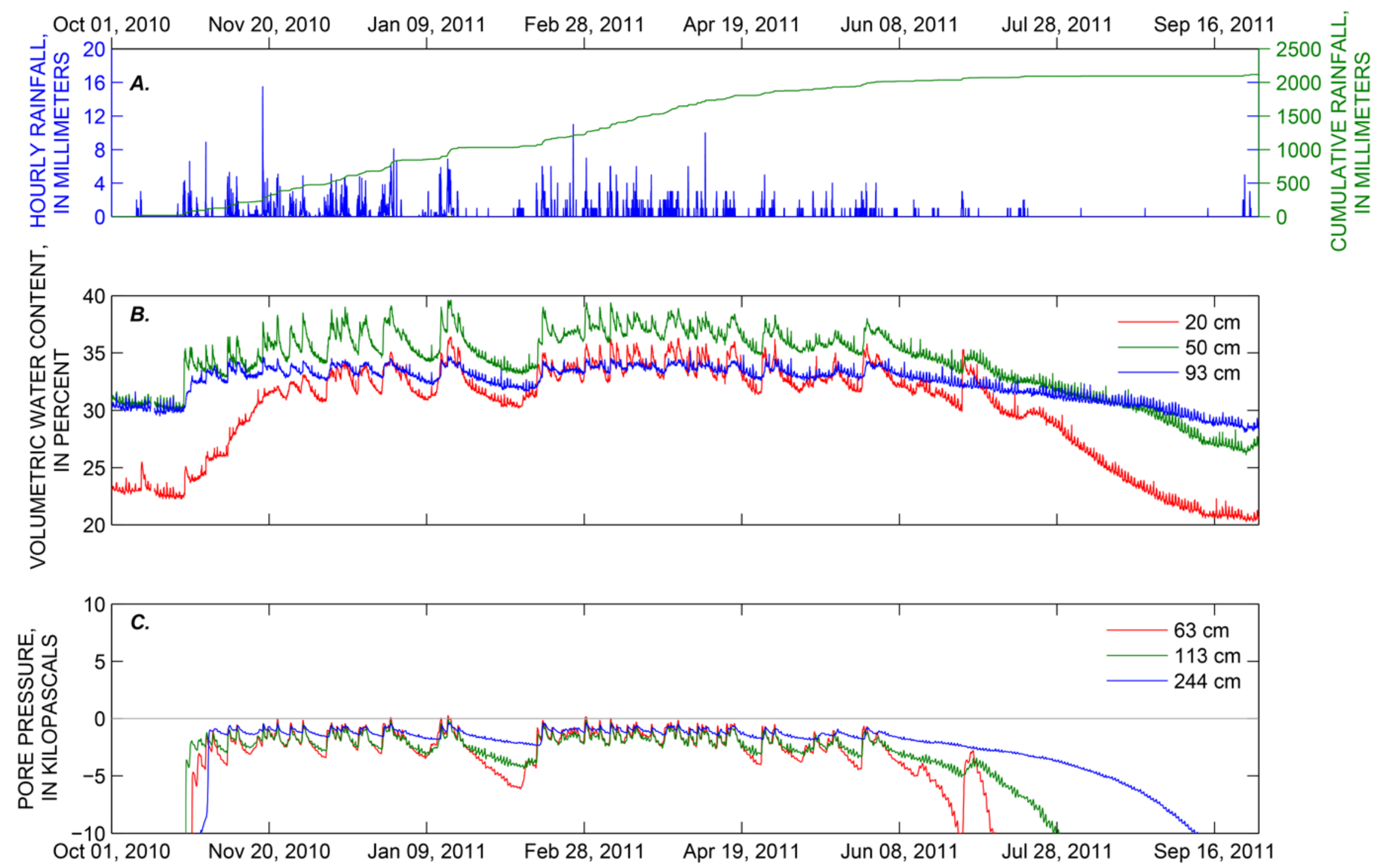

Figure 19. Hourly rainfall $A$, volumetric water content $B$, and pore pressure $C$ at Soil Pit 1 for HY2011. (HY, Hydrologic Year; cm, centimeters) 

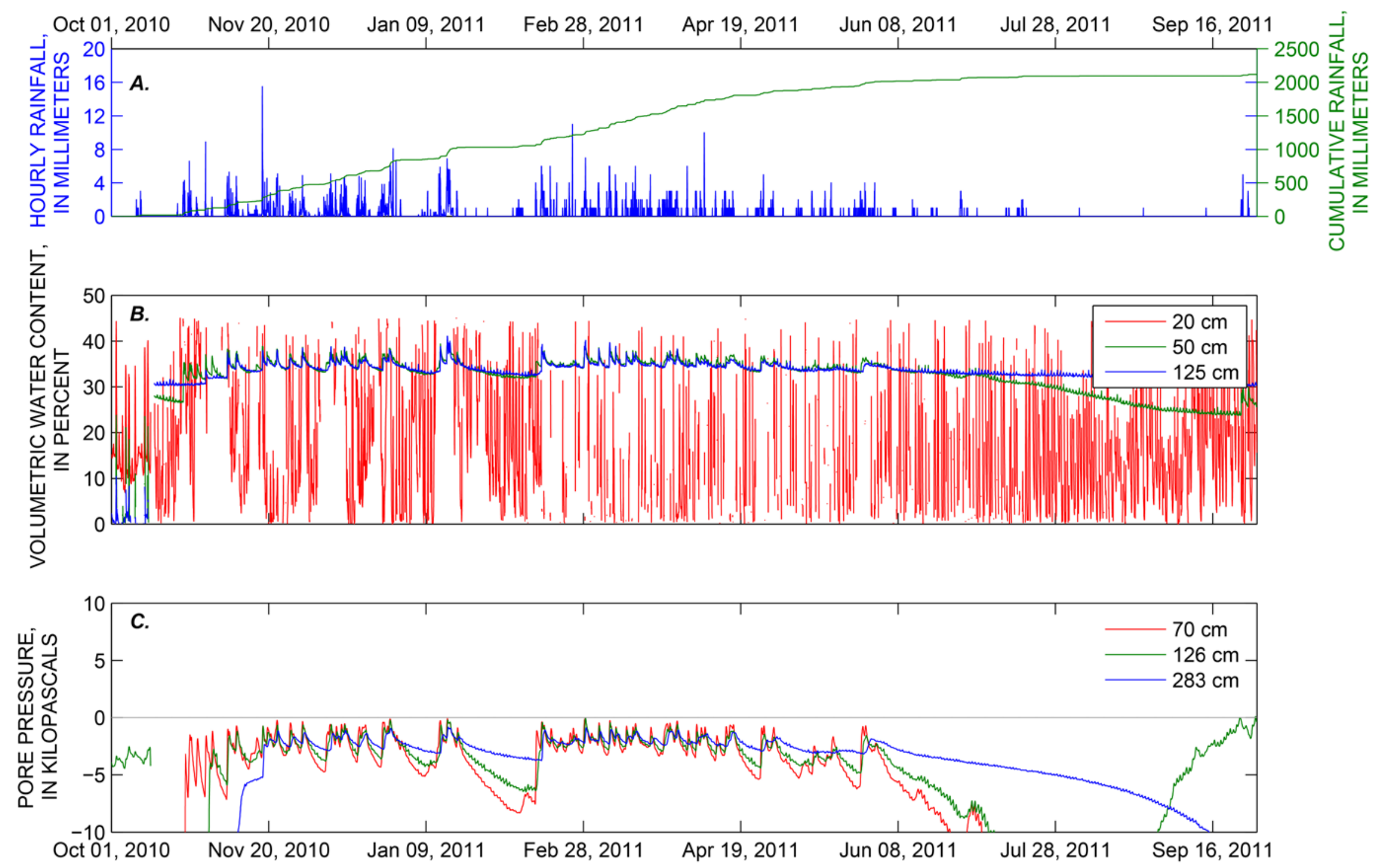

Figure 20. Hourly rainfall $A$, volumetric water content $B$, and pore pressure $C$ at Soil Pit 2 for HY2011. (HY, Hydrologic Year; cm, centimeters) 

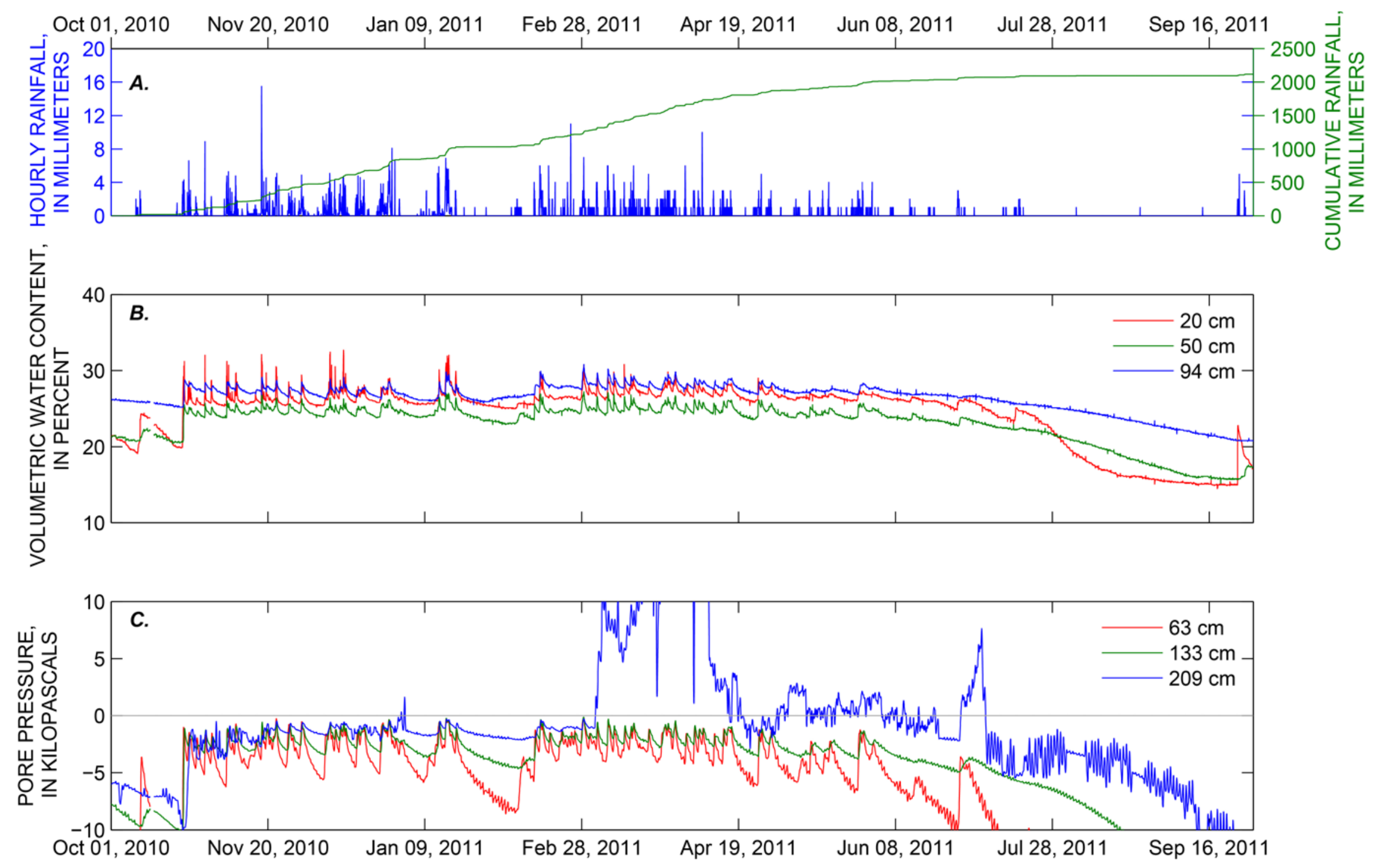

Figure 21. Hourly rainfall $A$, volumetric water content $B$, and pore pressure $C$ at Soil Pit 3 for HY2011. (HY, Hydrologic Year; cm, centimeters) 

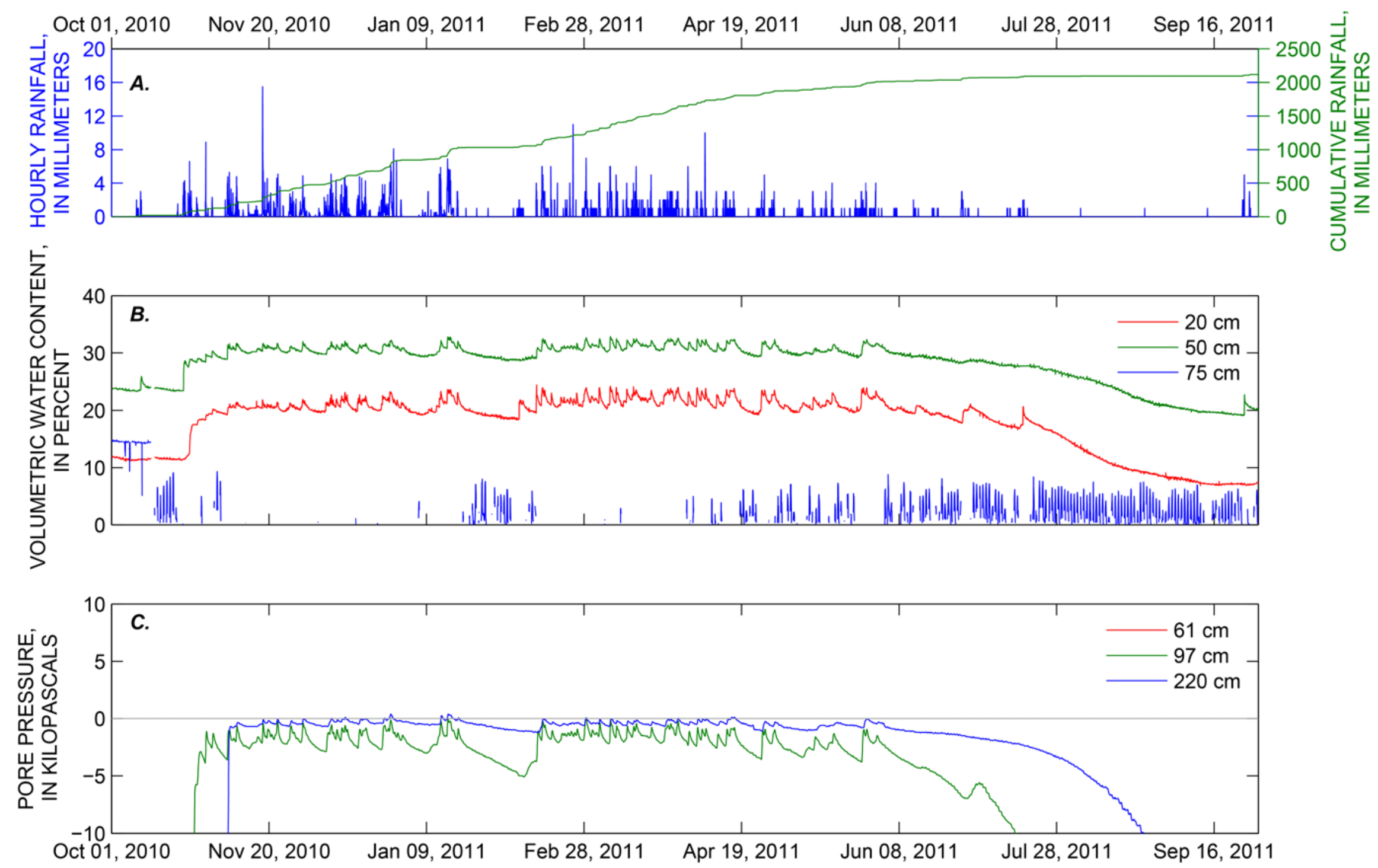

Figure 22. Hourly rainfall $A$, volumetric water content $B$, and pore pressure $C$ at Soil Pit 4 for HY2011. (HY, Hydrologic Year; cm, centimeters) 

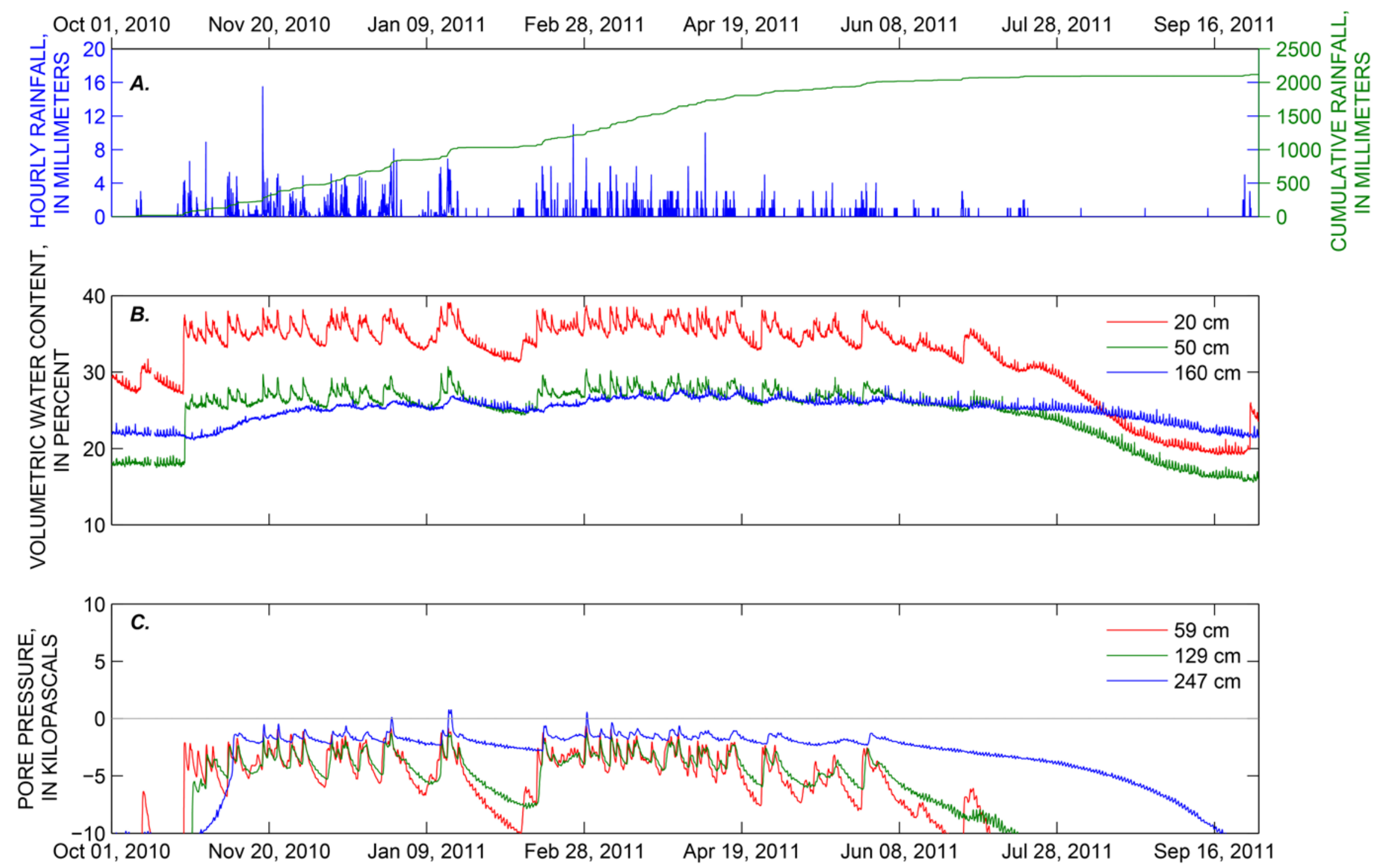

Figure 23. Hourly rainfall $A$, volumetric water content $B$, and pore pressure $C$ at Soil Pit 5 for HY2011. (HY, Hydrologic Year; cm, centimeters) 

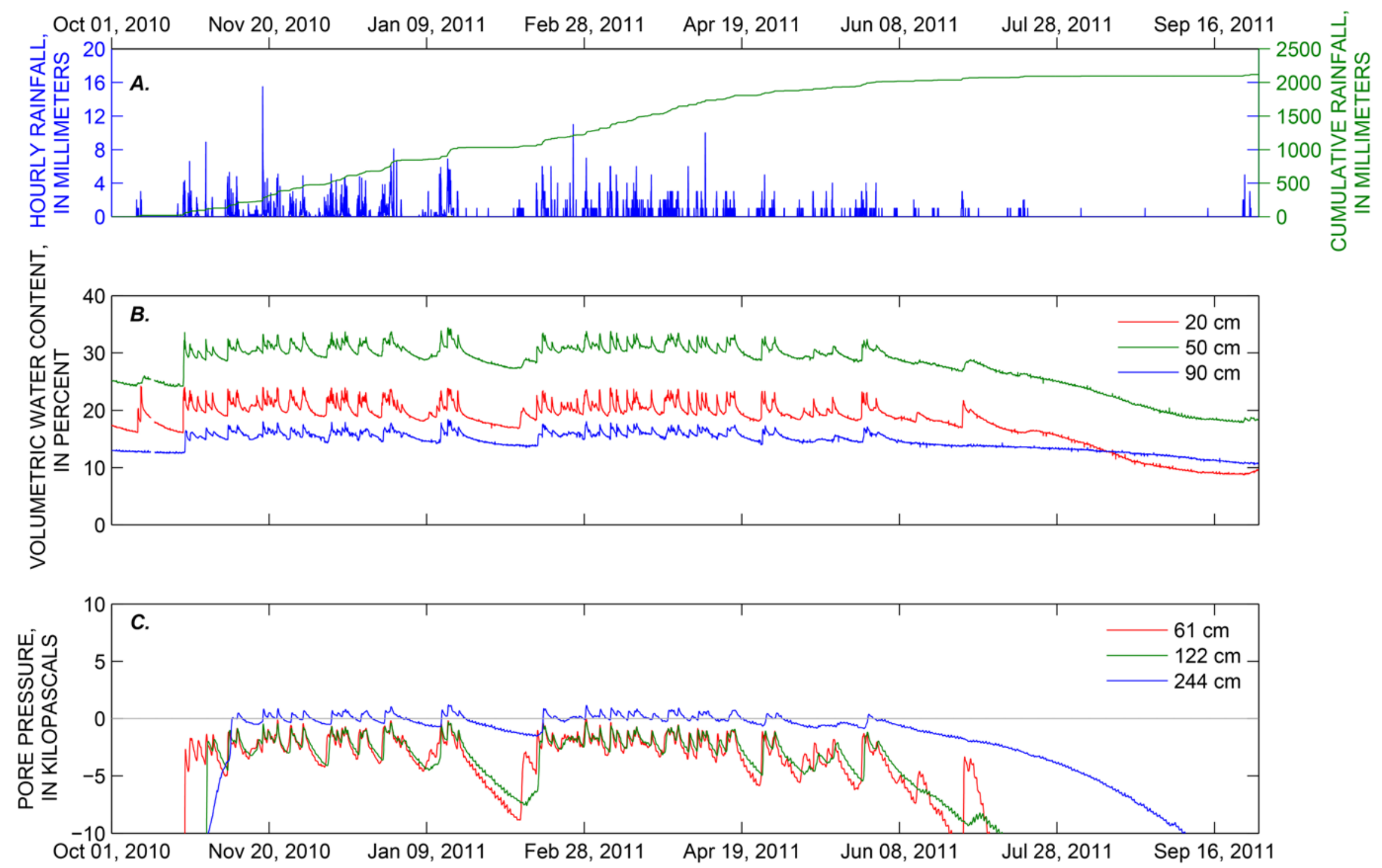

Figure 24. Hourly rainfall $A$, volumetric water content $B$, and pore pressure $C$ at Soil Pit 6 for HY2011. (HY, Hydrologic Year; cm, centimeters) 

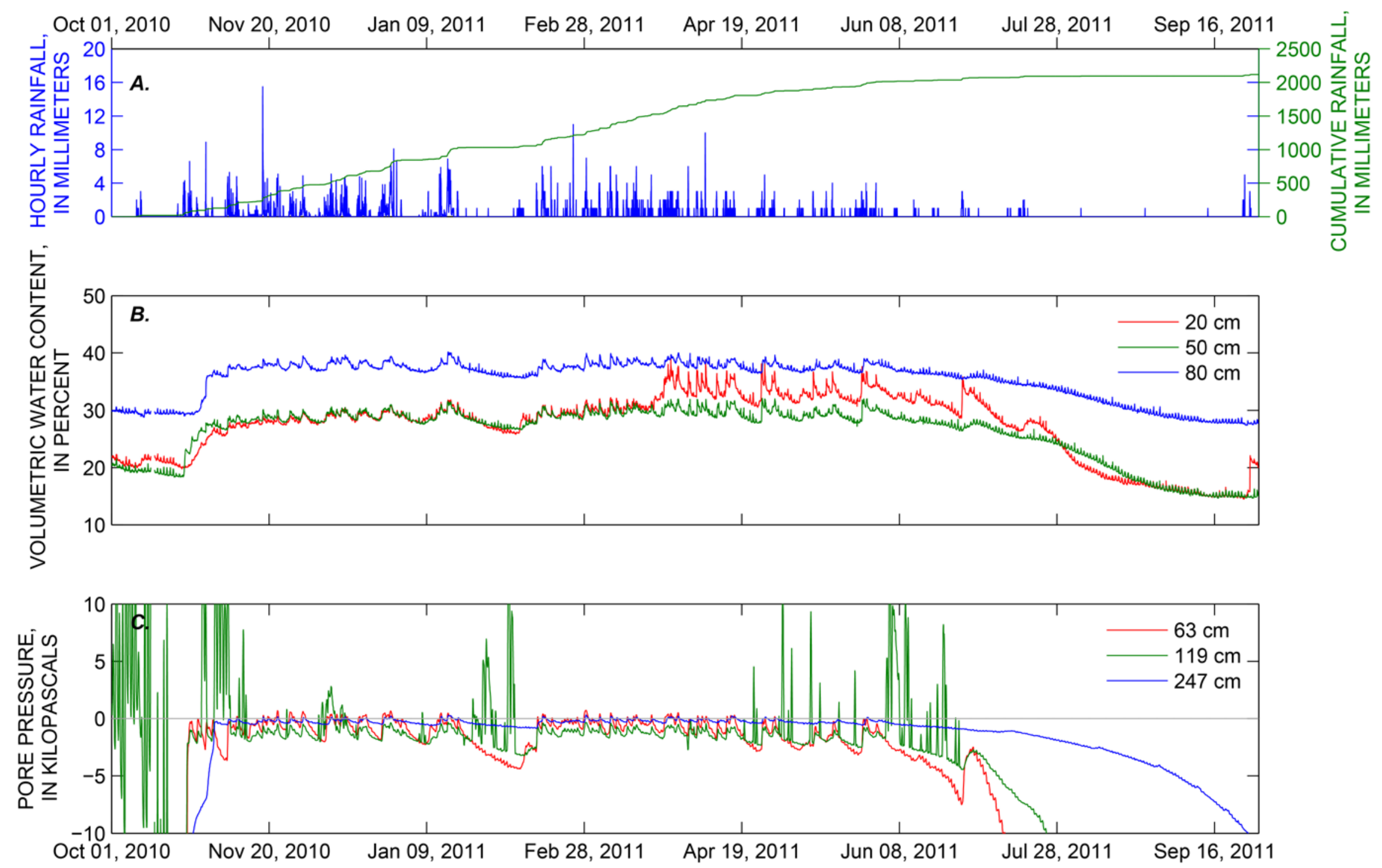

Figure 25. Hourly rainfall $A$, volumetric water content $B$, and pore pressure $C$ at Soil Pit 7 for HY2011. (HY, Hydrologic Year; $c m$, centimeters) 

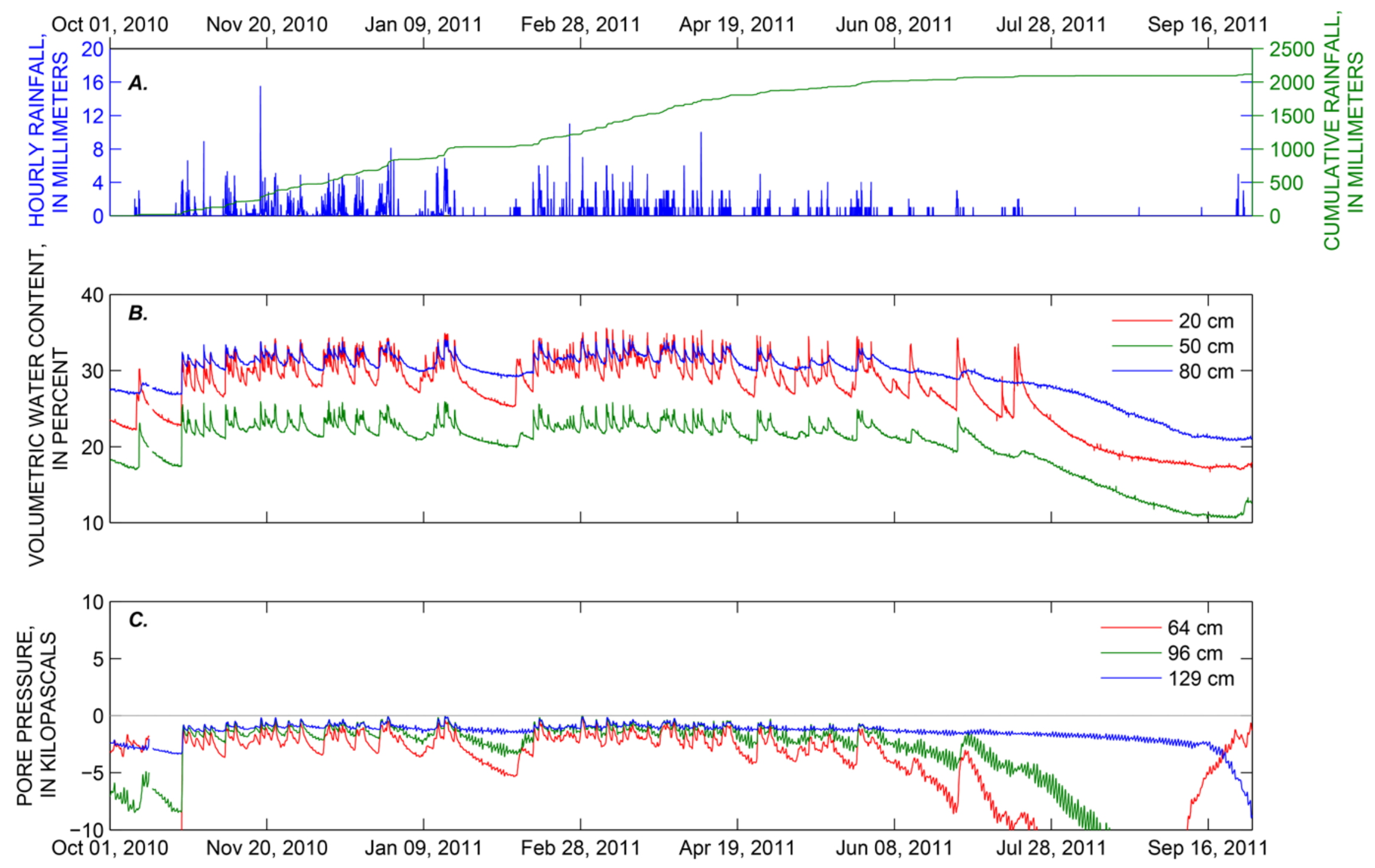

Figure 26. Hourly rainfall $A$, volumetric water content $B$, and pore pressure $C$ at Soil Pit 8 for HY2011. (HY, Hydrologic Year; $\mathrm{cm}$, centimeter 


\section{Hydrologic Year 2012}

Meteorological and hydrological trends in HY2012 were similar to those in the previous 2 years. The cumulative amount of rainfall recorded at the site was approximately 2,250 mm (figs. 27-34), exceeding that of both HY2011 (about 2,100 mm, figs. 11-18) and HY2010 (about 1,900 mm, figs. 1926), despite a several week dry period in early December.

Four significant rainfall events occurred during HY2012, each resulting in positive pore pressure in a representative sample of tensiometer readings. Some of the tensiometers showed transient periods of positive pore pressure that ranged from 8 to 28 hours in duration following major rainstorms. The most prominent event can be seen in figure $27 \mathrm{on} \mathrm{hr} 18$ and 19 where positive pore pressures at SP1 were recorded for $28 \mathrm{hr}$ beginning at 4:00 PST on the morning of January 18. Positive pore pressures corresponding to this event were also recorded by sensors in SP4, SP5, SP6, SP7, and SP8 (figs. 30-34). The large magnitude of the pore pressures (nearly $2 \mathrm{kPa}$ at SP5's tensiometer at $247 \mathrm{~cm}$, fig. 31) resulting from this storm can be linked to a previous storm that also produced large-magnitude positive pore pressures. The previous storm occurred on approximately December 28, and caused positive pore pressures at SP4, SP5, SP6, and SP7 (figs. 30-33). The third significant event occurred during March, when pore pressures at SP5 were positive for $26 \mathrm{hr}$ beginning on March 29 at 20:00 hours PST (fig. 31). Positive pressures were also seen at SP6, SP7, and SP8 (figs. 32-34). Two weeks previous, during a rainfall event on March 15, the same tensiometer at $247 \mathrm{~cm}$ below the ground surface near SP5 showed positive pore pressures beginning at 18:00 PST and sustained positive pressures for $9 \mathrm{hr}$ (fig. 31). 

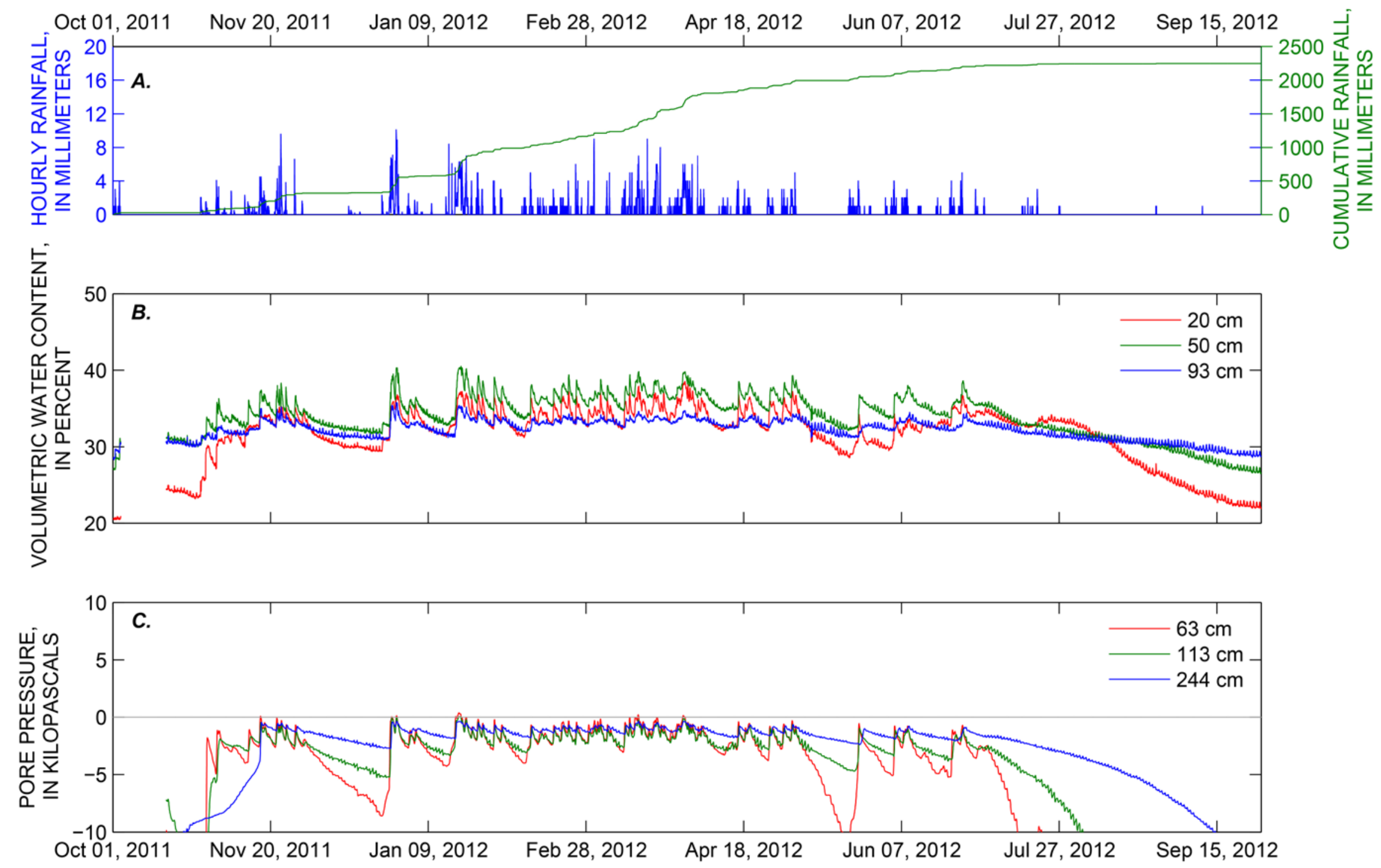

Figure 27. Hourly rainfall $A$, volumetric water content $B$, and pore pressure $C$ at Soil Pit 1 for HY2012. (HY, Hydrologic Year; cm, centimeters) 

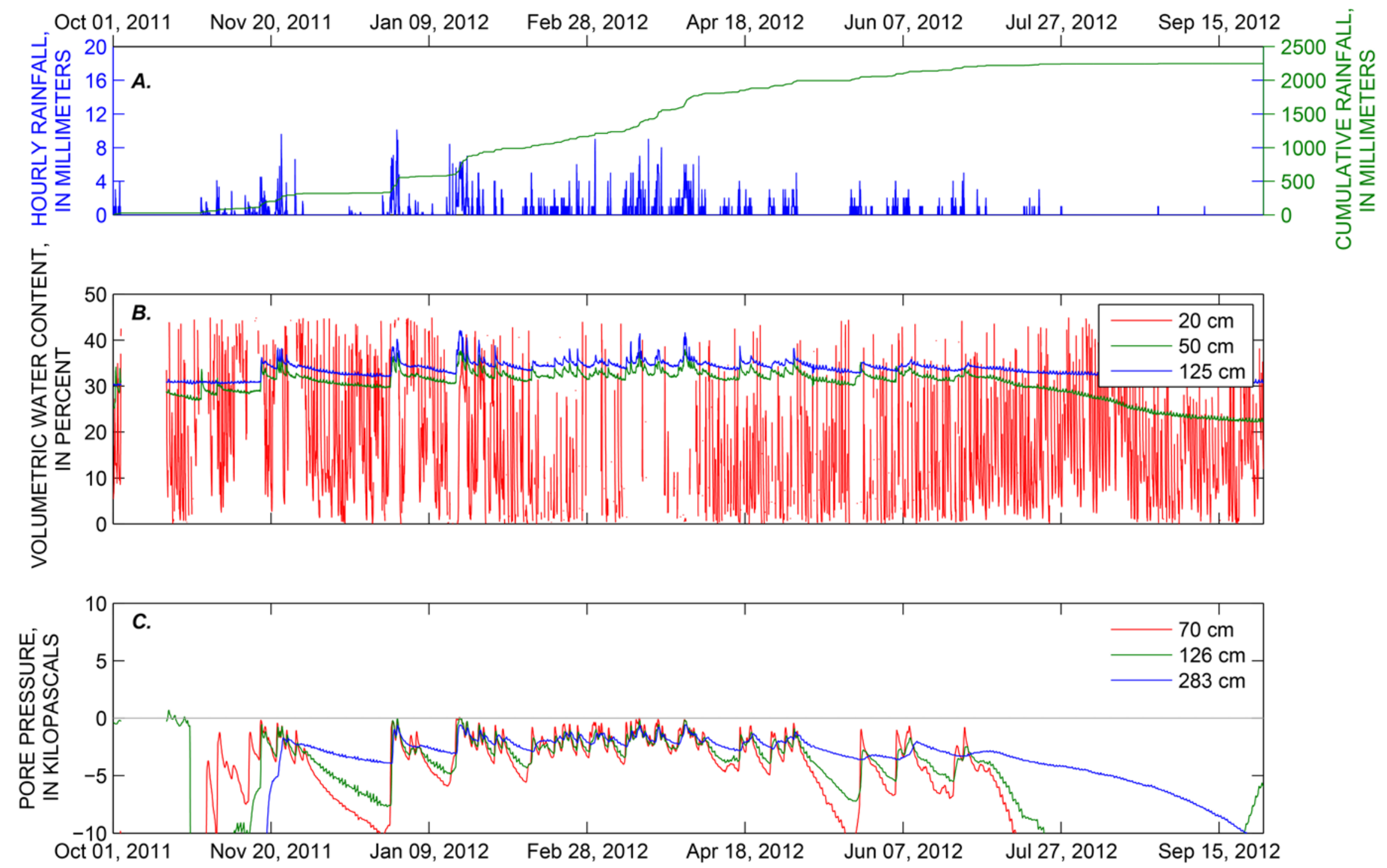

Figure 28. Hourly rainfall $A$, volumetric water content $B$, and pore pressure $C$ at Soil Pit 2 for HY2012. (HY, Hydrologic Year; cm, centimeters) 

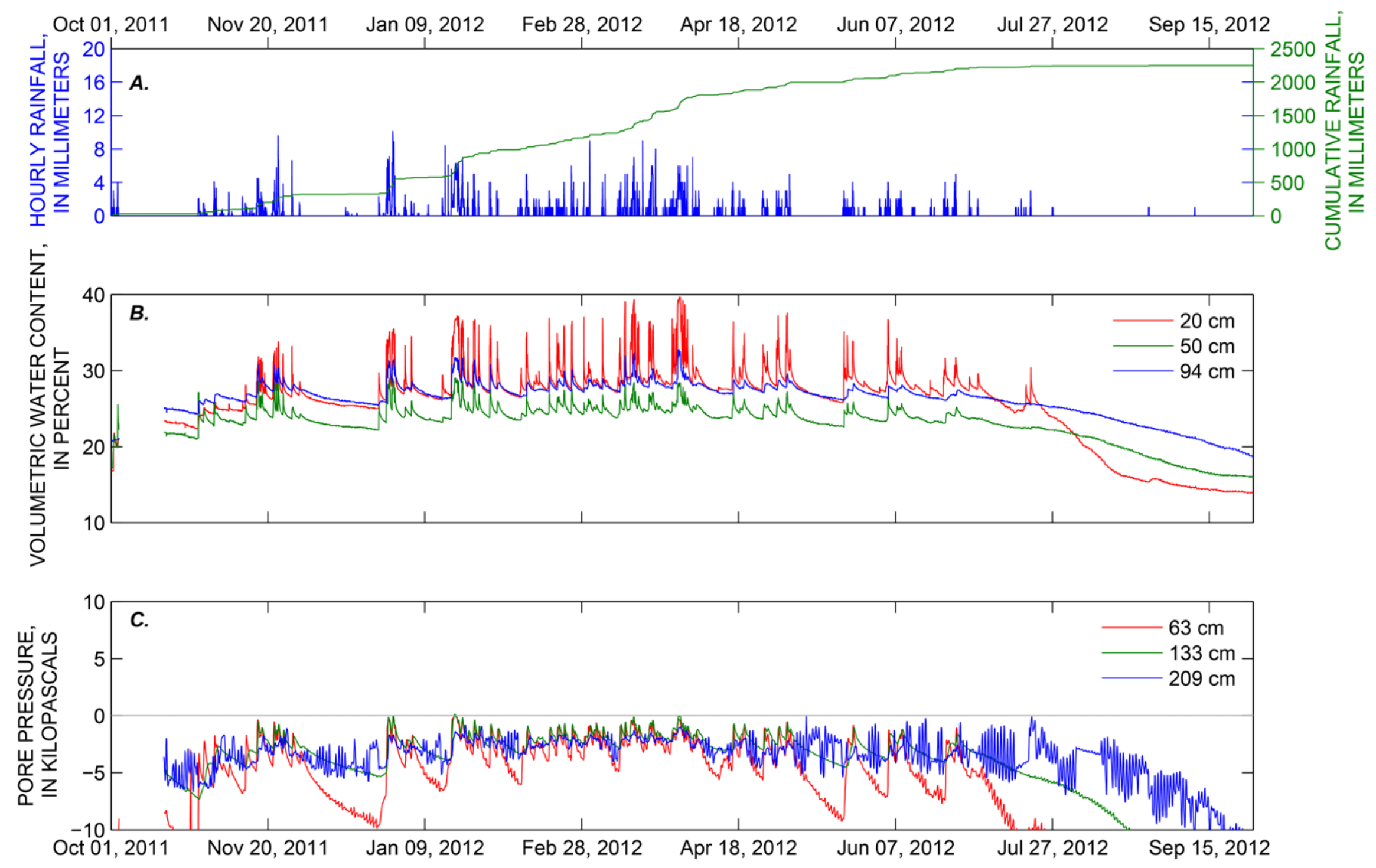

Figure 29. Hourly rainfall $A$, volumetric water content $B$, and pore pressure $C$ at Soil Pit 3 for HY2012. (HY, Hydrologic Year; cm, centimeters) 

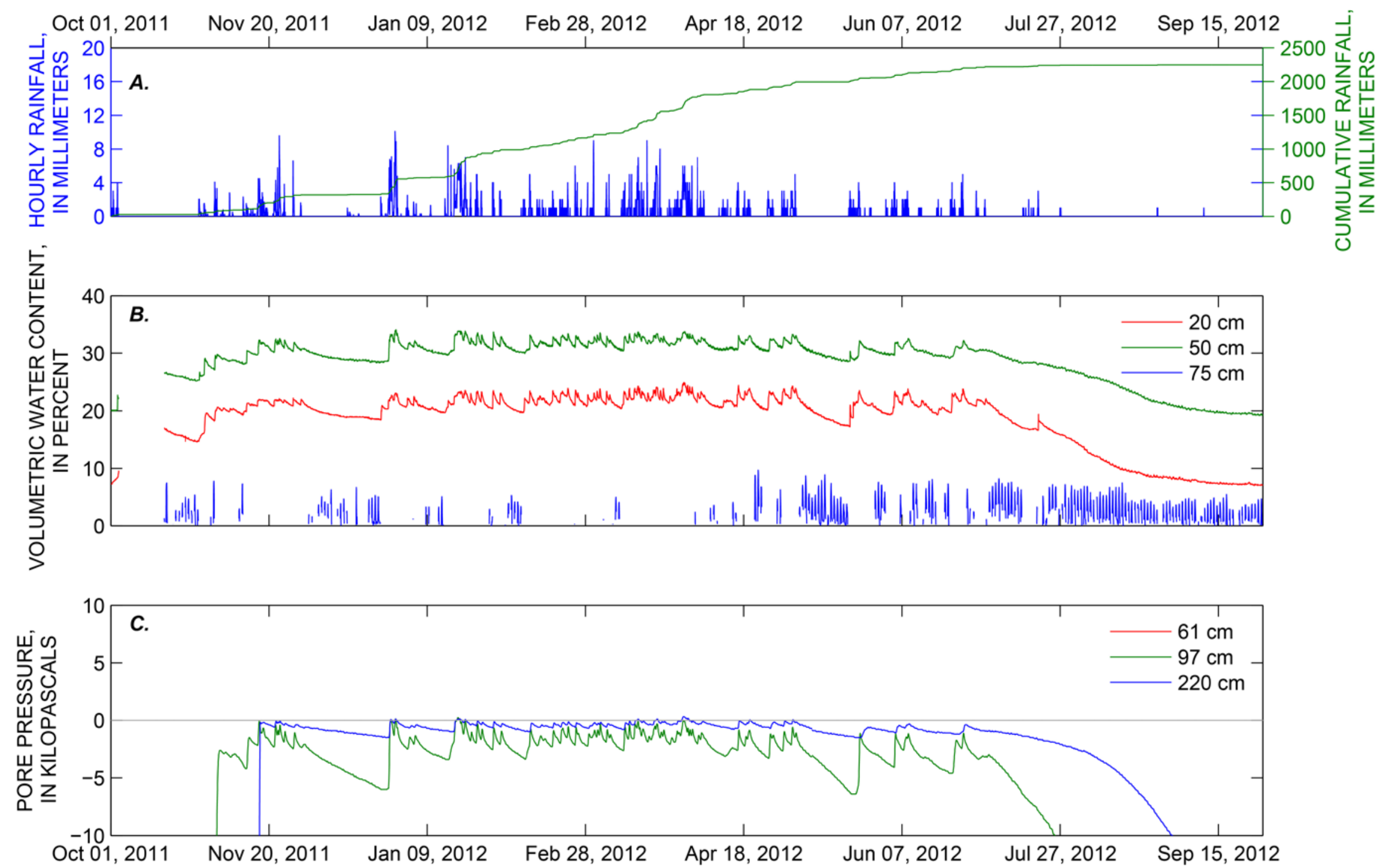

Figure 30. Hourly rainfall $A$, volumetric water content $B$, and pore pressure $C$ at Soil Pit 4 for HY2012. (HY, Hydrologic Year; $\mathrm{cm}$, centimeters) 

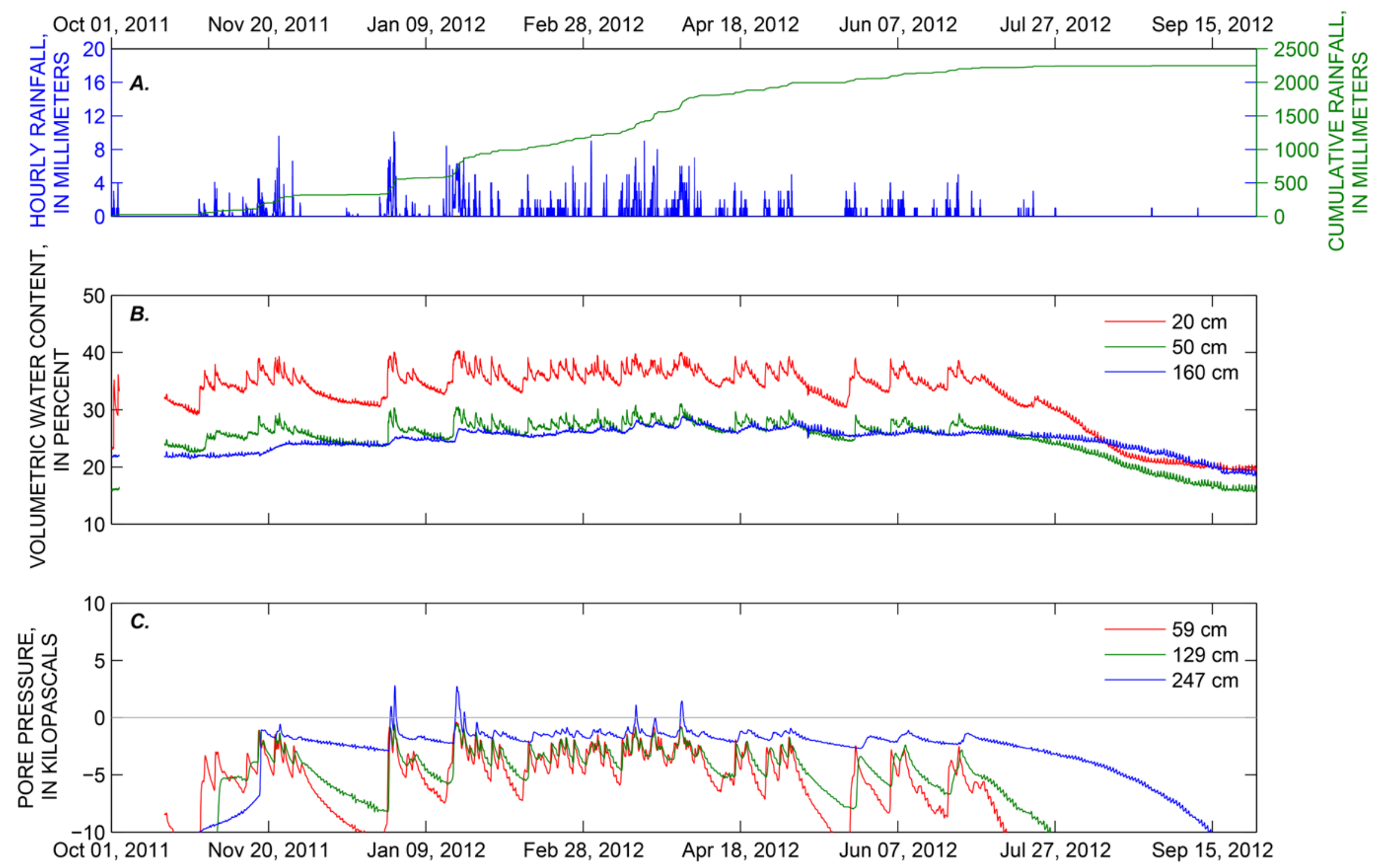

Figure 31. Hourly rainfall $A$, volumetric water content $B$, and pore pressure $C$ at Soil Pit 5 for HY2012. (HY, Hydrologic Year; cm, centimeters) 

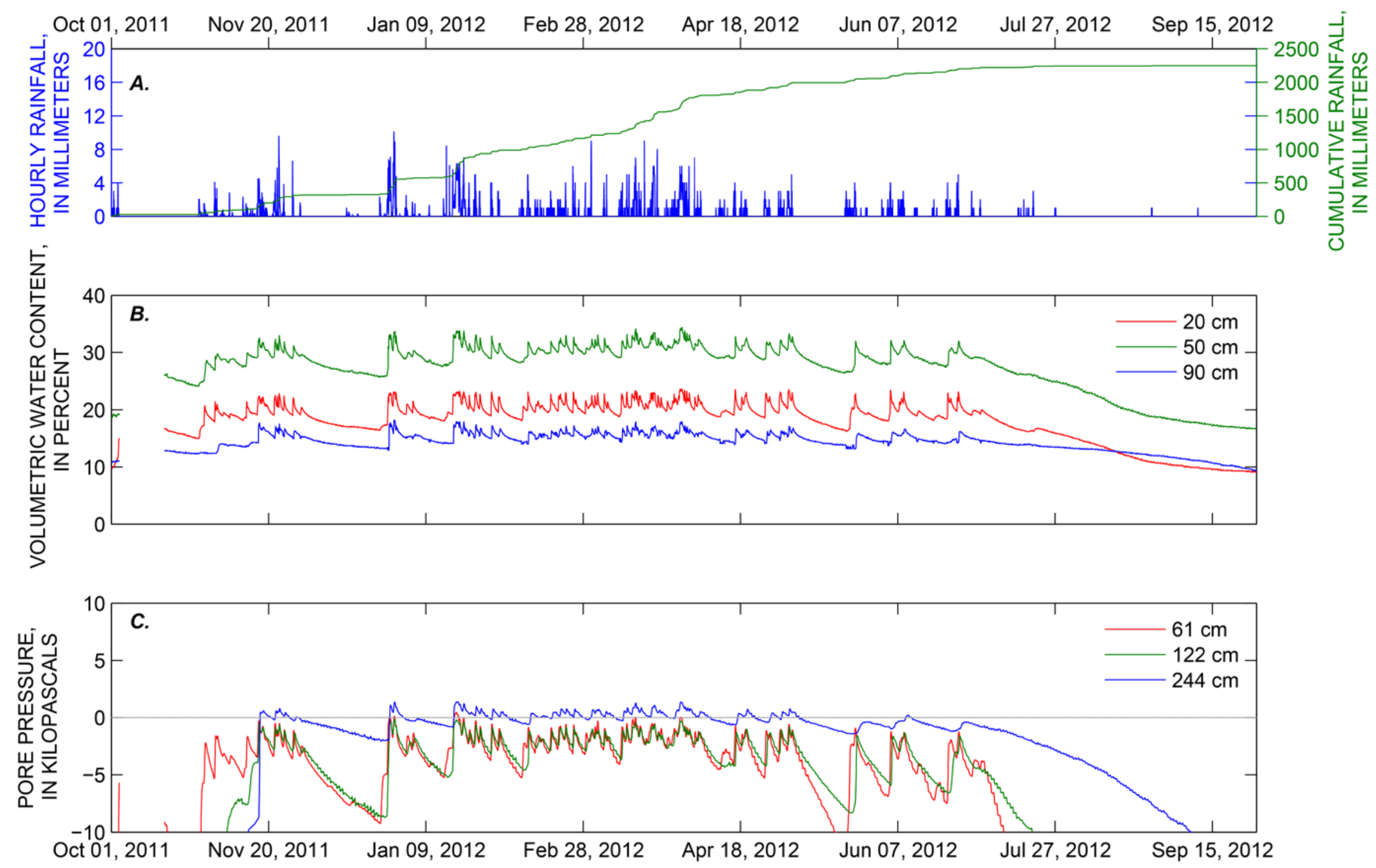

Figure 32. Hourly rainfall $A$, volumetric water content $B$, and pore pressure $C$ at Soil Pit 6 for HY2012. (HY, Hydrologic Year; cm, centimeters) 

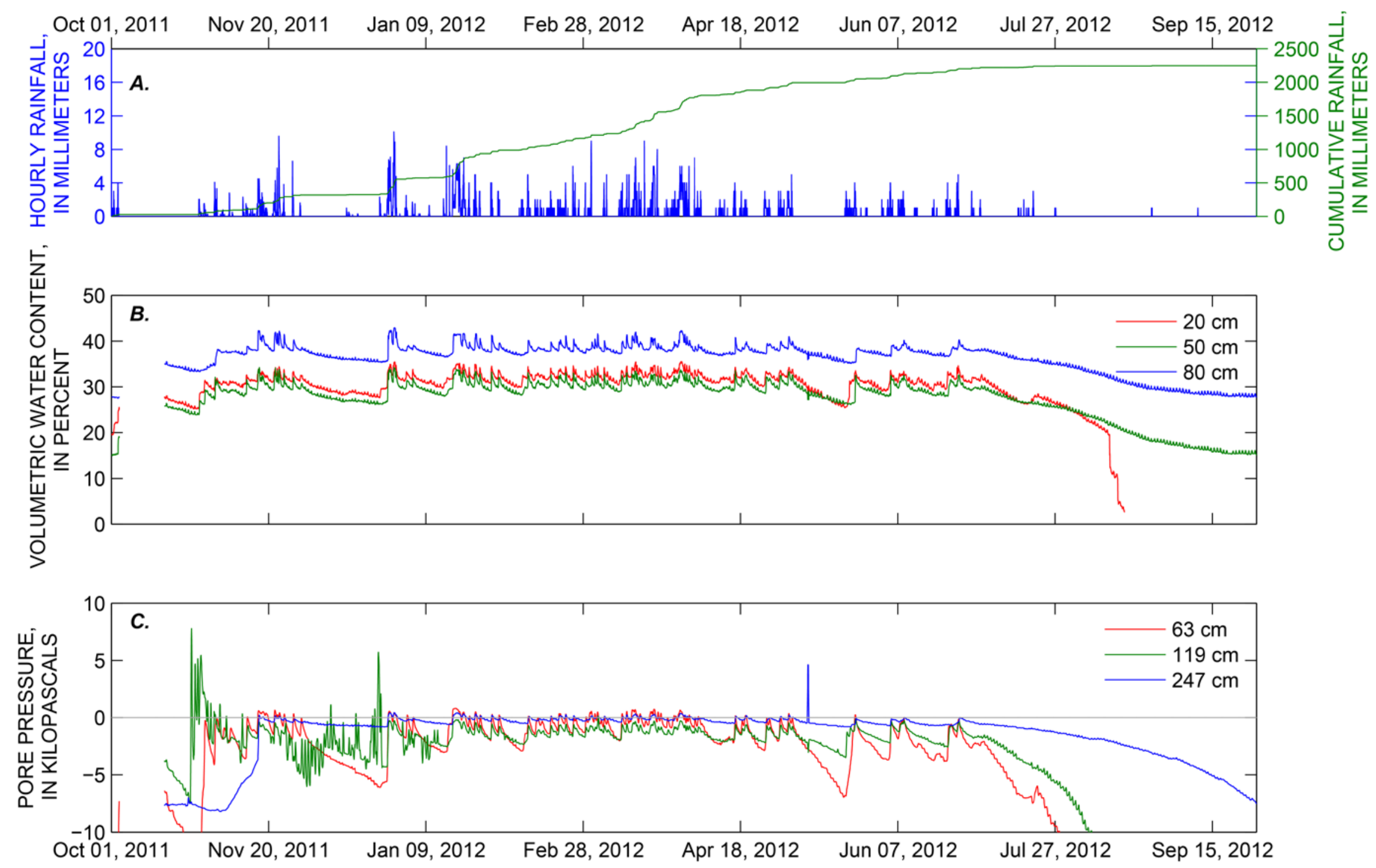

Figure 33. Hourly rainfall $A$, volumetric water content $B$, and pore pressure $C$ at Soil Pit 7 for HY2012. (HY, Hydrologic Year; $c m$, centimeters) 

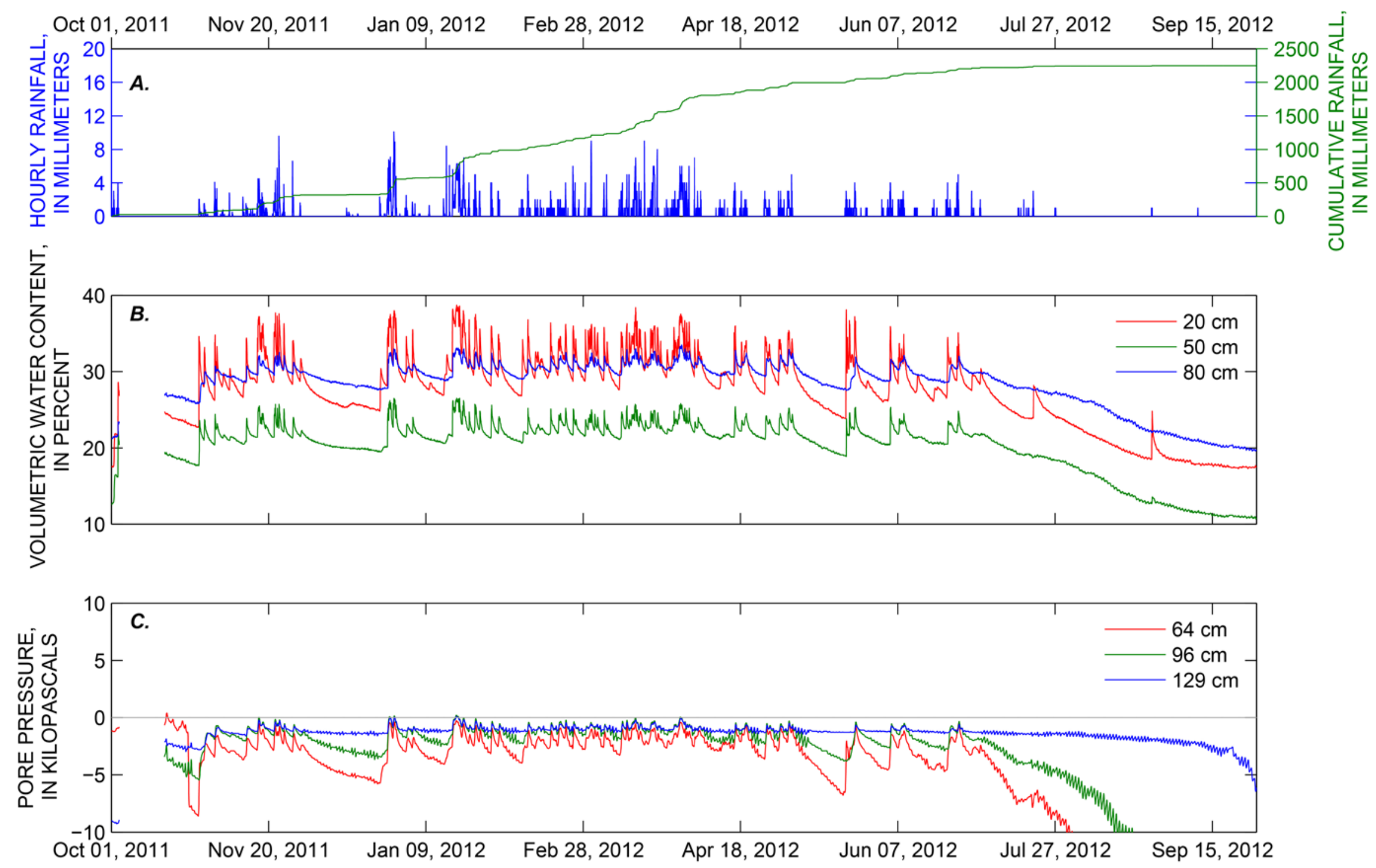

Figure 34. Hourly rainfall $A$, volumetric water content $B$, and pore pressure $C$ at Soil Pit 8 for HY2012. (HY, Hydrologic Year; cm, centimeters) 


\section{Vibrating Wire Piezometers}

The piezometer data stream became active around the first week of November 2009, but is especially noisy due to the charging system, even after filtering the data. Though the piezometer data stream gives a good trend of water level heights within the catchment axis, transient response to rainfall cannot be confidently discerned from signal noise (figs. 35-37). 

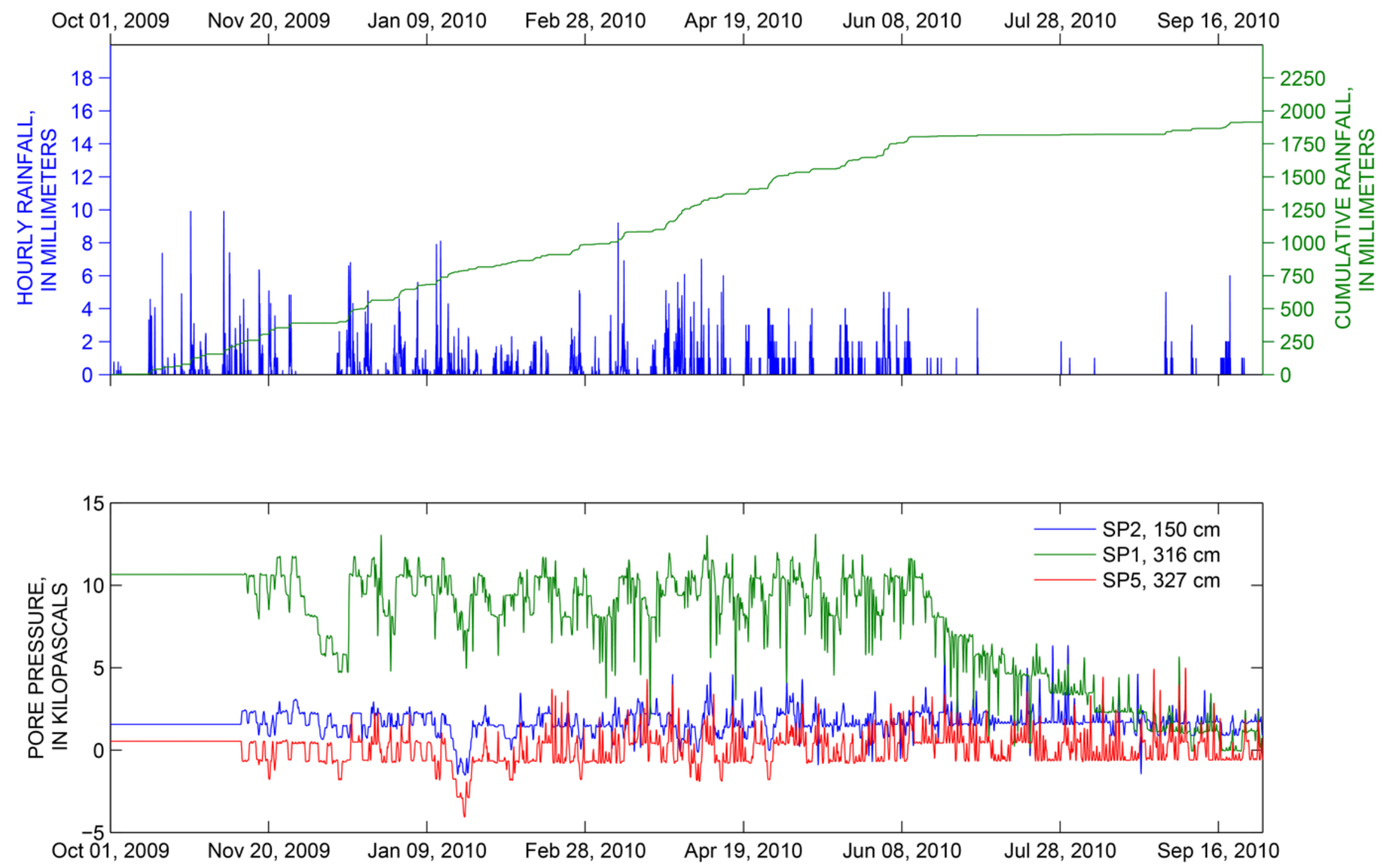

Figure 35. Hourly rainfall and pore pressure along basin axis for HY2010. (cm, centimeters) 

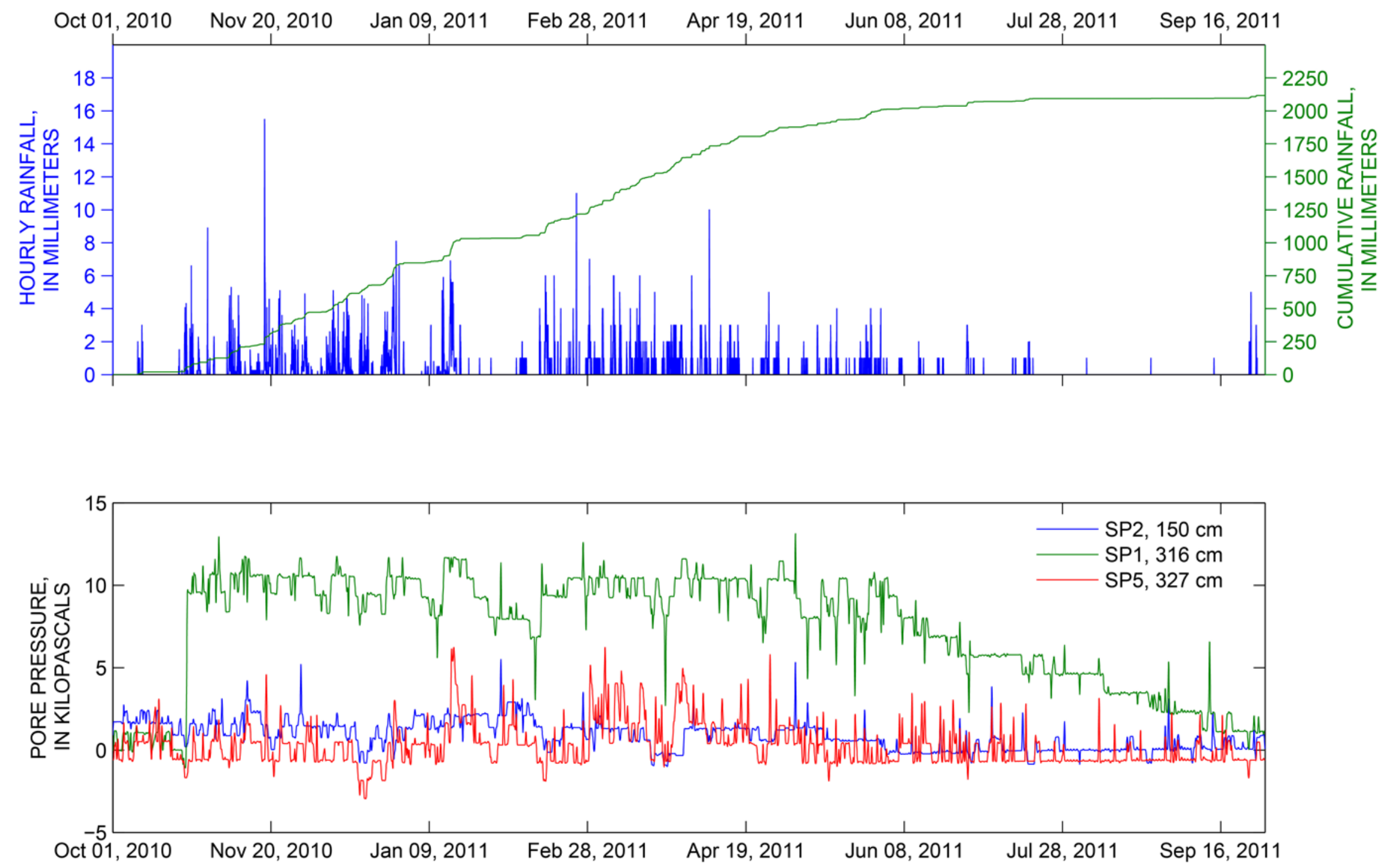

Figure 36. Hourly rainfall and pore pressure along basin axis for HY2011. (cm, centimeters) 

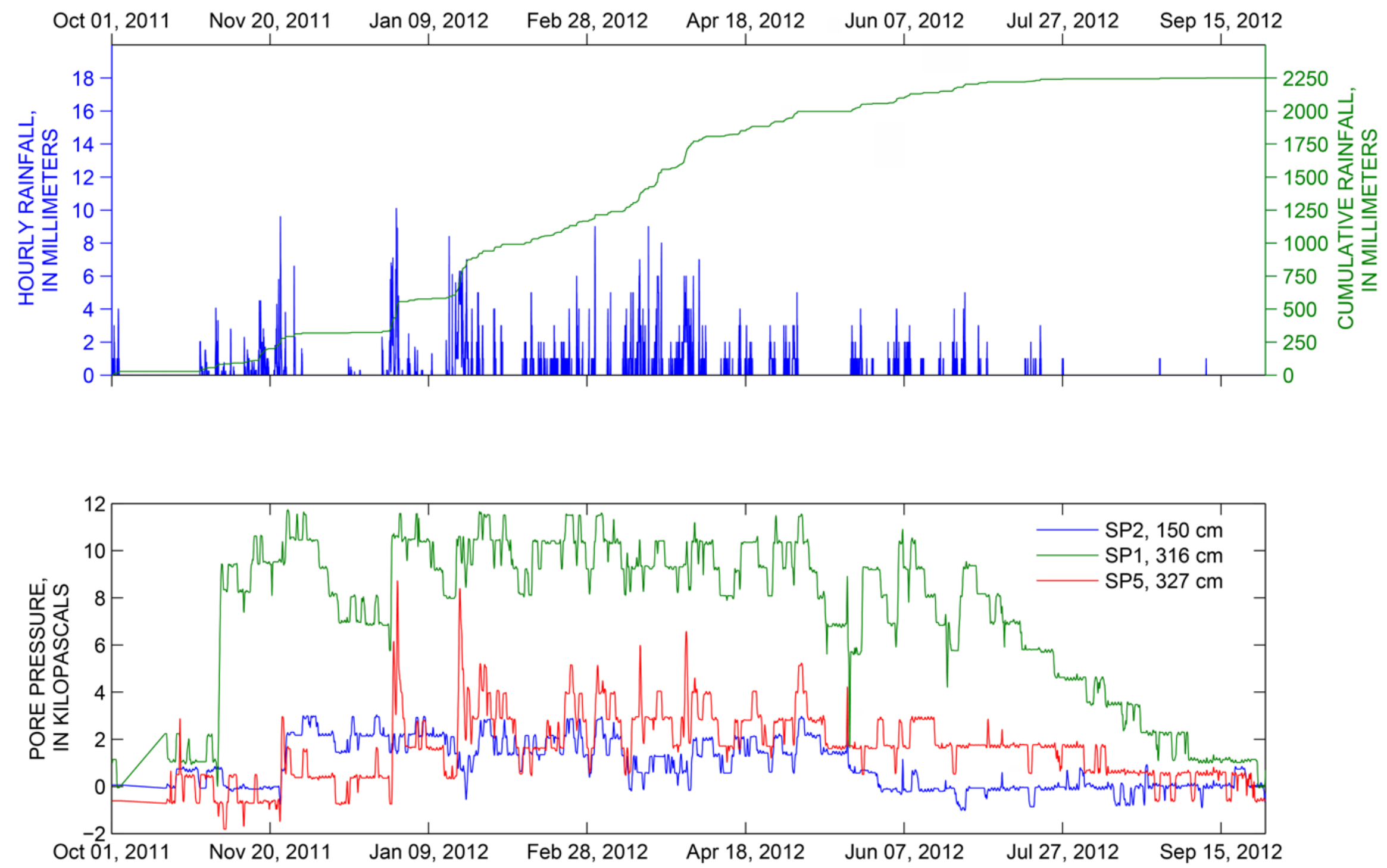

Figure 37. Hourly rainfall and pore pressure along basin axis for HY2012. (cm, centimeters) 


\section{Inclinometers}

Figure 38 shows data plots from three biaxial inclinometers located near SP1 (fig. 38A), SP2 (fig. 38B), and SP7 (fig. 38C). This chart graphically suggests that no appreciable landslide movement occurred near the instruments, which was verified during site visits. However, some degree of tilt, approximately $0.025^{\circ}$ in the $\mathrm{x}$-axis and $0.035^{\circ}$ in the y-axis, can be seen in the instrument located near SP2 (fig. 38B). Since the inclinometer is located within casing (assumed to be rigid) inserted to one meter, projecting the tilt to the surface of the slope results in displacement of about $1 \mathrm{~mm}$, or $0.3 \mathrm{~mm} / \mathrm{yr}$ (millimeters per year) assuming no movement occurred below instrument depth. An example of what was determined to be a temperature response, possibly frost heave, can be seen in SP1 inclinometer data during January 2011 (fig. 38A). The built in thermistor in the sensor, which was used for a temperature correction, read freezing temperatures for the short 8-hr period when the instrument shifted. 

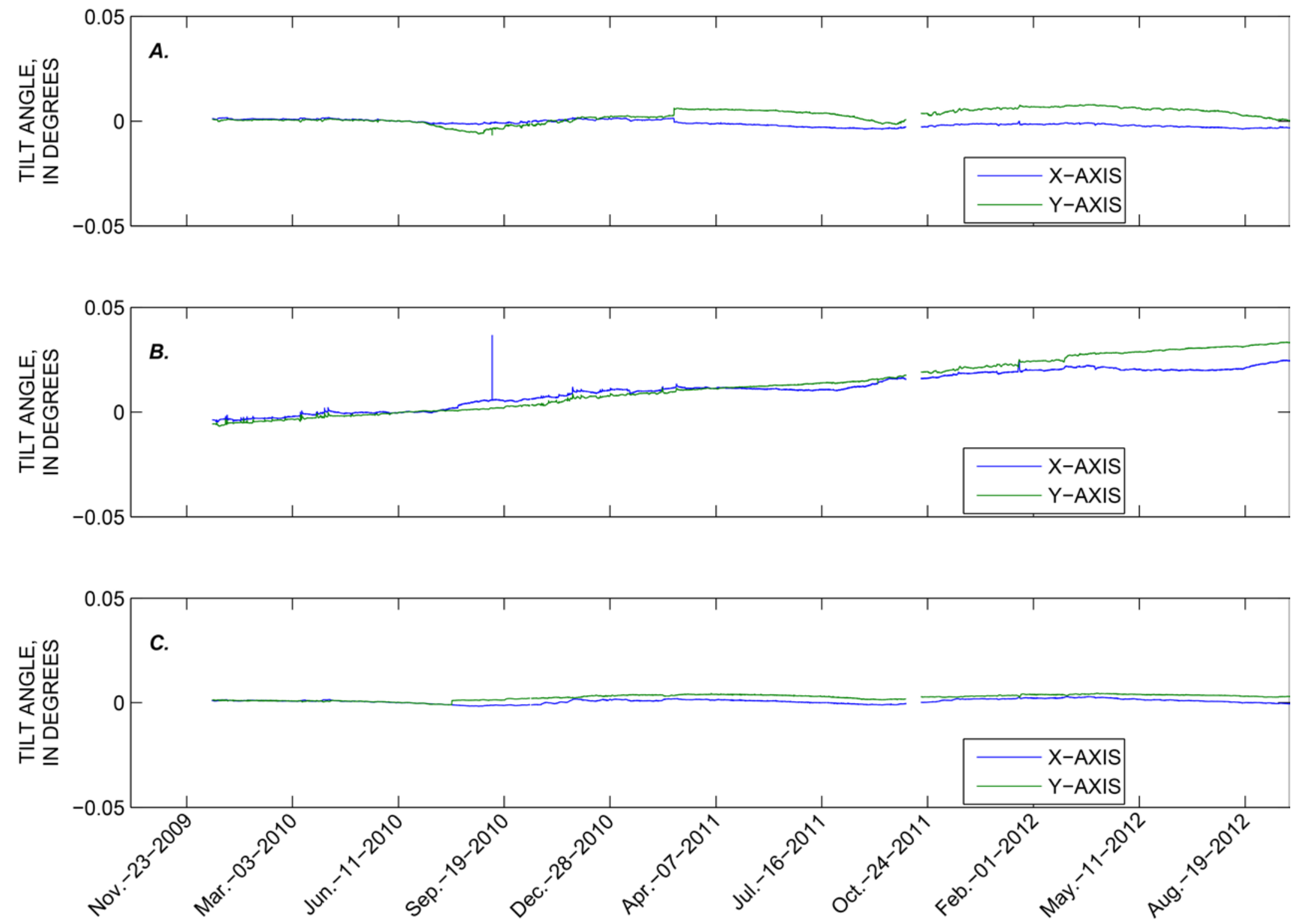

Figure 38. Inclinometer tilt measurement plots from $A, \mathrm{SP} 1 ; B, \mathrm{SP} 2$; and $C, \mathrm{SP} 7$. 


\section{Summary}

Our monitoring data for the entire 3-yr period show that soil pore pressure and volumetric water content increase in response to the onset of rainfall and maintain high levels throughout the wet season. Soil pore pressure and volumetric water content decrease at the beginning of the dry season, and dry conditions persist until the onset of the following wet season. Figures 39 and 40 show the spatial and seasonal variation in pore pressure and volumetric water content, respectively. Each boxplot shows a box that denotes the interquartile range (IQR) between the 25th and 75th percentiles, upper and lower "whiskers" that show the most extreme data points within 1.5 IQR of the upper or lower quartiles, the median (shown graphically with a red line, and numerically), and outliers (markers along vertical axis). The plot shows data from multiple soil pits separated into various depth categories (shallow, mid, and deep) and grouped for specific areas on the slope (basin axis, side slope, and nose slope). Basin axis data comes from SP1, SP2, and SP5, side slope data from SP7 and SP8, and nose slope data from SP3, SP4, and SP6.

Pore pressure and volumetric water-content data were grouped into wet and dry seasons that varied in start date and duration based on each Hydrologic Year's rainfall characteristics. Plots in figures 39 and 40 show statistics for wet seasons and dry seasons. The range and duration of wet and dry seasons were chosen from the rainfall data; the start and end dates of the wet season were subjectively defined by the year's first and last significant rainfall events. The start dates of each hydrologic year's wet season were chosen as December 1, 2009; October 24, 2010; and October 28, 2011. The start dates of the dry seasons were chosen to be June 10, 2010; June 1, 2011; and June 6, 2012. Modification of tensiometer datasets during dry seasons was necessary because the sensors do not provide accurate readings after prolonged dry periods (see "Methods" section). The dataset was clipped as the porepressure readings increased without apparent soil moisture increase. This report includes complete data for December 1, 2009 through September 30, 2012; thus, the first wet season and final dry season datasets were truncated. Furthermore, data from noisy sensors (see System Reliability) are not included in these plots. 

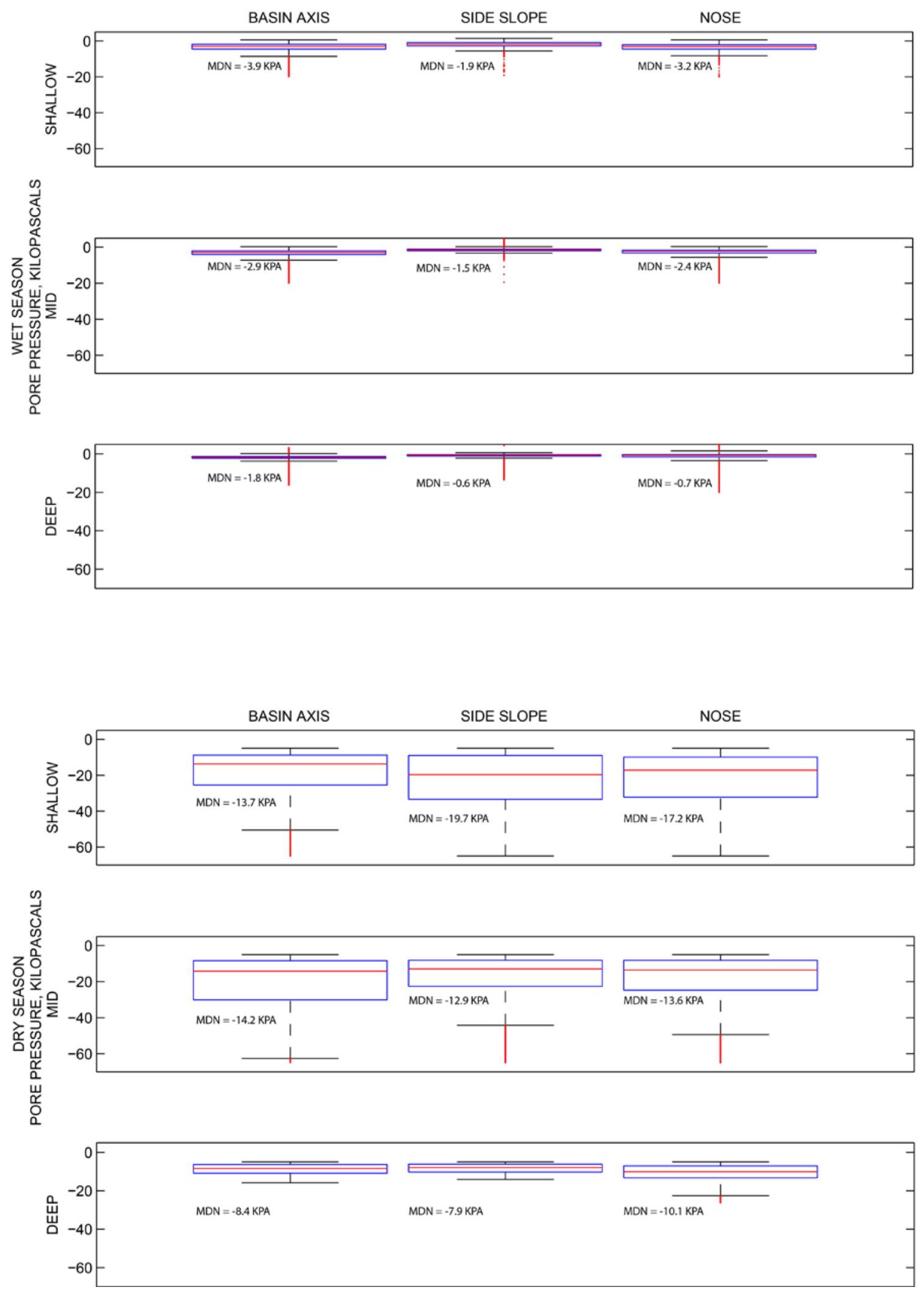

Figure 39. Boxplots showing seasonal and topographic variation in pore pressure/soil suction measurements. (MDN, median; KPA, kilopascals) 

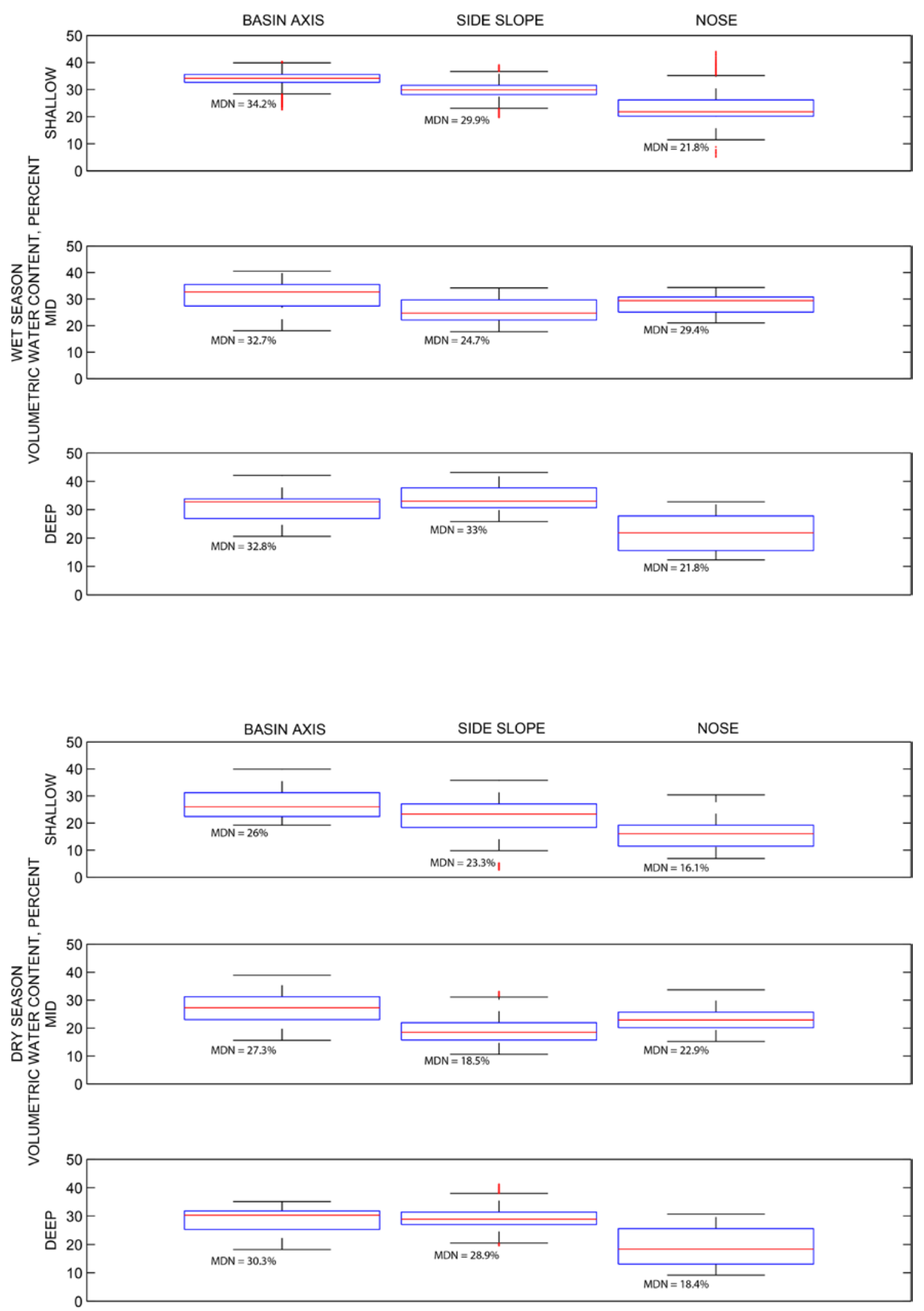

Figure 40. Boxplots showing seasonal and topographic volumetric water-content variation. (MDN, median) 
Compilation of $3 \mathrm{yr}$ of pore-pressure data shows that basin location, depth beneath the ground surface, depth to bedrock, and existing hydrologic conditions have bearing on pore-pressure response to rainfall. Figure 39 shows the seasonal and topographic variability of pore pressure measured by 24 tensiometers located throughout the monitoring basin. The wet season portion of the graph shows a proportional relationship between depth and pore pressure; that is, deeper sensors generally have greater pore pressures. Furthermore, figures 11-34 show that, in general, lag time in response to rainfall and drought are proportional to sensor depth; that is, as sensor depth increases so does the time it takes for its pore-pressure reading to respond to a rainfall event. Pore pressures are apparently correlated with topographical location within the basin and are generally the highest at the side slope, followed by the basin axis, and finally the nose slope. This relationship may result from the proximity of the sensor tip to the bedrock, based on the shallower depth to bedrock in the side slope and nose slope than in the basin axis. The dry season plots show a similar trend in median values (fig. 39) where pore pressure varies proportionally with depth (with exception of the mid-depth basin axis data).

Our results show that, on average, the seasonal variation in volumetric water content is twice as large for the shallow sensors as for the deep sensors. Figure 40 shows the seasonal and topographic variability in volumetric water content within nine groups of volumetric water-content sensors representing the shallow, mid, and deep depths along the basin axis, side slope, and nose slope. In general, the data show that deeper soil is more resistant to seasonal moisture content variation. Deeper soil averages a change of 3.3 percent between dry and wet seasons. By comparison, the shallowest soil depth data show seasonal variation is about 6.8 percent volumetric water content. The volumetric watercontent data show, on average, that the axis of the basin is the wettest location, followed by the side slope, and finally the nose slope.

\section{Acknowledgments}

John Seward and Norma Kline of the Oregon Department of Forestry facilitated access to the monitoring site. Raymond Surprenant and Andrew Ashlock provided assistance in equipment installation. Joshua Theule assisted with fieldwork. Reviews by Francis Ashland and William Schulz improved the clarity and completeness of the manuscript.

\section{References Cited}

Andrus, C., Bahus, K., Craig, K., Runyon, J., Schwindt, and R., Souder, J., 2003, Elliott State Forest watershed analysis: Oregon Department of Forestry, 288 p., accessed March 1, 2012 at http://www.oregon.gov/odf/state_forests/docs/watershed/esf_watershed_analysis/300_elliott_wa_enti re final_report.pdf.

Baldwin, E.M., 1961, Geologic map of the lower Umpqua River area, Oregon: U.S. Geological Survey Oil and Gas Investigations Map, OM-204, scale 1:62,500.

Baum, R.L., McKenna, J.P., Godt, J.W., Harp, E.L, and McMullen, S.R., 2005, Hydrologic monitoring of landslide-prone coastal bluffs near Edmonds and Everett, Washington, 2001-2004: U.S. Geological Survey Open-File Report 2005-1063, 42 p.

Beaulieu, J.D., and Hughes, P.W., 1975, Environmental geology of western Coos and Douglas Counties, Oregon: Oregon Department of Geology and Mineral Industries Bulletin, 87, 148 p.

Beier, P., 1989, Use of habitat by mountain beaver in the Sierra Nevada: Journal of Wildlife Management, v. 53, no. 3, p. 649-654.

Beschta, R.L., 1978, Long-term patterns of sediment production following road construction and logging in the Oregon Coast Range: Water Resources Research, v. 14, no. 6, p. 1011-1016. 
Birkeland, P.W., 1999, Soils and geomorphology (3d ed): New York, Oxford University Press, 430 p.

Bransom, M., 1990, Soil engineering properties and vegetative characteristics for headwall slope stability analysis in the Oregon Coast Range: Corvallis, Oreg., Oregon State University, Master's Thesis, $91 \mathrm{p}$.

Brown, G.W., and Krygier, J.T., 1971, Clear-cut logging and sediment production in the Oregon Coast Range, Water Resources Research, v. 7, no. 5., p. 1189-1198.

Burroughs, E.R., and Thomas, B.R., 1977, Declining root strength in Douglas-fir after felling as a factor in slope stability: U.S. Department of Agriculture Forest Service Research Paper INT-190, 27 p.

Coe, J.A., Michael, J.A., and Burgos, M.M., 2011, Map of debris flows caused by rainfall during 1996 in parts of the Reedsport and Deer Head Point Quadrangles, Douglas County, Southern Coast Range, Oregon: U.S. Geological Survey Open-File Report 2011-1150, 9 p., 1 map sheet, at http://pubs.usgs.gov/of/2011/1150/.

Dietrich, W.E., and Dunne, T., 1978, Sediment budget for a small catchment in mountainous terrain: Zeitschrift für Geomorphologie, supplementary v. 29, p. 191-206.

Godt, J.W., Baum, R.L., and Lu, N., 2009, Landsliding in partially saturated materials: Geophysical Research Letters, v. 36, no. 2, 5 p.

Gustafsson, F., 1996, Determining the initial state in forward-backward filtering: IEEE Transactions on Signal Processing, v. 44, no. 4, p. 988-992.

Hack, J.T., and Goodlett, J.C., 1960, Geomorphology and forest ecology of a mountain region in the central Appalachians: U.S. Geological Survey Professional Paper 347, 64 p.

Harr, R.D., and Yee, C.S., 1975, Soil and hydrologic factors affecting the stability of natural slopes in the Oregon Coast Range: Corvallis, Oreg., Water Resources Research Institute, WRRI-33, 210 p.

Heimsath, A.M., Deitrich, W.E., Nishiizumi, K., and Finkel, R.C., 2001, Stochastic processes of soil production and transport: erosion rates, topographic variation and cosmogenic nuclides in the Oregon Coast Range: Earth Surface Processes and Landforms, v. 26, no. 5, p. 531-552.

Heller, P.L. and Dickinson, W.R., 1985, Submarine ramp facies model for delta-fed, sand-rich turbidite systems: American Association of Petroleum Geologists Bulletin, v. 69, p. 960-976.

Johnson, D.R., Haagen, J.T., Terrell, A.C., 1994, Soil survey of Douglas County area, Oregon: U.S. Department of Agriculture, Natural Resources Conservation Service, 935 p.

Keim, R.F., and Skaugset, A.E., 2003, Modelling effects of forest canopies on slope stability: Hydrological Processes, v. 17, p. 1457-1467.

Kelsey, H.M., Ticknor, R.L., Bockheim, J.G., and Mitchell, C.E., 1996, Quaternary upper plate deformation in coastal Oregon: Geological Society of America Bulletin, v. 108, p. 834-860.

Kizito, F., Campbell, C.S., Campbell, G.S., Cobos, D.R., Teare, B.L., Carter, B., and Hopmans, J. W., 2008, Frequency, electrical conductivity, and temperature analysis of a low-cost capacitance soil moisture sensor: Journal of Hydrology, v. 352, p. 367-378.

Lane, J.W., 1987, Relations between geology and mass movement features in a part of the East Fork Coquille River Watershed, Southern Coast Range, Oregon: Corvallis, Oreg., Oregon State University, Master's Thesis, $119 \mathrm{p}$.

Molenaar, C.M., 1985, Depositional relations of Umpqua and Tyee Formations (Eocene), southwestern Oregon: American Association of Petroleum Geologists Bulletin, v. 69, no. 8, p. 1217-1229.

Montgomery, D.R., Schmidt, K.M., Dietrich, W.E., and McKean, J., 2009, Instrumental record of debris flow initiation during natural rainfall-Implications for modeling slope stability: Journal of Geophysical Research, v. 114, F01031, 16 p. 
Niem, A.R., and Niem, W.A., 1990, Explanation of the geologic units for the compilation geologic map of the Southern Tyee Basin, Southern Coast Range, Oregon: Oregon Department of Geology and Mineral Industries Open-File Report 0-89-3, 44 p., 3 pl.

Oppenhiem, A.V., and Schafer, R.W., 1989, Discrete-time signal processing: Upper Saddle River, N.J., Prentice-Hall, p. 284-285.

Patric, J.H., and Swanston, D.N., 1968, Hydrology of a slide-prone glacial till soil in southeast Alaska: Journal of Forestry, v. 66, p. 62-66.

Personius, S.F., 1995, Late Quaternary stream incision and uplift in the forearc of the Cascadia subduction zone, western Oregon: Journal of Geophysical Research, v. 100, p. 20,193-20,210.

Pierson, T.C., 1980, Piezometric response to rainstorms in forested hillslope drainage depressions: Journal of Hydrology (New Zealand), v. 19, no. 1, 10 p.

Reid, M.E., Baum, R.L., LaHusen, R.G., and Ellis, W.L., 2008, Capturing landslide dynamics and hydrologic triggers using near-real-time monitoring: in Chen, Z., Zhang, J., Li, Z., Wu, F., Ho, K., eds., Landslides and engineered slopes: London, Taylor and Francis Group, p. 179-191.

Reneau, S.L., Dietrich, W.E., 1991, Erosion rates in the Southern Oregon Coast Range-Evidence for an equilibrium between hillsope erosion and sediment yield: Earth Surface Processes and Landforms, vol. 16, p. 307-322.

Robison, E.G., Mills , K.A., Paul, J., Dent, L., and Skaugset, A.E., 1999, Storm impacts and landslides of 1996-Final report: Oregon Department of Forestry, Forestry Practices Technical Report no. 4, $145 \mathrm{p}$.

Roering, J.J., Kirchner, J.W., and Dietrich, W.E., 1999, Evidence for nonlinear, diffusive sediment transport on hillslopes and implications for landscape morphology: Water Resources Research, v. 35, no. 3, p. 853-870.

Roering, J.J., Schmidt, K.M., Stock, J.D., Dietrich, W.E., Montgomery, D.R., 2003, Shallow landsliding, root reinformcement, and the spatial distribution of trees in the Oregon Coast Range, Canadian Geotechnical Journal, v. 40, p. 237-253.

Schaefer, G.L., 1990, SNOTEL-The world's first and largest data collection system using meteor burst technology, in Shamir, U., and Jiaqi, Chen, eds., The hydrological basis for Water Resources Management: Wallingford, UK, IAHS Press, p. 229-238. [Proceedings of the International Symposium held at Beijing, China, October 23-26, 1990]

Schmidt, K.M., Roering, J.J., Stock, J.D., Dietrich, W.E., Montgomery, D.R., and Schaub, T., 2001, The variability of root cohesion as an influence on shallow landslide susceptibility in the Oregon Coast Range: Canadian Geotechnical Journal, v. 38, p. 995-1024.

Soil Survey Staff, 2013, Web soil survey: U.S. Department of Agriculture, Natural Resources Conservation Service, accessed on March 12, 2013, at http://websoilsurvey.nrcs.usda.gov/.

Swanson, F.J., Swanson, M.M., and Woods, C.W., 1981, Analysis of debris-avalanche erosion in steep forest lands-An example from Mapleton, Oregon, USA, in Davies, Pearce, eds., Erosion and sediment transport in Pacific Rim Steeplands: Washington, D.C., International Association of Hydrological Sciences, no. 132, p.67-75. [Proceedings of the Christchurch Symposium, New Zealand, January 1981]

Swanston, D.N., 1970, Mechanics of debris avalanching in shallow till soils of southeast Alaska: U.S. Department of Agriculture, Forest Service Research Paper PNW-103, 17 p.

Torres, R., Dietrich, W.E., Montgomery, D.R., Anderson, S.P., and Loague, K., 1998, Unsaturated zone processes and the hydrologic response of a steep, unchanneled catchment: Water Resources Research, v. 34, no. 8, p. 1865-1879. 
Tsukamoto, Y., Ohta, T., and Noguchi, H., 1982, Hydrological and geomorphological studies of debris slides on forested hillslopes in Japan, in Walling, D.E., ed., Recent developments in the explanation and prediction of erosion and sediment yield: International Association of Hydrological Sciences Publication, no. 137, p. 89-98.

Wells, R.E., Jayko, A.S, Niem, A.R., Black, G, Wiley, T, Baldwin, E., Molenaar, K.M., Wheeler, K.L, DuRoss, C.B., Givler, R.W., 2000, Geologic map and database of the Roseburg 30 x 60 minute quadrangle, Douglas and Coos Counties, Oregon: U.S. Geological Survey Open-File Report 00-376, 1 map sheet.

Wiley, T.J., 2000, Relationship between rainfall and debris flows in western Oregon: Oregon Geology, v. 62, no. 2, p. 27-43.

Young, A., Saunders, I., 1986, Rates of surface processes and denudation, in Abrahams, A.D., ed., Hillslope Processes: Boston, Mass., The Binghamton Symposia in Geomorphology, International Series, no.16, p. 3-27. 